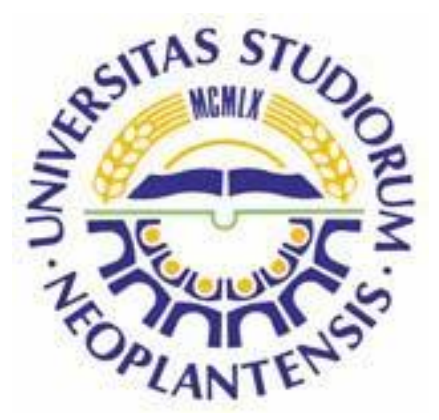

UNIVERZITET U NOVOM SADU

MEDICINSKI FAKULTET

DOKTORSKE STUDIJE KLINIČKE MEDICINE

\title{
OKSIDATIVNI STRES KOD PACIJENATA SA PARODONTOPATIJOM
}

\author{
DOKTORSKA DISERTACIJA
}

Mentor: Prof. dr Milanko Đurić

Kandidat: Asist. dr Tanja Predin

NOVI SAD, 2014 


\section{UNIVERZITET U NOVOM SADU MEDICINSKI FAKULTET}

\section{KLJUČNA DOKUMENTACIJSKA INFORMACIJA}

\begin{tabular}{|l|l|}
\hline Redni broj: & \\
RBR & \\
\hline $\begin{array}{l}\text { Identifikacioni broj: } \\
\text { IBR }\end{array}$ & \\
\hline $\begin{array}{l}\text { Tip dokumentacije: } \\
\text { TD }\end{array}$ & Monografska dokumentacija \\
\hline $\begin{array}{l}\text { Tip zapisa: } \\
\text { TZ }\end{array}$ & Tekstualni štampani materijal \\
\hline $\begin{array}{l}\text { Vrsta rada (dipl., mag., dokt.): } \\
\text { VR }\end{array}$ & Doktorska disertacija \\
\hline $\begin{array}{l}\text { Ime i prezime autora: } \\
\text { AU }\end{array}$ & Tanja Predin \\
\hline $\begin{array}{l}\text { Mentor (titula, ime, prezime, } \\
\text { zvanje): } \\
\text { MN }\end{array}$ & $\begin{array}{l}\text { Prof. dr Milanko Đurić, vanredni profesor } \\
\text { Naslov rada: } \\
\text { NR }\end{array}$ \\
\hline $\begin{array}{l}\text { Jezik publikacije: } \\
\text { JP }\end{array}$ & $\begin{array}{l}\text { Oksidativni stres kod pacijenata sa } \\
\text { parodontopatijom }\end{array}$ \\
\hline $\begin{array}{l}\text { Jezik izvoda: } \\
\text { JI }\end{array}$ & srpski (latinica) \\
\hline $\begin{array}{l}\text { Zemlja publikovanja: } \\
\text { ZP }\end{array}$ & srp. / eng. \\
\hline $\begin{array}{l}\text { Uže geografsko područje: } \\
\text { UGP }\end{array}$ & Republika Srbija \\
\hline $\begin{array}{l}\text { Godina: } \\
\text { GO }\end{array}$ & Vojvodina \\
\hline $\begin{array}{l}\text { Izdavač: } \\
\text { IZ }\end{array}$ & autorski reprint \\
\hline $\begin{array}{l}\text { Mesto i adresa: } \\
\text { MA }\end{array}$ & 21000 Novi Sad, Srbija, Hajduk Veljkova 3 \\
\hline & \\
\hline
\end{tabular}




\begin{tabular}{|c|c|}
\hline $\begin{array}{l}\text { Fizički opis rada: } \\
\text { FO }\end{array}$ & $\begin{array}{l}8 \text { poglavlja, } 137 \text { stranica, } 43 \text { tabele, } 3 \text { slike, } 9 \\
\text { grafikona, } 269 \text { referenci }\end{array}$ \\
\hline $\begin{array}{l}\text { Naučna oblast: } \\
\text { NO }\end{array}$ & Medicina \\
\hline $\begin{array}{l}\text { Naučna disciplina: } \\
\text { ND }\end{array}$ & Stomatologija (Parodontologija) \\
\hline $\begin{array}{l}\text { Predmetna odrednica, ključne reči: } \\
\text { PO }\end{array}$ & $\begin{array}{l}\text { Parodontalne bolesti; Parodontalni indeks; } \\
\text { Oksidativni stres; Pljuvačka; Deoksiguanozin; } \\
\text { Superoksid dismutaza; Malondialdehid }\end{array}$ \\
\hline UDK & 616.311-008.9-074 \\
\hline $\begin{array}{l}\text { Čuva se: } \\
\text { ČU }\end{array}$ & $\begin{array}{l}\text { U biblioteci Medicinskog fakulteta Univerziteta } \\
\text { u Novom Sadu }\end{array}$ \\
\hline $\begin{array}{l}\text { Važna napomena: } \\
\text { VN }\end{array}$ & \\
\hline $\begin{array}{l}\text { Izvod: } \\
\text { IZ }\end{array}$ & $\begin{array}{l}\text { Uvod: Oksidativni stres nastao usled nesklada u } \\
\text { produkciji slobodnih radikala i antioksidativnoj } \\
\text { zaštiti sve češće se prepoznaje kao biohemijski } \\
\text { mehanizam potencijalno uključen u } \\
\text { patogenetska zbivanja u velikom broju } \\
\text { sistemskih bolesti, pa tako i parodontopatije. Sa } \\
\text { druge strane, parodontopatija kao inflamatorno } \\
\text { destruktivno oboljenje i sama dovodi do } \\
\text { pojačanog stvaranja slobodnih radikala. } \\
\text { Ispitivanja pokazuju da parodontopatiju ne prati } \\
\text { samo poremećaj u redoks ravnoteži lokalno u } \\
\text { usnoj duplji, već da reaktivni oblici kiseonika } \\
\text { proizvedeni tokom parodontopatije difunduju u } \\
\text { krv dovodeći do oksidacije biomolekula krvi i } \\
\text { nastanka cirkulatornog oksidativnog stresa. } \\
\text { Cilj: Cilj ovog istraživanja bio je da uporedimo } \\
\text { stepen oksidativnog stresa u pljuvački i krvi u } \\
\text { grupi pacijenata sa parodontopatijom i grupi } \\
\text { pacijenata sa zdravim parodoncijumom kao i da } \\
\text { ispitamo uticaj kauzalne terapije } \\
\text { parodontopatije na stepen oksidativnog stresa u } \\
\text { pljuvački i krvi kod pacijenata sa } \\
\text { parodontopatijom. } \\
\text { Materijal i metode: U istraživanje je bilo } \\
\text { uključeno 30 pacijenata sa hroničnom } \\
\text { parodontopatijom i 20 ispitanika sa zdravim } \\
\text { parodoncijumom.Za procenu } \\
\text { parodoncijuma korišćeni su: Plak indeks (PI), } \\
\text { Gingivalni indeks (GI), Indeks krvarenja } \\
\text { gingive (IK), Dubina sondiranja (DS) i Nivo } \\
\text { pripojnog epitela (NPE). }\end{array}$ \\
\hline
\end{tabular}




\begin{tabular}{|c|c|}
\hline & \begin{tabular}{|l} 
Laboratorijsko ispitivanje se sastojalo od \\
određivanja markera oksidativnog oštećenja \\
DNK-8-hidroksideoksiguanozina (8-OHdG), \\
markera peroksidacije lipida-malondialdehida \\
(MDA) i antioksidativnog enzima-superoksid- \\
dismutaze (SOD) u pljuvački i krvi. Kod \\
pacijenata sa parodontopatijom bila je preduzeta \\
kauzalna terapija. Klinička procena stanja \\
parodoncijuma i laboratorijska ispitivanja su \\
vršena na početku istraživanja i 3 meseca nakon \\
završetka kauzalne terapije kod pacijenata sa \\
parodontopatijom, odnosno samo na početku \\
istraživanja kod pacijenata sa zdravim \\
parodoncijumom. \\
Rezultati: Vrednosti svih ispitivanih markera \\
oksidativnog stresa u pljuvački pacijanata sa \\
parodontopatijom bile su statistički značajno \\
više u odnosu na pacijente sa zdravim \\
parodoncijumom (8-OHdG p=0,043, MDA \\
p=0,000 i SOD p=0,002). Pacijenti sa \\
parodontopatijom imali su i statistički značajno \\
višu vrednost MDA u krvi u odnosu na zdrave \\
pacijente (p=0,013), dok se vrednosti 8-OHdG \\
SOD nisu razlikovale među ispitivanim \\
grupama. Nakon sprovedene kauzalne terapije \\
parodontopatije došlo je do značajnog \\
smanjenja svih ispitivanih markera oksidativnog \\
stresa u pljuvački, dok su njihove vrednosti u \\
krvi ostale gotovo nepromenjene. \\
Zaključak: Pacijenti sa parodontopatijom imali \\
su značajno više vrednosti markera \\
oksidativnog stresa u pljuvački i značajno višu \\
vrednost MDA u krvi u odnosu na pacijente sa \\
zdravim parodoncijumom. Kauzalna terapija \\
parodontopatije dovela je do značajnog \\
smanjenja markera oksidativnog stresa u \\
pljuvački, dok na vrednost ovih markera u krvi \\
nije imala uticaj.
\end{tabular} \\
\hline $\begin{array}{l}\text { Datum prihvatanja teme od strane } \\
\text { NN veća: } \\
\text { DP }\end{array}$ & 21.06 .2011$. \\
\hline $\begin{array}{l}\text { Datum odbrane: } \\
\text { DO }\end{array}$ & \\
\hline
\end{tabular}




\begin{tabular}{|l|l|}
\hline $\begin{array}{l}\text { Članovi komisije: } \\
\text { (ime i prezime / titula / zvanje / } \\
\text { naziv organizacije / status) }\end{array}$ & $\begin{array}{l}\text { predsednik: Prof. dr Saša Čakić, redovni } \\
\text { kO }\end{array}$ \\
& Beogradu \\
član: Prof. dr Snežana Brkić, redovni profesor, & Medicinski fakultet Univerzitet u Novom Sadu \\
& $\begin{array}{l}\text { član: Prof. dr Dubravka Marković, redovni } \\
\text { profesor, Medicinski fakultet Univerzitet u } \\
\text { Novom Sadu } \\
\text { član: Prof. dr Zoran Aleksić, vanredni profesor, } \\
\text { Stomatološki fakultet Univerzitet u Beogradu } \\
\text { član: Prof. dr Saša Janković, vanredni profesor, } \\
\text { Stomatološki fakultet Univerzitet u Beogradu }\end{array}$ \\
\hline
\end{tabular}




\section{UNIVERSITY OF NOVI SAD \\ MEDICAL FACULTY NOVI SAD \\ KEY WORD DOCUMENTACION}

\begin{tabular}{|l|l|}
\hline $\begin{array}{l}\text { Accession number: } \\
\text { ANO }\end{array}$ & \\
\hline $\begin{array}{l}\text { Identification number: } \\
\text { INO }\end{array}$ & \\
\hline $\begin{array}{l}\text { Document type: } \\
\text { DT }\end{array}$ & Monograph documentation \\
\hline $\begin{array}{l}\text { Type of record: } \\
\text { TR }\end{array}$ & Textual printed material \\
\hline $\begin{array}{l}\text { Contents code: } \\
\text { CC }\end{array}$ & PhD thesis \\
\hline $\begin{array}{l}\text { Author: } \\
\text { AU }\end{array}$ & Tanja Predin \\
\hline $\begin{array}{l}\text { Mentor: } \\
\text { MN }\end{array}$ & Prof. dr Milanko Đurić \\
\hline $\begin{array}{l}\text { Title: } \\
\text { TI }\end{array}$ & Oxidative stress in patients with periodontitis \\
\hline $\begin{array}{l}\text { Language of text: } \\
\text { LT }\end{array}$ & Serbian (latin) \\
\hline $\begin{array}{l}\text { Language of abstract: } \\
\text { LA }\end{array}$ & eng. / srp. \\
\hline $\begin{array}{l}\text { Country of publication: } \\
\text { CP }\end{array}$ & Republic of Serbia \\
\hline $\begin{array}{l}\text { Locality of publication: } \\
\text { LP }\end{array}$ & Vojvodina \\
\hline $\begin{array}{l}\text { Publication year: } \\
\text { PY }\end{array}$ & 2014. \\
\hline $\begin{array}{l}\text { Publisher: } \\
\text { PU }\end{array}$ & Author's reprint \\
\hline $\begin{array}{l}\text { Publication place: } \\
\text { PP }\end{array}$ & 21000 Novi Sad, Serbia, Hajduk Veljkova 3 \\
\hline
\end{tabular}




\begin{tabular}{|c|c|}
\hline $\begin{array}{l}\text { Physical description: } \\
\text { PD }\end{array}$ & $\begin{array}{l}8 \text { chapters, } 137 \text { pages, } 43 \text { tables, } 3 \text { pictures, } \\
9 \text { graphics, } 269 \text { references }\end{array}$ \\
\hline $\begin{array}{l}\text { Scientific field } \\
\text { SF }\end{array}$ & Medicine \\
\hline $\begin{array}{l}\text { Scientific discipline } \\
\text { SD }\end{array}$ & Dentistry (Periodontology) \\
\hline $\begin{array}{l}\text { Subject, Key words } \\
\text { SKW }\end{array}$ & $\begin{array}{l}\text { Periodontal Diseases; Periodontal Index; } \\
\text { Oxidative Stress; Saliva; Deoxyguanosine; } \\
\text { Superoxide Dismutase; Malondialdehyde }\end{array}$ \\
\hline UC & 616.311-008.9-074 \\
\hline $\begin{array}{l}\text { Holding data: } \\
\text { HD }\end{array}$ & $\begin{array}{l}\text { Library of Medical faculty University of Novi } \\
\text { Sad }\end{array}$ \\
\hline \multicolumn{2}{|l|}{$\begin{array}{l}\text { Note: } \\
\mathrm{N}\end{array}$} \\
\hline & $\begin{array}{l}\text { Introduction: Oxidative stress arises due to the } \\
\text { imbalance between the free radical production } \\
\text { and the antioxidant defenses and is increasingly } \\
\text { being recognized as a biochemical mechanism } \\
\text { potentially present in pathogenic processes in a } \\
\text { significant number of systemic illnesses, } \\
\text { including periodontitis. On the other hand, } \\
\text { periodontitis, as a destructive inflammatory } \\
\text { disease, also contributes to the increased free } \\
\text { radical production. Research indicates that } \\
\text { periodontitis is accompanied not only by the } \\
\text { disruption in redox balance, localized in the oral } \\
\text { cavity, but that reactive oxygen species produced } \\
\text { during the periodontal disease are diffused into } \\
\text { the blood, leading to the oxidation of blood } \\
\text { biomolecules and the development of circulating } \\
\text { oxidative stress. } \\
\text { Aim: The aim of this study was to compare the } \\
\text { level of oxidative stress in a group of patients } \\
\text { with periodontitis to that of a group of patients } \\
\text { with healthy periodontium and to evaluate the } \\
\text { impact of non-surgical periodontal therapy on } \\
\text { the level of oxidative stress in patients with } \\
\text { periodontitis. } \\
\text { Materials and methods: Study participians were } \\
30 \text { patients with chronic periodontitis and } 20 \\
\text { periodontally healthy individuals. } \\
\text { periodontal condition was assessed: Plaque index }\end{array}$ \\
\hline
\end{tabular}




\begin{tabular}{|c|c|}
\hline $\begin{array}{l}\text { Abstract: } \\
\text { AB }\end{array}$ & $\begin{array}{l}\text { (PI), Gingival index (GI), Papilla bleeding index } \\
\text { (PBI), Probing depth (PD) and Clinical } \\
\text { attachment level (CAL). Laboratory assessment } \\
\text { consisted of determination of DNA oxidative } \\
\text { damage marker-8-hydroxydeoxyguanosine (8 } \\
\text { OHdG), marker of lipid peroxidation- } \\
\text { malondialdehyde (MDA) and antioxidant } \\
\text { enzyme-superoxid dismutase (SOD) in saliva } \\
\text { and blood. Patients with periodontitis were } \\
\text { subjected to the non-surgical periodontal } \\
\text { therapy. Clinical evaluation of periodontal } \\
\text { conditions and laboratory tests were performed } \\
\text { at baseline and } 3 \text { months after the non-surgical } \\
\text { periodontal therapy. } \\
\text { Results: The values of all studied oxidative stress } \\
\text { markers in saliva were significantly higher in } \\
\text { patients with periodontitis, compared to those } \\
\text { with healthy periodontium (8-OHdG p =0,043, } \\
\text { MDA p = 0,000 and SOD p = 0,002). The value } \\
\text { of MDA in blood was also statistically } \\
\text { significantly higher in patients with } \\
\text { periodontitis relative to healthy individuals (p = } \\
\text { 0,013), while the 8-OHdG and SOD values did } \\
\text { not differ between the studied groups. } \\
\text { Following the non-surgical periodontal therapy, } \\
\text { there was a significant reduction in the } \\
\text { oxidative stress markers in saliva, while their } \\
\text { values in the blood remained virtually } \\
\text { unchanged. } \\
\text { Conclusion: The values of oxidative stress } \\
\text { markers in saliva and MDA in blood were } \\
\text { significantly higher in patients with } \\
\text { periodontitis, compared to those with a healthy } \\
\text { periodontium. While non-surgical periodontal } \\
\text { therapy led to a significant reduction in the } \\
\text { oxidative stress markers in saliva, it had no } \\
\text { effect on the value of these markers in the } \\
\text { blood. }\end{array}$ \\
\hline $\begin{array}{l}\text { Accepted on Scientific Board on: } \\
\text { AS }\end{array}$ & 21.06 .2011 \\
\hline $\begin{array}{l}\text { Defended: } \\
\text { DE }\end{array}$ & $\begin{array}{l}\text { president: Prof. dr Saša Čakić, full professor, } \\
\text { Faculty of Dentistry University of Belgrade } \\
\text { member: Prof. dr Snežana Brkić, full professor, } \\
\text { Medical faculty University of Novi Sad }\end{array}$ \\
\hline
\end{tabular}




\begin{tabular}{|l|l|}
\hline Thesis Defend Board: & member: Prof. dr Dubravka Marković, full \\
DB & professor, Medical faculty University of Novi \\
& Sad \\
& member: Prof. dr Zoran Aleksić, associate \\
& professor, Faculty of Dentistry University of \\
& Belgrade \\
& member: Prof. dr Saša Janković, associate \\
& professor, Faculty of Dentistry University of \\
Belgrade
\end{tabular}




\section{SADRŽAJ}

I UVOD

1.1. OKSIDATIVNI STRES................................................................

1.1.1. REAKTIVNE HEMIJSKE VRSTE I OKSIDATIVNI STRES.. 1

1.1.1.1. Stvaranje slobodnih kiseoničnih radikala............................ 4

1.1.1.2. Azotni slobodni radikali...................................................... 5

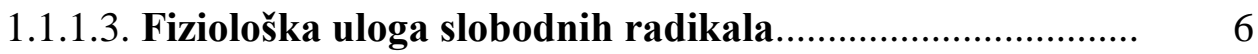

1.1.1.4. Toksični efekti slobodnih radikala........................................ 9

1.1.1.4.1. Lipidna peroksidacija................................................. 9

1.1.1.4.2. Oksidacija protein.............................. 11

1.1.1.4.3. Modifikacija DNK.............................. 12

1.1.2. ANTIOKSIDATIVNA ZAŠTITA............................................. 12

1.1.2.1. Prevencija dejstva slobodnih radikala..................... 13

1.1.2.2. Neutralizacija stvorenih slobodnih radikala................. 13

1.1.2.2.1. Enzimski mehanizmi antioksidativne zaštite...... 14

1.1.2.2.1.1. Superoksid dismutaza (SOD)............. 14

1.1.2.2.1.2. Katalaza $(C A T) \ldots \ldots \ldots \ldots \ldots \ldots \ldots \ldots \ldots . . . \ldots 16$

1.1.2.2.1.3. Glutation peroksidaza $(G S H-P x) \ldots \ldots \ldots . .17$

1.1.2.2.1.4. Glutation reduktaza $(G R)$................ 17

1.1.2.2.1.5. Glutation-S-transferaza (GST).......... 18

1.1.2.2.2. Neenzimski mehanizmi antioksidativne zaštite.... 18

1.1.2.3. Popravka i de novo sinteza oksidisanih molekula.......... 20

1.2. OKSIDATIVNI STRES I PARODONTOPATIJA........... 20

II CILJEVI ISTRAZ̆ZIVANJA ............................... 25

III RADNE HIPOTEZE ....................................... 26

IV MATERIJAL I METODE _................................................... 27

4.1. KLINIČKO ISPITIVANJE........................................................ 29

4.2. LABORATORIJSKO ISPITIVANJE...................................... 32

4.2.1. Određivanje markera oksidativnog stresa u pljuvački......... 33

4.2.2. Određivanje markera oksidativnog stresa u krvi.............. 33

4.3. STATISTIČKA OBRADA PODATAKA..................... 33 


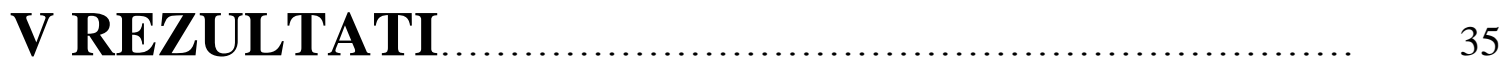

5.1. REZULTATI KLINIČKOG ISPITIVANJA................. 35

5.2. REZULTATI LABORATORIJSKOG ISPITIVANJA... 42

5.2.1. Markeri oksidativnog stresa u pljuvački............................... 43

5.2.2. Markeri oksidativnog stresa u krvi.......................... 51

5.2.3. Korelacije markera oksidativnog stresa iz pljuvačke i krvi . $\quad 59$

5.3. MARKERI OKSIDATIVNOG STRESA KOD PACIJENATA SA PARODONTOPATIJOM U ZAVISNOSTI OD

PARODONTOLOŠKOG STATUSA............................ 61

5.3.1. Markeri oksidativnog stresa u pljuvački kod pacijenata sa parodontopatijom u zavisnosti od parodontološkog statusa....... 63

5.3.2. Markeri oksidativnog stresa u krvi kod pacijenata sa parodontopatijom u zavisnosti od parodontološkog statusa....... 72

5.4. MARKERI OKSIDATIVNOG STRESA U ODNOSU NA NAVIKU PUŠENJA .............................................................................

VI DISKUSIJA ....................................................

VII ZAKLJUČCI.................................................. 109

VIII LITERATURA .......................................... 110 


\section{UVOD}

\subsection{OKSIDATIVNI STRES}

\subsubsection{REAKTIVNE HEMIJSKE VRSTE I OKSIDATIVNI STRES}

Oksidativni stres je definisao Helmut Sies 1985. godine kao poremećaj u kojem prevagu imaju slobodni radikali nad antioksidantima usled čega dolazi do oštećenja važnih ćelijskim makromolekula (proteina, lipida, ugljenih hidrata i DNK) (1) (Slika 1).

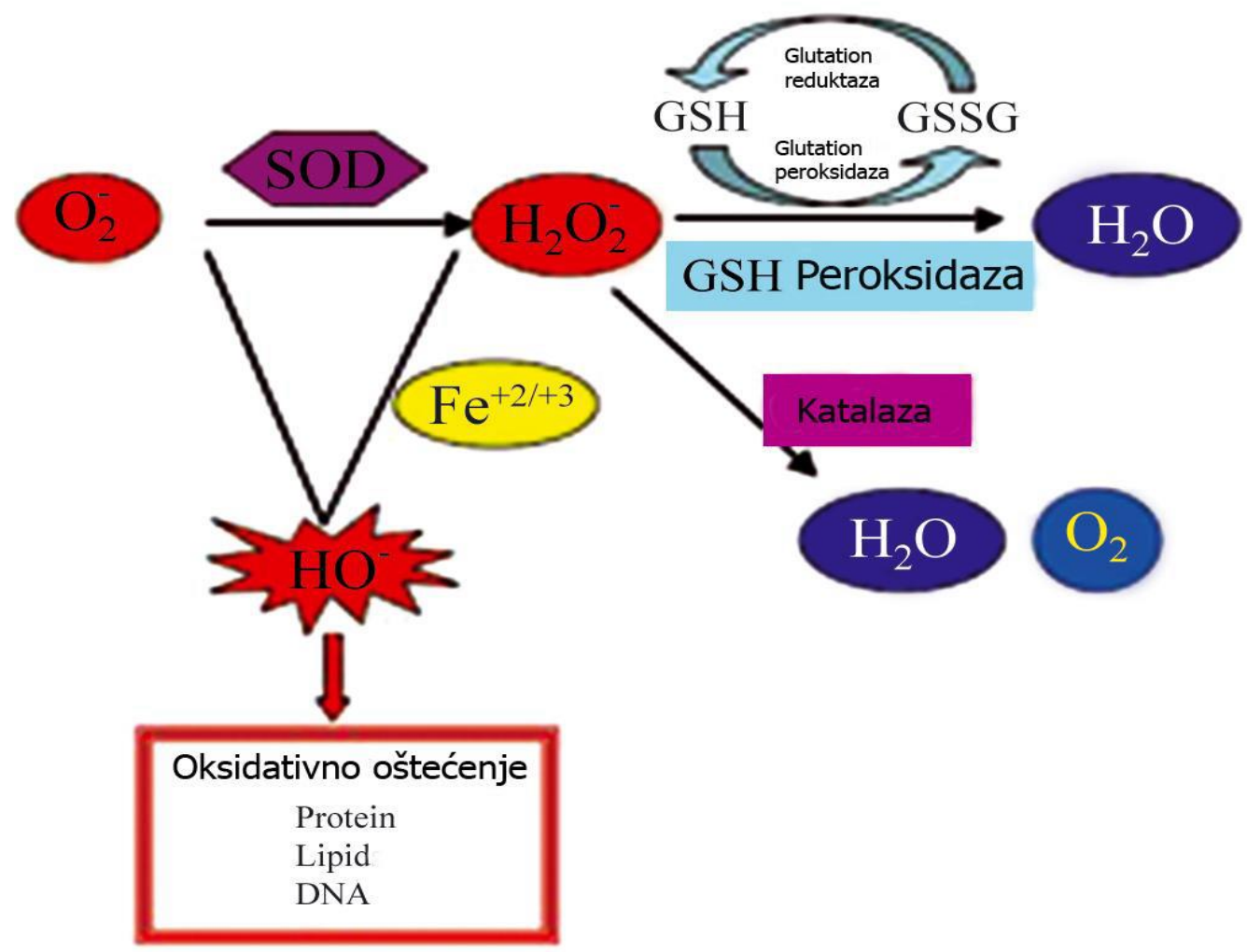

Slika 1. Poremećena ravnoteža između antioksidanata i produkcije prooksidanata dovodi do povećanog stvaranja slobodnih radikala što može dovesti do ozbiljnih ćelijskih 
oštećenja. (adaptirano iz Wakamatsu et al. Tearful relations: oxidative stress, inflammation and eye diseases. Arq. Bras. Oftalmol. 2008; 71:72-79) (2)

Proces oksidacije je deo regulatornog biohemijskog funkcionisanja ljudskog tela u procesu stvaranja energije koja je neophodna za život. Tokom normalnih metaboličkih procesa dolazi do stvaranja slobodnih radikala, koji se uključuju u uobičajene biološke procese, ali isto tako mogu biti u nekontrolisanim uslovima uzrok i oksidativnog oštećenja ćelija (3). Slobodni radikali prema tome mogu imati fiziološku ili patološku ulogu u organizmu. Oksidativno oštećenje nastaje ili zbog povećane produkcije slobodnih radikala ili zbog nedovoljne efikasnosti antioksidativnog sistema zaštite.

Slobodni radikali su atomi, atomske grupe ili molekuli koji sadrže jedan ili više nesparenih elektrona u poslednjoj molekulskoj, odnosno atomskoj orbitali. Nespareni elektroni su uzrok njihove visoke reaktivnosti i nestabilnosti. Težeći da spare nesparene elektrone slobodni radikali se ponašaju kao snažni elektrofili. U reakciji sa supstratom odnosno donorom elektrona, slobodni radikali se redukuju (dobijaju elektron), a supstrat se oksidiše (gubi elektron) i postaje tzv. sekundarni slobodni radikal i otpočinje lanac radikalskih reakcija. Jednom pokrenut ovaj lanac ima osobinu prostornog i vremenskog širenja uz pojačavanje efekta (4).

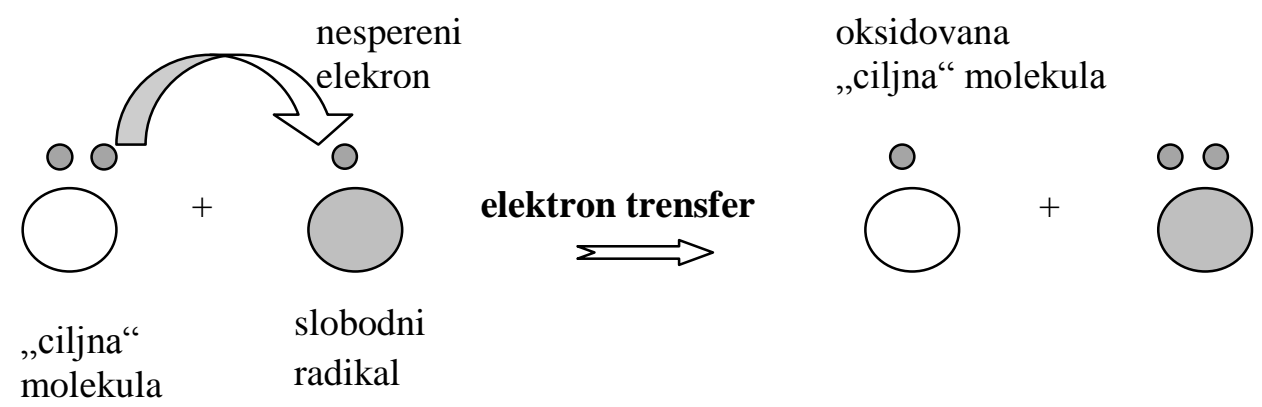

Slika 2. Mehanizam rekcije slobodnih radikala (adaptirano iz Đukić M. Oksidativni stres - Kliničko dijagnostički značaj. Beograd: Mono i Manjana; 2008.) 
Slobodni radikali se u organizmu konstantno stvaraju i pri niskim koncentracijama ostvaruju svoju fiziološku ulogu u regulaciji signalnih puteva unutar ćelije i među ćelijama, fagocitozi, aktivaciji leukocita, u sintezi esencijalnih bioloških jedinjenja i proizvodnji energije, ćelijskom rastu i programiranoj ćelijskoj smrti-apoptozi (5). Međutim, u situaciji povećanog stvaranja i/ili neadekvatnog uklanjanja slobodnih radikala dolazi do narušavanja redoks homeostaza ćelije i ispoljavanja negativnog efekta, odnosno nastanka oksidativnog stresa. Ovako stvoreni "višak" slobodnih radikala, dovodi do oštećenje ćelijskih lipida, proteina i nukleinskih kiselina. Osim toga, slobodni radikali mogu da menjaju signalnu transdukciju i ekspresiju gena, te na taj način doprinose patološkim procesima u organizmu (6). Utvrđeno je da su slobodni radikali uključeni u patogenezu dijabetes melitusa, ateroskleroze, HIV infekcije, autoimunih, neurodegenerativnih, malignih, inflamatornih i mnogih drugih oboljenja. Oksidativni stres učestvuje i u procesu starenja. Ćelijsko starenje je praćeno specifičnim funkcionalnim i morfološkim promenama, prouzrokovanim opadanjem i postepenim gašenjem mnogobrojnih ćelijskih procesa. U procesu starenja slabi prirodna antioksidativna sposobnost usled genetički programirane redukcije u sintezi antioksidanasa, što potencira dejstvo slobodnih radikala (7).

Termin reaktivne vrste se u literaturi sve više koristi umesto termina slobodni radikali imajući u vidu da su ovim pojmom obuhvaćene sve klase jedinjenja elektrofilnog karaktera visoke reaktivnosti. U zavisnosti od aktivnog centra oni se dele na reaktivne vrste sa kiseonikom (ROS), azotom (RNS), ugljenikom (RCS) i sumporom (RSS). Najznačajnije reaktivne vrste u živim sistemima su reaktivne kiseonične vrste (ROS) u koje se ubrajaju: superoksidni anjon $\left(\mathrm{O}_{2}{ }^{-}\right)$, hidroksil radikal ( $\left.\mathrm{HO}\right)$, peroksil radikal (ROO), alkoksil radikal (RO), hidroperoksil radikal (HOO), kao i neradikalske vrste: vodonik peroksid, hipohlorna kiselina, ozon, singlet kiseonik. U RNS se ubrajaju slobodno radikalske vrste kao što su nitroksil radikal (NO) i azot dioksid radikal $\left(\mathrm{NO}_{2}\right)$ kao i neradikalske vrste: azodioksid anjon, azot trioksid, nitronijum jon, peroksinirit anjon, alkil peroksinitrit, nitroksil anjon, nitrozil katjon i nitril hlorid. U RCS spadaju alkil radikal $(\mathrm{R})$, alkoksil radikal (RO), peroksil radikal (ROO), dok se u RSS ubrajaju tiil radikal (RS ), glutatiil radikal (GS ) i diglutatiil anjon radikal (GSSG ${ }^{\circ}$ ) (8). 
U proučavanju živih organizama najveći značaj imaju slobodni kiseonični radikali (ROS) i reaktivna azotova jedinjenja (RNS).

\subsubsection{Stvaranje slobodnih kiseoničnih radikala}

Najznačajniji izvor stvaranja ROS svakako predstavlja proces ćelijskog disanja tj. oksidativne fosforilacije u mitohondrijama. Od ukupno unetog molekularnog kiseonika $\left(\mathrm{O}_{2}\right), 90 \%$ dospeva u mitohondrije, gde se tokom ćelijskog disanja, odvija četvoroelektronska redukcija $\mathrm{O}_{2}$ do $\mathrm{H}_{2} \mathrm{O}$, a oslobođena energija se koristi za sintezu adenozin trifosfata (ATP). Usled slabih veza između elektrona i odgovarajućih enzima koji učastvuju u njihovom prenosu, dolazi do "curenja" elektrona i stvaranja ROS (9). Tokom ćelijskog disanja $2 \%$ kiseonika ne podleže potpunoj redukciji do $\mathrm{H}_{2} \mathrm{O}$ tj. učestvuje u stvaranju ROS. Zbog toga se mitohondrijalni respiratorni lanac smatra najznačajnijim izvorom $\mathrm{O}_{2}$ - Superoksid se stvara i dejstvom NADPH kao prvi korak u reakciji fagocita tokom inflamacije, ali i u procesu apoptoze.

$$
\mathrm{NADPH}+2 \mathrm{O}_{2} \longrightarrow \mathrm{NADP}^{+}+\mathrm{H}^{+}+\mathrm{O}_{2}{ }^{-}
$$

Superoksid anjon radikal nastaje i pri autooksidaciji flavina, pterina, kateholamina, kao i delovanjem spoljašnjih agenasa kao što je zračenje i delovanjem citostatika. Može nastati i oksidacijom hemoglobina i mioglobina u methemoglobin i metmioglobin (10). U fiziološkim uslovima $\mathrm{O}_{2}{ }^{--}$ne izaziva toksične efekte jer ga enzim superoksid dismutaza (SOD) transformiše u manje aktivan vodonik peroksid.

$$
\mathrm{O}_{2}{ }^{\cdot}+2 \mathrm{H}^{+} \stackrel{\mathrm{SOD}}{\longrightarrow} \mathrm{O}_{2}+\mathrm{H}_{2} \mathrm{O}_{2}
$$

Izoenzimi SOD nalaze se u mitohondrijama (mitohondrijska SOD-MnSOD), citosolu (citosolna SOD-CuZnSOD) i na površini ćelija. Slobodni kiseonični radikali imaju važnu ulogu u održavanju redoks potencijala ćelije. Prisustvo veće koncentracije $\mathrm{O}_{2}-$ stimuliše stvaranje hidroksil radikala reakcijom sa vodonik-peroksidom ili oksidacijom gvožđa. 
Glavno mesto svaranja vodonik peroksida $\left(\mathrm{H}_{2} \mathrm{O}_{2}\right)$ u ćelijama su peroksizomi. Vodonik peroksid poseduje brojne toksične efekte uprkos činjenici da predstavlja najstabilniji intermedijerni produkt redukcije kiseonika i iako ne predstavlja pravi slobodni radikal jer nema nesparenih elektrona (11). Katalaza razlaže vodonik peroksid do vode $\mathrm{i}$ kiseonika i na taj način smanjuje njegovu toksičnost. $\mathrm{H}_{2} \mathrm{O}_{2}$ dovodi do oksidacije sulfhidrilnih grupa proteina i do inicijacije procesa lipidne peroksidacije, a u reakciji sa jonima metala dovodi do stvaranja izuzetno reaktivnog hidroksil radikala (3). Hidroksil radikal (HO ) kao neutralni oblik hidroksil anjona predstavlja najreaktivniji intermedijerni produkt parcijalne redukcije kiseonika i ima veoma kratak poluživot, svega $10^{-9} \mathrm{~s}(12)$. U situacijama kada dođe do oštećenja peroksizoma, veliki deo $\mathrm{H}_{2} \mathrm{O}_{2}$ se oslobađa $u$ citoplazmu, indukujući stanje oksidativnog stresa u ćeliji.

Peroksil radikali (ROO), su derivati $\mathrm{O}_{2}$ koji takođe nastaju u živim sistemima. Najjednostavniji peroksil radikal je protonovana forma $\mathrm{O}_{2}{ }^{\circ-}$ koji se naziva hidroperoksil radikal ili perhidroksil radikal (HOO). Hidroperoksil radikal vrši peroksidaciju polinezasićenih masnih kiselina u procesu koji se zove lipidna peroksidacija (LP).

ROS mogu nastati i kao posledica dejstva raznih spoljašnjih uticaja, kao što su elektromagnetno zračenje i radijacija, zagadjenje vazduha, duvanski dim, ali i kao posledica metabolizma raznih lekova, pesticida i rastvarača (13).

\subsubsection{Azotni slobodni radikali}

Tokom normalnog metabolizma ćelije osim reaktivnih kiseoničnih vrsta (ROS) stvaraju se i azotni radikali (RNS). Azot monoksid (NO) nastaje oksidacijom L-arginina u prisustvu enzima azot monoksid sintetaza (NOS) (14). U fiziološkim uslovima azot monoksid kontroliše razne ćelijske procese: tonus krvnih sudova, smanjuje adheziju i agregaciju trombocita, reguliše tonus glatkih i poprečno-prugastih mišića, učestvuje u neuroendokrinoj regulaciji; reguliše glad, bol i san (15-17). NO je neurotransmiter, a u imunom sistemu modulira citotoksičnost makrofaga. Pod određenim okolnostima NO učestvuje u izvesnim patofiziološkim procesima (18). Azot monoksid postoji u nekoliko hemijskih formi (NO-, NO, NO+) i zato ima širok dijapazon dejstva i bioloških funkcija. 
$\mathrm{NO}^{+}$i $\mathrm{NO}^{-}$pokazuju zaštitna svojstva, za razliku od NO. U endotelnim ćelijama i makrofagima $\mathrm{NO}$ reaguje $\mathrm{sa}_{2} \mathrm{O}_{2}{ }^{\circ} \mathrm{i}$ gradi visoko reaktivno jedinjenje peroksinitrit $\left(\mathrm{ONOO}^{-}\right)$. Protonovanjem peroksinitrita nastaje peroksinitritna kiselina $(\mathrm{ONOOH})$ koja je vrlo nestabilna i njeni degradacioni produkti, $\mathrm{OH}$ i $\mathrm{NO}_{2}$ - azot dioksid radikal, vrlo aktivni radikali, doprinose sveukupnom citotoksičnom efektu (19).

\subsubsection{FIZIOLOŠKA ULOGA SLOBODNIH RADIKALA}

Osnovne fiziološke funkcije slobodnih radikala su fagocitoza, signalna transdukcija i apoptoza.

Slobodni kiseonični radikali predstavljaju prvu liniju odbrane od infektivnih agenasa. Tokom procesa fagocitoze $\mathrm{u}$ aktiviranim polimorfonuklearnim leukocitima $\mathrm{i}$ makrofagima dešava se "oksidaciona eksplozija" usled i do 20 puta povećane potrošnje $\mathrm{O}_{2}$ i prekomerne produkcije $\mathrm{O}_{2}{ }^{\circ}$, povećanog stvaranja $\mathrm{H}_{2} \mathrm{O}_{2}$ i drugih $\mathrm{ROS}$ s ciljem uništavanja mikroorganizama (8). Odmah po unosu stranog tela u fagocit počinje oksidativna eksplozija. Pod dejstvom NADPH oksidaze, citokini - interleukin 1 i TNF (tumor necrosis factor) podstiču ovaj proces. Naime, NADPH oksidaza kao donor elektrona katalizuje jednoelektronsku redukciju kiseonika u superoksid anjon radikal. Tokom procesa oksidativne eksplozije oko $90 \%$ kiseonika u fagocitima transformiše se u superoksid anjon radikal. U reakciji dva molekula superoksid anjon radikala jedan se redukuje, a drugi se oksidiše pri čemu nastaju vodonik peroksid i kiseonik. Sintezu vodonik peroksida u fagocitima omogućava i direktna dvovaletna redukcija molekulskog kiseonika. Interakcijom superoksid anjon radikala i vodonik peroksida nastaje hidroksilni radikal, a interakcijom superoksida i azot-monoksida nastaje peroksinitritni radikal (20).

Superoksid radikal u fagocitima uništava fagocitovane čestice putem inaktivacije membranskih lipida, intracelularnih proteina (enzima i receptora), deoksiribonukleinske (DNK) i ribonukleinske kiseline (RNK). Tako nastaje liza fagocitovane bakterijske ćelije za 30 do 60 minuta. Međutim, da bi došlo do potpunog uništavanje bakterija neophodno je prisustvo proteaza (21). Potrošnja kiseonika u neaktivnim fagocitima zavisi od vrste ćelija. 
Neutrofili troše malo kiseonika čak i u sredini bogatoj kiseonikom dok alveolarni makrofagi uglavnom obezbeđuju energiju na račun potrošnje kiseonika. Međutim na podsticaj stimulusa i jedni i drugi povećavaju potrošnju kiseonika (22).

Signalna transdukcija predstavlja proces transmisije signala sa ćelijske površine u unutrašnjost ćelije (23). U složenom sistemu prenosa informacija kroz ćeliju do ciljnih molekula, koji inicijacijom ekspresije gena i posledičnom sintezom odgovarajućih funkcionalnih ili strukturnih proteina omogućavaju ćeliji adaptaciju i preživljavanje, slobodni radikali zauzimaju značajno mesto kao pokretači, prenosioci i/ili modifikatori ćelijskog odgovora (4).

Slobodni radikali i njihovi metaboliti uključeni su u složen sistem različitih signalnih puteva, najverovatnije tako što kao intracelularni i intercelularni posrednici transformišu inicijalni signal $\mathrm{u}$ biohemijski odgovor ćelije. Oksidanti u svojstvu sekundarnih glasnika ostvaruju svoje fiziološko dejstvo koje se može manifestovati modifikacijom prenosa signala, prevođenjem sekundarnih u tercijerne glasnike ili pokretanjem ili finalizovanjem procesa signalne transdukcije $(23,24)$. Utvrđeno je da $\mathrm{H}_{2} \mathrm{O}_{2}$ može biti pravi sekundarni glasnik kada se stvara tokom fiziološkog procesa. Suprotno njemu, $\mathrm{O}_{2}$ - koji je poznat kao prekursor $\mathrm{H}_{2} \mathrm{O}_{2}$ deluje na signalne puteve posttranslacionom modifikacijom pre nego kao klasičan sekundarni glasnik (25-27). ROS su idealni unutarćelijski glasnici jer su veoma mali, visoko reaktivni i difuzibilni molekuli.

Osim uloge u fagocitozi i signalnoj transdukciji slobodni radikali imaju značajnu ulogu u procesu apoptoze. Apoptoza je poseban oblik programirane ćelijske smrti koji predstavlja nezamenjiv faktor u razvoju i homeostazi višećelijskih organizama $(28,29)$. Krajnji cilj ovog procesa je razgradnja i fagocitoza suvišnih ili oštećenih ćelija bez pokretanja zapaljenskog odgovora. Ljudski organizam apoptozom odbaci oko milion ćelija u sekundi (24). Kao primeri fiziološke apoptoze navode se uklanjanje nepotrebnih ćelija u toku organogeneze, uklanjanje neutrofila i limfocita koji su obavili svoju ulogu, uklanjanje ćelija inficiranih virusima i ćelija koje su toliko oštećene da je nemoguća njihova reparacija, kao na primer, prilikom delovanja jonizujućeg zračenja, UV zračenja ili hipoksije i tumorske alteracije. Apoptoza predstavlja i odbrambeni mehanizam kojim se organizam bori protiv maligne alteracije tih oštećenih ćelija. Tačan mehanizam apoptoze, 
tj. kaskada događaja od prepoznavanja signala na ćelijskoj površini do događaja koji se dešavaju u nukleusu, još uvek nije potpuno rasvetljen. Poznati induktori programirane ćelijske smrti su fiziološki aktivatori (TNF, tranformišući faktor rasta $\beta$, neurotransmiteri, kalcijum, nedostatak faktora rasta, gubitak matriksnih veza, glukokortikoidi), aktivatori nastali usled oštećenja (virusna infekcija, bakterijski toksini, slobodni radikali, tumorski supresori, nedostatak nutritivnih materija), terapijski agensi (hemioterapeutici, gama i UV zračenje) i toksična jedinjenja (etanol i $\beta$-amiloid peptid) (4). Pored navedenih induktora i ćelijski receptori mogu da budu uključeni u fazu aktivacije procesa apoptoze. Ovo svojstvo pre svega imaju receptori za neurotropne faktore, epidermalni faktor rast i faktor rasta trombocita, receptor faktora nekroze tumora i Fas receptor. Humani Fas je transmembranski glikoprotein koji prema strukturi pripada receptorskoj familiji TNF i nervnog faktora rasta (30). Vezivanjem odgovarajućeg ekstraćelijskog liganda (Fas ligand) za Fas receptor ubrzava se vezivanje intraćelijskih signalnih molekula kao što je Fas pridruženi domen smrti (FADD) što na kraju rezultira aktivacijom proteolitičkih enzima-kaspaza i vodi ćeliju u apoptozu (31). Dakle, programirana ćelijska smrt može biti aktivirana preko recepora, međutim, i brojni stimulusi, kao što su oksidativni stres, porast NO, dovode do disfunkcije mitohondrija i oslobađanja proapoptotičnih faktora. Stoga se može reći da postoje spoljašnji i unutrašnji signalni put koji dovode do apoptoze. Svi ligandi koji se vezuju za membranske receptore, kao što je Fas, aktivišu spoljašnji put, dok faktori koji dovode do disfunkcije mitohondrija ili do stresa endoplazmatskog retikuluma indukuju unutrašnji put (4).

Azot monoksid je jedan od najčešće spominjanih slobodnih radikala kada je reč o apoptozi. Ovaj molekul može i da izazove i da spreči apoptozu u zavisnosti od tipa ćelije, nivoa stresa, redoks stanja i hemijske forme samog NO, kao i od sposobnosti ćelije da neutrališe stvorene slobodne radikale. Kada NO deluje preko sistema cikličnog guoanozinmonofosfata (cGMP) onda sprečava ćelijsku smrt. Takođe, NO može da deaktivira kapsaze, potentne apoptotične proteine, ali i druge proteine sličnih funkcija $(28,32,33)$. 


\subsubsection{TOKSIČNI EFEKTI SLOBODNIH RADIKALA}

\subsection{Lipidna peroksidacija}

Lipidna peroksidacija je proces oksidativnog oštećena lipida. Ćelijska membrana kao i membrane subćelijskih organela predstavljaju mesto gde otpočinje oksidativno oštećenje lipida, tj. lipidna peroksidacija (LPO) usled velike zastupljenosti lipida u njima. Kao posledica oštećenja lipida ćelijske membrane dolazi do smanjenje fluidnosti, povećane propustljivosti za jedno i dvovalentne jone, inaktivacije membranskih enzima i gubitka integriteta membrane. Ruptura lizozomskih membrana oslobađa hidrolitičke enzime, što sveukupno dovodi do vitalnih ćelijskih poremećaja i na kraju do smrti ćelije (4). Ozbiljnost ćelijskog oštećenja zavisiće od toga na kojim subćelijskim membranama (organele, jedro) se odvija lipidna peroksidacija. Ovaj proces može biti započet enzimskim putem ili neenzimskim putem. Enzimski put podrazumeva delovanje lipooksigenaze, ciklooksigenaze i citohrom P450 katalizovane reakcije, dok neenzimski put predstavlja delovanje slobodnih radikala na nezasićene lipide membrana (autooksidacija i fotooksidacija).

Produkti lipidne peroksidacije imaju dug poluživot, veoma su reaktivni, zbog čega mogu da utiču na brojne druge biomolekule, proteine i nukleinske kiseline. Zbog toga su oni proaterogeni, proinflamatorni, potencijalno toksični, mutageni i karcinogeni (34-39). Međutim, produkti lipidne peroksidacije imaju i neke biološke funkcije. Naime, oni učestvuju u intracelularnom prenošenju signala, regulaciji genske ekspresije, aktivaciji transkriptora i faktora rasta (40-43).

Peroksidacija polinezasićenih masnih kiselina (PNMK) protiče kroz tri stadijuma: inicijaciju, propagaciju i terminaciju. Proces inicijacije podrazumeva pokretanje lančanih reakcija, kada se generišu lipidni radikali ( $\mathrm{R}^{*}$ - alkil radikal). Propagaciona faza se nadovezuje na prethodnu i podrazumeva reakciju lipidnog radikala $\left(\mathrm{R}^{\circ}\right)$ sa molekularnim kiseonikom $\left(\mathrm{O}_{2}\right)$, pri čemu nastaje peroksil radikal ( $\left.\mathrm{ROO}^{\circ}\right)$. Peroksil radikal je nosilac dalje propagacije lipidne peroksidacije, koji brzo i lako reaguje sa sledećom masnom 
kiselinom. Lipidna peroksidacije se završava pretvaranjem vodonik peroksida u sekundarne neradikalne molekule - ugljen vodonike, aldehide, alkohole i ketone ili stvaranjem polimera. Prisustvo antioksidanta olakšava okončanje lančane reakcije, a konačni efekti lipidne peroskidacije zavisiće od krajnjih produkata. Malondialdehid (MDA), terminalni produkt oksidativnog oštećenja PNMK, unakrsno se vezuje za proteine i fosfolipide membrane, čime se produbljuje oksidativno oštećenje biomolekula i priznat je kao validan marker LPO. Jedan od najznačajnijih mehanizama dejstva lipidne peroksidacije i hidroperoksida je njihov uticaj na homeostazu natrijuma i kalijuma. Oni aktiviraju $\mathrm{Ca}^{2+}$ - ATP-azu kao i $\mathrm{Na}^{+}-\mathrm{K}^{+}$- ATP-azu pri čemu dolazi do slobodnog prolaza $\mathrm{Ca}^{2+}$ jona $\mathrm{u}$ ćeliju što se inače ne dešava. Poremećena koncentracija $\mathrm{Ca}^{2+}$ jona unutar i van ćelije dovodi do aktivacije intracelularnih hidrolaza čime se oštećuju membranski fosfolipidi, citoskelet i membranske subcelularne organele. Na ovaj način posebno dolazi do oštećenja mitohondrija.

Merenje malondialdehida kao produkta lipidne peroksidacije najčešće se koristi kao pokazatelj inteziteta ovog procesa tj. mere oksidativnog stresa uopšte (44-46). Redosled događanja u toku lipidne peroksidacije može se prikazati na sledeći način (47):

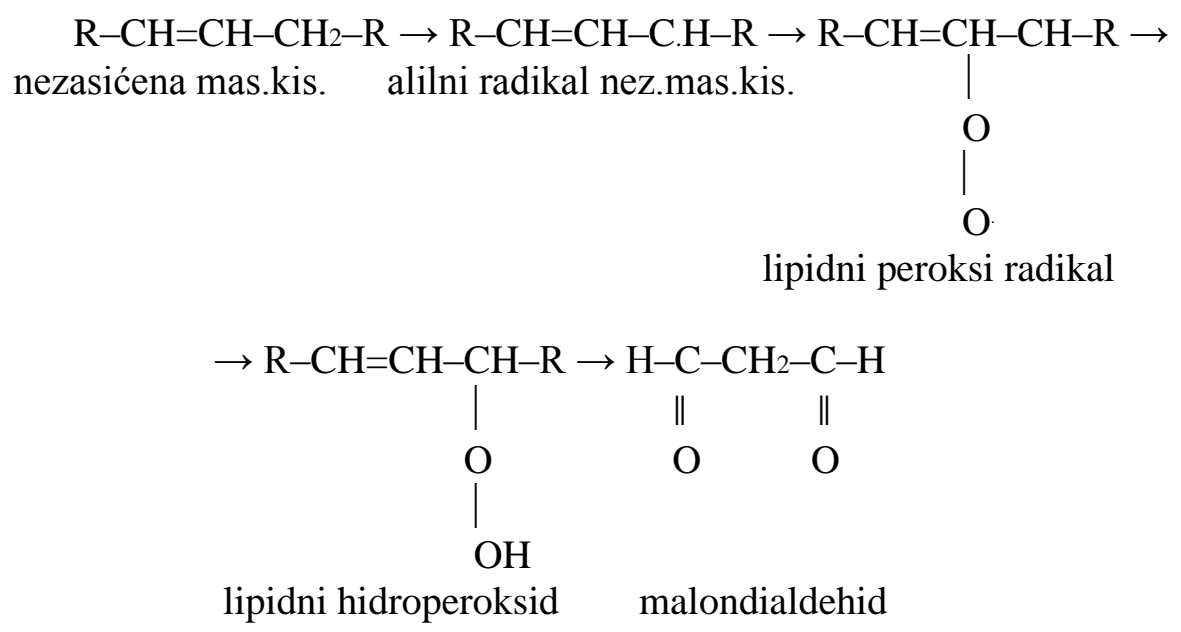


Istraživanja pokazuju da je nivo MDA povišen u tumoru pluća, dojke, želuca, grlića materice, u hroničnoj limfocitnoj leukemiji, u melanomu, u preeklampsiji, kod pacijenata sa aterosklerozom, dijabetesom, oboljenjima jetre, pacijenata sa Alchajmerovom bolešću, kao i kod pušača (48-54).

\subsection{Oksidacija proteina}

Oksidativna modifikacija proteina, odnosno aminokiselina od strane reaktivih vrsta, podrazumeva promenu primarne strukture usled reakcija na bočnim lancima aminokiselinskih ostataka, njihovog otcepljenja, konverziju proteina u proteine veće molekulske forme kao i fragmentaciju polipeptidnih lanaca (55). Oksidativana modifikacija proteina može biti indukovana reaktivnim vrstama sa kiseonikom, ugljenikom, azotom i sumporom. Stepen i vrsta oksidativnog oštećenja je determinisan afinitetom pojedinih reaktivnih vrsta prema određenim klasama biomolekula. Proteini mogu biti sa receptorskim, antigenim, transportnim ili enzimskim funkcijama (4). Aminokiseline kao osnovne jedinice proteina, predstavljaju mesta na kojima se odvijaju reakcije oksidativnog oštećenja proteina. Posebno osetljive aminokiseline na oksidaciju su metionin i cistein. Kako najveći broj mehanizama oksidacije dovodi do stvaranja karbonil derivata, ova se grupa i najčešće koristi kao marker oksidativnog oštećenja proteina (55).

Karbonil derivati mogu nastati na nekoliko načina:

1. direktnom oksidacijom aminokiselinskih ostatataka lizina, arginina, treonina i prolina

2. direktnom oskidacijom bočnog lanca glutaminske kiseline

2. sekundarnom oksidacijom lizina oksidovanim produktima šećera

3. sekundarnom oksidacijom dejstvom MDA i sličnih molekula na protein

Dakle, slobodni radikali mogu delovati direktno na protein ili oksidacija proteina može biti posledica oksidacije druge vrste molekula (lipida ili ugljenih hidrata) (56-58). Tako na primer, procesi lipidne peroksidacije pored lipida deluju i na proteine. Visoko reaktivni produkti lipidne peroksidacije reaguju sa slobodnim $\mathrm{SH}$ i NH2 grupama aminokiselina, peptida, proteina i nukleotida što dovodi do izmenjene funkcije ovih molekula. Naime, jedan od produkata procesa lipidne peroksidacije-malondialdehid (MDA) može reagovati sa slobodnim amino grupama proteina i nukleinskih kiselina i 
dovesti do novog oštećenja ćelija. Guanin u sekvenci DNK je ciljno mesto napada MDA što dovodi do mutagenih oštećenja.

\subsection{Modifikacija DNK}

Oksidativna modifikacija DNK dovodi do promene strukture DNK koje dalje dovode do genetskih oštećenja. Efekti slobodnih radikala na DNK se ispoljavaju trenutno ili odloženo. Može doći do prekida lanca, interakcija DNK azotnih baza unutar jedne spirale ili između dve spirale, oštećenja na proteinskim vezama i modifikacije baze. Oksidativna modifikacija je najizraženija u prisustvu metala sa promenljivom valencom jer tada kao produkt reakcije oksidacije nastaje najpotentniji $\mathrm{OH}^{*}$. Adicija $\mathrm{OH}^{*}$ na guanine odvija se veoma brzo i nastali 8-hidroksideoksiguanozin (8-OHdG) se smatra indikatorom oksidativnog oštećenja DNK (4). Trajno oksidativno oštećenje DNK predstavlja prvi korak u mutagenezi, karcinogenezi i starenju (3).

\subsubsection{ANTIOKSIDATIVNA ZAŠTITA}

Tokom procesa evolucije u aerobnim uslovima, kao odgovor na toksično dejstvo kiseonika, stvoren je sistem antioksidativne zaštite. Ovim sistemom organizam se štiti od štetnog dejstva i nekontrolisanog stvaranja kiseoničkih radikala u metaboličkim procesima ili ih drži u niskim koncentracijama u organizmu (59). S obzirom da se procenjuje da se dnevno po ćeliji stvori između 1 i 3 milijarde reaktivnih vrsta, značaj antioksidativne zaštite po zdravlje ljudi postaje jasan (60).

Antioksidanti se definišu kao supstance koje, u malim koncetracijama, imaju sposobnost da mehanizmom kompeticije odlože ili inhibišu oksidaciju drugih materija (61).

Osnovni načini delovanja antioksidanata su:

1. prevencija stvaranja slobodnih radikala, odnosno sprečavanje nastanka ROS. Primer je redukcija $\mathrm{H}_{2} \mathrm{O}_{2} \mathrm{u} \mathrm{H}_{2} \mathrm{O}$ pre nego što reaguje $\mathrm{sa} \cdot \mathrm{O}_{2}$ - ili jonom metala. 
2. neutralizacije slobodnih radikala (antioksidanti u užem smislu), odnosno otklanjanje nastalih slobodnih radikala pre nego što oštete biomolekule. Kao primer navodi se aktivnost $\mathrm{SOD} \mathrm{u}$ pretvaranju $\bullet \mathrm{O}_{2}-\mathrm{u} \mathrm{H}_{2} \mathrm{O}_{2}$.

3. popravke i de novo sinteze oksidisanih molekula, odnosno otklanjanje nastalih štetnih molekula i povratak izgubljenih funkcija.

\subsubsection{PREVENCIJA DEJSTVA SLOBODNIH RADIKALA}

Bitan mehanizam i prva linija odbrane od dejsta slobodnih radikala svakako jeste prevencija njihovog stvaranja ili dejstva. Primer ovog načina delovanja je hromatski omotač oko dvostrukog lanca DNA koji štiti genetski materijal od oštećenja nudeći alternativne mete za napad slobodnih radikala. Nadalje, enzimi koji mogu dovesti do stvaranja slobodnih radikala, tj. oni koji učestvuju u ćelijskom disanju i sadrže na primer jone metala kao što je citohrom oksidaza, imaju trodimenzionalnu strukturu koja sprečava izdvajanje nastalog toksičnog molekula.

U ovu grupu antioksidanata ubrajaju se i helatne materije, koje imaju sposobnost vezivanja jona metala. To su serumski metaloproteini kao što su transferin, feritin, ceruloplazmin. Njihova uloga ogleda se u prevenciji oksidacije DNA i lipida, obzirom da hidroksil radikal deluje lokalno i može da dovede do oštećenja ovih struktura (62).

Drugi značajan mehanizam odbrane od jona metala jeste povećavanje otpornosti molekula na njihovo dejstvo. Takvo dejstvo ispoljava askorbinska kiselina na lipoprotein male gustine (low density lipoprotein - LDL). U prvu liniju odbrane spada i melanin i karotenoidi koji štite od UV zračenja.

\subsubsection{NEUTRALIZACIJA STVORENIH SLOBODNIH RADIKALA}

Drugi nivo antioksidativne zaštite uključuje se u uslovima normalnog ili pojačanog stvaranja slobodnih radikala. Antioksidatni ove grupe se mogu podeliti na enzimske $\mathrm{i}$ neenzimske (63). 


\subsection{Enzimski mehanizmi antioksidativne zaštite}

Najvažniji enzimski antioksidanti su:

1. superoksid dismutaza (SOD)

2. katalaza (CAT)

3. glutation peroksidaza (GSH-Px)

4. glutation reduktaza $(\mathrm{GR})$

5. glutation-S-transferaza (GST) (36)

\subsection{Superoksid dismutaza (SOD)}

Superoksid dismutaza, prvi put je izolovana od strane Mann i Keilis 1938.godine iz krvi govečeta (hemokuprein), a njenu enzimsku aktivnost dokazali su 1969. godine Mc. Cord i Fridovich i nazvali je superoksid dismutaza $(64,65)$. Od tada interes i znanje o ovom enzimu neprestano raste.

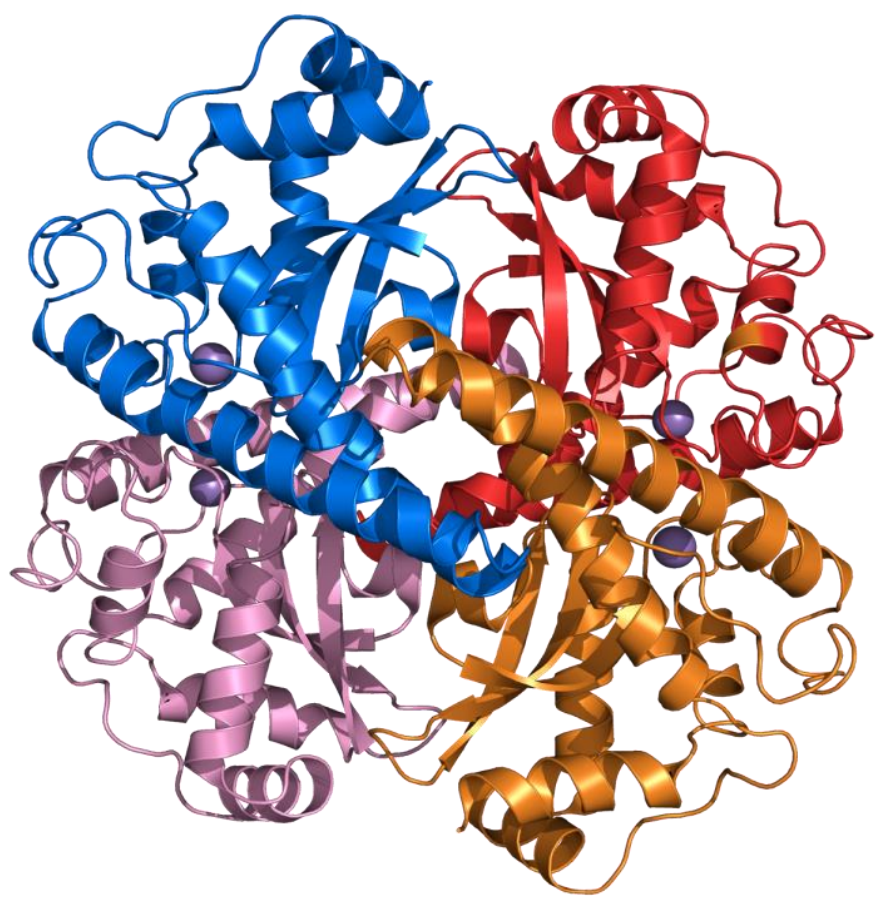

Slika3.Superoksid dismutaza

(http://upload.wikimedia.org/wikipedia/commons/1/13/Superoxide_dismutase_2_PDB_1VAR.png) 
SOD deaktivira superoksid $\left({ }^{\circ} \mathrm{O}_{2-}\right)$ u vodonik peroksid:

$$
\mathrm{O}_{2}{ }^{-}+2 \mathrm{H}^{+} \stackrel{\text { SOD }}{\longrightarrow} \mathrm{O}_{2}+\mathrm{H}_{2} \mathrm{O}_{2}
$$

Vodonik peroksid je slabo reaktivan ali u prisustvu jona gvožđa može da bude supstrat za nastanak veoma reaktivnog hidroksil jona te je važno da uz SOD u blizini bude i enzim katalaza (CAT) koji će vodonik peroksid pretvoriti u vodu i kiseonik i na taj način izvršiti njegovu potpunu deaktivaciju $(61,66)$ :

$$
2 \mathrm{H}_{2} \mathrm{O}_{2} \stackrel{\text { CAT }}{\longrightarrow} \mathrm{O}_{2}+\mathrm{H}_{2} \mathrm{O}
$$

Kod ljudi postoje tri forme SOD-a: citosolnaSOD - Cu/Zn SOD1, mitohondrijalna - MnSOD2 i ekstracelularna SOD (EC-SOD3). Sva tri izoenzima katališu istu reakciju, ali imaju svoje specifične uloge, mesto dejstva, aktivatore i deaktivatore.

Cu/Zn SOD1 ima najvažniju ulogu u odbrani od ROS i pripada mu 50-80\% ukupne aktivnosti svih oblika SOD-a. On je prisutan u svim ćelijama organizma i može se naći u najvećim koncetracijama od sve tri izoforme SOD-a (67). Inhibicija njegovog dejstva Cu-helirajućim agensom, dietilditiokarbamatom (DDC) dovodi po povećane sinteze peroksida i smanjene aktivnosti NO (68). Cink kao suplement značajno podiže nivo odbrane protiv infekcije i to indukcijom aktivnosti ovog enzima (69). Mnogi drugi faktori mogu da imaju uticaj na aktivnost ovog enzima. Njegova koncetracija raste sa godinama i veća je kod osoba ženskog pola (70). Međutim, Cu/Zn SOD1 nije vitalan enzim i istraživanja pokazuju da su životinjski modeli, sa delecijom gena za ovaj enzim, preživljavali ali uz smanjenu otpornost na oskidativni stres.

Mangan zavisna SOD ili SOD2 sadrži Mn kao kofaktor i lokalizovan je isključivo u mitohondrijama aerobnih ćelija. Mn-SOD2 ima važnu ulogu obzirom da su mitohondrije glavno mesto stvaranja superoksida tokom ćelijskog disanja. Smatra se glavnim „čistačem“ $\mathrm{O}_{2}{ }^{\circ}$. Njegova aktivnost je veoma promenljiva i značajno se povećava sa povećanjem nivoa oksidativnog stresa, što nije primećeno kod drugih izoformi SOD-a. Ovaj enzim obezbeđuje antioksidativnu zaštitu ćelije od lipidne peroksidacije kako intracelularno tako i ekstracelularno. Njegovom sekrecijom u ekstracelularni prostor 
postiže se zaštita spoljašnje ćelijske membrane. Smanjena količina Mn-SOD dovodi do povećane smrtnosti ćelija kao rezultat velike količine vodonik peroksida. Sa druge strane, povećana aktivnost ovog enzima dovodi do rezistencije malignih ćelija na antitumorsku terapiju, koja indukuje apoptozu pro-oksidativnim mehanizmima (71-74).

Ekstracelularna SOD ili SOD3 je najskorije otkrivena i sadrži $\mathrm{Cu}$ i $\mathrm{Zn} \mathrm{u}$ katalitičkom centru. Nakon sinteze, uz pomoć signalnog peptida, biva usmerena isključivo u ekstracelularni prostor. Ova izoforma SOD ima veliki afinitet za heparin i prvo je detektovana u humanoj plazmi, limfi, ascitesu i cerebrospinalnoj tečnosti. Ekspresija SOD3 je visoko ograničena na specifični tip ćelija i tkiva gde njegova aktivnost može prevazilaziti aktivnosti SOD1 i SOD2 (75). Za razliku od Zn/Cu- SOD2, EC-SOD se povećava u regijama poremećenog toka krvi, jer je kao ekstracelularan više i izložen promenama u okolnoj sredini. Njegova glavna uloga je da spreči deaktivaciju NO i kao takav ima veoma važnu ulogu u sprečavanju vazokonstrikcije i inflamacije. Međutim, njegova aktivnost opada sa godinama (76).

Superoksid dismutaza prisutna je u svim tkivima (mozak, jetra, srce, bubrezi i adrenalnim žlezdama), a aktivna je i u telesnim tečnostima (krvna plazma) (77). Smanjena aktivnost superoksid dismutaze registrovana je u nizu oboljenja, ali i povećanje aktivnog $\operatorname{SOD}(78,79)$.

\subsection{Katalaza (CAT)}

Glavna uloga katalaze kao antioksidantnog enzima je da deaktivira vodonik peroksid pretvarajući ga u vodu i kiseonik (80). Tokom jednog minuta katalaza konvertuje nekoliko miliona molekula vodonik peroksida u vodu i kiseonik. Katalaza je enzim koji sadrži hematin kao prostetičnu grupu. Upravo je hem grupa odgovorna za enzimsku aktivnost katalaze. Prisutna je u svim tkivima sisara, pri čemu se visoke koncentacije posebno nalaze u hepatocitima i eritrocitima, zatim mišićnim i nervnim ćelijama. Unutar ćelije pretežno je lokalizovana u peroksizomima i mitohondrijama. Katalaza je veoma efikasna u otklanjanju vodonik peroksida kad se on nalazi u velikim koncetracijam. U slučaju kada ga ima manje, važniju ulogu ima glutation peroksidaza. Katalaza sprečava da 
vodonik peroksid izazove oštećenja na mestima njegovog nastajanja, a to je u fagocitima $\mathrm{i}$ tokom oksidacije masnih kiselina.

\subsection{Glutation peroksidaza (GSH-Px)}

Glutation peroksidaza je enzim koji sadrži selen. Selen zamenjuje sumpor u cisteinu, čime se postiže veća efikasnost enzima kao katalizatora. GSH-Px jedini antioksidantni enzim koji u sebi ne sadrži jon metala i koristeći glutation kao supstrat jedan je od esencijalnih zaštitnika organizma od oksidativnog stresa. GSH-Px deli supstrat sa CAT. Pored vodonik peroksida GSH-Px može da deaktivira i lipidne i druge perokside, uz to je glavni zaštitnik pri niskim koncetracijama ovih slobodnih radikala. Enzim redukuje lipidne perokside do odgovarajućih hidroksi-masnih kiselina, da bi potom regenerisao svoju nativnu formu pomoću redukovanog glutationa. GSH-Px najverovatnije ima značajnu ulogu u inhibiciji inicijalnog stadijuma peroksidacije lipida ćelijskih membrana, pokrenutog difuzibilnim $\mathrm{H}_{2} \mathrm{O}_{2}$, imajući u vidu činjenicu da razlaže vodonik peroksid koji može u prisustvu metala da inicira proces lipidne peroksidacije.

U ovu familiju enzima spadaju četiri tipa peroksidaza, od kojih su najvažnija dva. Klasičan tip glutation peroksidaze (cGSH-Px) redukuje vodonik peroksid i hidroperokside masnih kiselina i holesterola, dok je fosfolipidno-hidroperoksidna glutation peroksidaza (PH-GSHPx) enzim koji redukuje lipidne perokside iz lipoproteina (81). Nalaze se u citosolu i mitohondrijama.

\subsection{Glutation reduktaza $(G R)$}

Glutation reduktaza koristi redukovanu energiju iz pentoza fosfatnog puta (NADPH) za očuvanje rezervi redukovanog glutationa u ćeliji. Ovaj enzim je efikasan čak i u uslovima visokih koncentracija vodonik peroksida. On katalizuje reakciju redukcije oksidativnog glutationa (GSSG) u redukovani glutation (GSH) uz učešće NADPH (82). Intracelularni odnos oksidovanog i redukovanog glutationa (GSSG/GSH) je odraz 
oksidativnog stanja ćelije i pokazatelj detoksikacionih kapaciteta ćelije. U ćelijama sisara nalazi se u citosolu i mitohondrijama.

\subsection{Glutation-S-transferaza (GST)}

Glutation-S-transferaza, preko sulfhidrilnih grupa, sa elektrofilnim centrima različitih supstrata, koji mogu biti ksenobiotici ili endogeni elektrofili kao i produkti oksidativnih oštećenja organizma, katališe konjugaciju redukovanog glutationa. Formiranjem konjugata nastaju hidrofilni metaboliti koji se mogu izlučiti iz organizma (83). GST predstavlja veliku grupu detoksikacionih enzima. Sve eukariotske ćelije poseduju brojne citosolne i membranski vezane izoenzime GST. Dokazano je da je nivo ekspresije GST bitan faktor koji određuje osetljivost ćelije na toksične agense. Do sada je identifikovano oko 100 hemijskih supstanci koje deluju kao induktori GST. In vivo nivo aktivnosti GST regulisan je i stvaranjem ROS, i upravo slobodni radikali nastali u redoks ciklusu su jedan od najjačih induktora ovog enzima (84).

\subsection{Neenzimski mehanizmi antioksidativne zaštite}

Glavna funkcija antioksidanata u užem smislu (neenzimski antioksidanti) je da, pre nego što dođe do oštećenja biološki aktivnog molekula, ,počiste“-odnosno neutrališu stvoren slobodni radikal. Ovo se postiže preuzimanjem ili vodonikovog jona ili prvo elektrona, a potom protona od molekula slobodnog radikala. Na brzinu i učestalost ovih reakcija utiču pre svega redoks parametri kao što su energija disocijacije i/ili potencijal jonizacije antioksidanta i sve zavisi od uticaja sredine u kojoj se reakcija odvija (85). Ako

je sredina hidrofilna, reagovaće na primer, askorbinska kiselina ili glutation, ukoliko je lipofilna onda mogu delovati $\alpha$-tokofenol (vitamin E) ili $\beta$ karoten, dok antioksidanti kao što su selen i lipoična kiselina reaguju u svim sredinama (86). 
Tabela 1. Neenzimski antioksidanti i njihova uloga (87)

\begin{tabular}{|c|c|}
\hline $\begin{array}{l}\text { NEENZIMSKI } \\
\text { ANTIOKSIDANT }\end{array}$ & ULOGA \\
\hline $\begin{array}{l}\text { Redukovani glutation } \\
\text { (GSH) }\end{array}$ & $\begin{array}{l}\text {-zaštita od vodonik peroksida } \\
\text {-zaštita od hipohlorita } \\
\text {-zaštita od hidroksil radikala } \\
\text {-zaštita od organskih radikala } \\
\text {-zaštita od peroksil radikala } \\
\text {-učestvuje u regeneraciji vitamina E }\end{array}$ \\
\hline Vitamin C & $\begin{array}{l}\text {-prekida lančane reakcije radikala } \\
\text {-sakuplja hidrofilne peroksil radikale } \\
\text {-sprečava peroksidaciju lipida } \\
\text {-regeneriše vitamin E } \\
\text {-održava integritet LDL }\end{array}$ \\
\hline Vitamin E & $\begin{array}{l}\text {-uklanja slobodne radikale } \\
\text {-prekida lančane reakcije peroksidacije } \\
\text { membranskih lipida }\end{array}$ \\
\hline Vitamin A & $\begin{array}{l}\text {-hvatač singlet kiseonika } \\
\text {-sprečava lančane reakcije radikala } \\
\text {-inhibira lipooksigenazne aktivnosti }\end{array}$ \\
\hline Koenzim Q & $\begin{array}{l}\text {-sprečava peroksidaciju lipida } \\
\text {-uklanja superoksid anjon radikal }\end{array}$ \\
\hline Albumini & $\begin{array}{l}\text {-vezuje } \mathrm{Cu}^{2+} \mathrm{i} \text { hem } \\
\text {-uklanja hipohlorastu kiselinu }\end{array}$ \\
\hline Ceruloplazmin & $\begin{array}{l}\text {-vezuje hem, } \mathrm{Cu}^{2+}, \mathrm{Fe}^{2+} \\
\text {-uklanja hipohlorastu kiselinu } \\
\text {-reaguje sa superoksid radikalom i vodonik } \\
\text { peroksidom }\end{array}$ \\
\hline Transferin i laktoferin & -direktno vezuju slobodno gvožđe \\
\hline Haptoglobin & -vezuje slobodni hemoglobin \\
\hline Hemopeksin & -vezuje slobodni hem \\
\hline Mokraćna kiselina & -uklanja slobodne radikale \\
\hline Beta-karoten & -inhibira peroksidaciju lipida \\
\hline Bilirubin & -inhibira peroksidaciju lipida \\
\hline
\end{tabular}




\subsubsection{POPRAVKA I DE NOVO SINTEZA OKSIDISANIH MOLEKULA}

Treći nivo antioksidativne zaštite ostvaruju enzimski antioksidanti koji učestvuju u reparaciji nastalog oksidativnog oštećenja lipida, proteina, ugljenih hidrata i nukleinskih kiselina. Enzimi odgovorni za reparaciju i delimično ili potpuno remodelovanje oksidisanih supstrata su: klasična i fosfolipid-zavisna glutation peroksidaza, fosfolipaza $A_{2}$, različiti proteolitički enzimi, endo- i egzonukleaze, DNK-ligaze i DNK-polimeraze, specifične oksidoreduktaze (tiol-transferaza, protein- ADP-ribozil-transferaza i ATP i

$\mathrm{Ca}^{2+-}$ nezavisna transferaza) (8). Protektivne komponente antioksidativnog sistema su u značajno većim koncentracijama prisutne unutar ćelije nego u ekstracelularnom prostoru. Enzimi antioksidativnog sistema imaju ulogu u biotransformaciji primarnih i sekundarnih slobodnih radikala $\left(\mathrm{O}_{2}^{-}, \mathrm{H}_{2} \mathrm{O}_{2}, \mathrm{R}^{\circ}, \mathrm{RO}^{\circ}, \mathrm{ROO}\right)$ u manje aktivna jedinjenja $\mathrm{i} u$ obezbeđivanju dovoljne količine redukcionih ekvivalenata $\mathrm{u}$ ćeliji, neophodnih za prevenciju razvoja oksidativnog stresa.

\subsection{OKSIDATIVNI STRES I PARODONTOPATIJE}

Oksidativni stres se danas prepoznaje kao važan faktor u nastanku ozbiljnih patoloških promena i sistemskih oboljenja kao što su ateroskleroza, dijabetes, reumatoidni artritis, neurodegenerativne bolesti, moždani i srčani infarkt, karcinom, a smatra se da se nalazi i u samoj osnovi procesa starenja $(88,89)$. Novija istraživanja govore u prilog hipotezi da oksidativni stres može biti uključen i u etiopatogenezu parodontopatija (90).

Parodontopatije predstavljaju jedno od najčešćih oboljenja čoveka i glavni uzrok gubitka zuba posle četrdesetpete godine života (91) a karakterišu se inflamacijom i destrukcijom potpornog aparata zuba. Ključnu ulogu u njihovom nastanku igraju mikroorganizmi dentalnog plaka. U dentalnom plaku detektovano je više od 500 vrsta bakterija (92), međutim, samo neke od njih, pre svega Porphyromonas gingivalis, Tannerella forsythia, Prevotella intermedia i Aggregatibacter actinomycetemcomitans 
dovode se u vezu sa oboljenjima parodoncijuma (93). Iako je uloga mikroorganizama u nastanku parodontopatije od presudnog značaja, stepen destrukcije parodontalnih tkiva posledica je interakcije mikrobioloških faktora i imunog odgovora domaćina (94). Važnu ulogu imaju neke sistemske bolesti i faktori rizika, pre svega: pušenje, starost, genetika, pol i socioekonomski uslovi (95).

Da bi se mogao doneti zaključak da reaktivne kiseonične vrste (ROS) direktno utiču na nastanak nekog oboljenja Halliwell smatra da moraju biti ispunjeni sledeći uslovi $(96,97)$ :

-ROS ili oksidativno oštećenje moraju uvek biti prisutni na mestu povrede tkiva,

-Vreme formiranja ROS ili oksidativno oštećenje do kojeg dovodi mora se poklapati sa vremenom nastanka povrede tkiva,

-Direktna aplikacija ROS u određenom vremenskom intervalu i u koncentaciji koja je pronađena in vivo treba da dovede do istog oksidativnog oštećenja tkiva,

-Uklanjanje ROS ili sprečavanje njihovog nastanka, trebalo bi da umanji oštećenje tkiva u meri stepena inhibicije oksidativng oštećenja izazvano ROS.

Ovi uslovi odnose se na situaciju kada se ROS nalazi u dovoljno velikim količinama da izazovu direktno oštećenje tkiva i svakako nisu zadovoljeni kada su u pitanju parodontopatije. Međutim, ROS mogu učestvovati u oštećenju tkiva i indirektno kroz redoks-osetljive signalne puteve (98).

Poznato je da su polimorfonuklearni leukociti (PML) glavne odbrambene ćelije tkiva usne duplje koje je štite od štetnog delovanja oralnih bakterija. Interakcijom ovih leukocita i bakterija pokreću se različiti odbrambeni biohemijski i fiziološki procesi domaćina koji dovode do uništavanja patogena ali i do mogućeg oštećenja okolnog tkiva. Polimorfonuklearni leukociti, indukovani patogenima, karakterišu se povećanom potrošnjom kiseonika i u njima se dešava tzv. „respiratorna eksplozija“ (respiratory burst) koja ima za posledicu povećanu produkciju slobodnih radikala, kojim ove ćelije uništavaju bakterije. Međutim, tokom ove odbrambene reakcije može doći i do oksidativne modifikacije različitih biomolekula i oštećenja lokalnog tkiva, kao neka vrsta kolateralne štete (99-103). Prekomerna proizvodnja ROS, pre svega u PNL, izaziva neselektivno oštećenje ćelija, lipida ćelijske membrane, molekula DNK, i proteina kao i komponenata 
ekstracelularnog matriksa parodoncijuma (104). Istraživanja pokazuju da ROS mogu oštetiti proteoglikane, njihove konstituente glikoproteoglikane uključujući i hijaluron i kolagen $(104,105)$.

Povećana lokalna razgradnja kolagena kod parodontopatije utvrđena je prisustvom njegovih metabolita u gingivalnoj tečnosti (106). ROS mogu imati različite efekte na kolagen tipa I in vitro, uključujući fragmentaciju, polimerizaciju kao i oksidativnu modifikaciju, čineći molekul više sklon proteolizi $(105,107)$. Iako je prisustvo metabolita kolagena verovatno rezultat kombinacije dejstva proteolize od strane domaćina i bakterijske kolagenaze, oksidativno oštećenje može imati direktan ili indirektan doprinos u njegovoj razgradnji. Pored toga što kolagen može biti direktno napadnut od strane ROS, on može stupati u interakcije sa proizvodima lipidne peroksidacije, dovodeći do značajno izmenjene funkcije fibroblasta (108). Osim toga, rezultati studija pokazuju da oksidativne promene kolagena unutar parodontalnog tkiva mogu usporiti migraciju neutrofila što može biti veoma važan faktor u patogenezi parodontopatije (109). Kao bitan faktor u patogenezi parodontopatije navodi se i uloga ROS u oštećenju inhibitora tkivne matriks mataloproteinaze (110).

Iako efekti ROS na resorpciju kosti kod pacijenata sa parodontopatijom nisu direktno ispitivani, utvrđeno je da neke kiseonične vrste (superoksid i vodonik peroksid) mogu dovesti do stvaranja (111) i aktivacije osteoklasta (112,113). Moguću ulogu ROS u resorpciji kosti kod parodontopatije podržava i nalaz da hidroksil radikal i u manjoj meri vodonik peroksid mogu modifikovati strukturu proteoglikana alveolarne kosti in vitro (114).

Isto tako ROS dovodi do aktivacije citokina (npr. TNFa i IL-1), hemokina (npr.IL8) i ćelijskih adhezionih molekula. Faktori transkripcije NF-kB i AP-1 su redoks osetljivi i ROS menjaju njihovu aktivnost. I na kraju veruje se da ROS ubrzava apoptozu ćelija oštećenjem DNK od strane nitroksil radikala (NO•).

Sa druge strane, parodontopatija kao hronično inflamatorno oboljenje praćeno destrukcijom parodontalnih tkiva i sama dovodi do povećane produkcije ROS. Istraživanja pokazuju da se kod pacijenata sa parodontopatijom povećava koncentracija slobodnih radikala kao što su $\mathrm{H}_{2} \mathrm{O}_{2}, \mathrm{HOO}$ i $\mathrm{NO} \bullet(98,112)$. 
Pored toga, istraživanja pokazuju da parodontopatija ne samo da povećava količinu slobodnih radikala $u$ gingivalnoj tečnosti i pljuvački nego i smanjuje količinu antioksidativnih materija. Kod pacijenata sa parodontopatijom registrovano je smanjenje kako enzimskih tako $\mathrm{i}$ neenzimskih antioksidanata verovatno kao rezultat njihovog povećanog utroška zbog neutralisanja slobodnih radikala (115,116-122). Chapple i sar. $(123,124)$ navode da je i totalni antioksidativni kapacitet (TAOC) u gingivalnoj tečnosti i pljuvački značajno niži kod pacijenata sa parodontopatijom u odnosu na zdrave.

Nesklad u produkciji slobodnih radikala $\mathrm{i}$ antioksidativnoj zaštiti dovodi do oksidativnog stresa u usnoj duplji. Studije pokazuju da je u gingivalnoj tečnosti i pljuvački pacijenata sa parodontopatijom značajno veća koncentracija produkata oksidativne modifikacije proteina i DNK kao i krajnjih produkata lipidne peroksidacije u odnosu na pacijente sa zdravim parodoncijumom (125-134,115), da vrednosti markera oksidativnog oštećenja u pljuvački koreliraju sa stepenom oštećenja parodoncijuma (130-131), te da se smanjuju nakon parodontološke terapije $(128,129,133)$.

Novija pak ispitivanja pokazuju da parodontopatiju ne prati samo poremećaj u redoks ravnoteži lokalno u usnoj duplji, već da reaktivni oblici kiseonika proizvedeni tokom parodontopatije difunduju u krv dovodeći do oksidacije biomolekula krvi i nastanka cirkulatornog oksidativnog stresa sa svim negativnim posledicama (135). Poslednjih godina sve veći značaj se pridaje okidativnom stresu kod parodontopatije kao potencijalnom faktoru rizika u nastanku nekih sistemskih bolesti. Ispitivanja vršena na laboratorijskim životinjama pokazuju da eksperimentalno izazvana parodontopatija može da dovede do oksidativnog oštećenja jetre, povećavajući oksidativni stres u krvi $(89,132,136-138)$, te da oksidativni stres izazvan oštećenjem parodoncijuma učestvuje u nastanku ateroskleroze kod laboratorijskih životinja (139).

Isto tako, neki autori nalaze povišene vrednosti pojedinih markera oksidativnog stresa u krvi pacijenata sa parodontopatijom (140,141), dok Baltacioglu i sar. i Akalin i sar. ukazuju na značajno viši ukupan oksidativni stres u krvi pacijenata sa parodontopatijom u odnosu na zdrave ispitanike $(142,126)$. Međutim, ovakvih istraživanja je još uvek malo a njihovi rezultati su često suprotstavljeni i nedovoljno jasno formulisani da bi se mogli izvesti pravilni zaključci. Istovremeno ovi nalazi su potencijalno značajni i 
zahtevaju dalja istraživanja jer cirkulatorni oksidativni stres prouzrokovan hroničnim oboljenjima (kao što je parodontopatija) može vremenom oštetiti udaljena tkiva i organe i biti štetan za sistemsko zdravlje (135). 


\section{CILJEVI ISTRAŽIVANJA}

Ciljevi ovog istraživanja bili su sledeći:

1. Uporediti stepen oksidativnog stresa $u$ pljuvački $u$ grupi pacijenata sa parodontopatijom i u grupi pacijenata sa zdravim parodoncijumom

2. Uporediti stepen oksidativnog stresa u krvi u grupi pacijenata sa parodontopatijom i u grupi pacijenata sa zdravim parodoncijumom

3. Ispitati uticaj kauzalne terapije parodontopatije na stepen oksidativnog stresa $u$ pljuvački kod pacijenata sa parodontopatijom

4. Ispitati uticaj kauzalne terapije parodontopatije na stepen oksidativnog stresa $\mathrm{u}$ krvi kod pacijenata sa parodontopatijom 


\section{RADNE HIPOTEZE}

1. Pacijenti sa parodontopatijom imaju više vrednosti markera oksidativnog stresa u pljuvački od pacijenata sa zdravim parodoncijumom

2. Pacijenti sa parodontopatijom imaju više vrednosti markera oksidativnog stresa u krvi od pacijenata sa zdravim parodoncijumom

3. Kauzalna terapija parodontopatije utiče na smanjenje vrednosti markera oksidativnog stresa u pljuvački kod pacijenata sa parodontopatijom

4. Kauzalna terapija parodontopatije utiče na smanjenje vrednosti markera oksidativnog stresa u krvi kod pacijenata sa parodontopatijom 


\section{MATERIJAL I METODE}

Istraživanje je sprovedeno na Klinici za Stomatologiju Vojvodine i Klinici za infektivne bolesti Kliničkog centra Vojvodine u Novom Sadu u periodu od oktobra 2011. do maja 2013. godine i u njemu su učestvovali pacijenti koji su se javili na pregled na Kliniku za Stomatologiju Vojvodine.

Kriterijumi za uključenje pacijenata u eksperimentalnu grupu bili su sledeći:

- da boluju od hronične parodontopatije

- da su stariji od 18 godina

- da su sistemski zdravi

- da imaju najmanje 20 zuba.

Kriterijumi za uključenje pacijenata u kontrolnu grupu bili su sledeći:

- da imaju klinički zdrav parodoncijum

- da su stariji od 18 godina

- da su sistemski zdravi

- da imaju najmanje 20 zuba.

Kriterijumi za isključenje iz istraživanja bili su sledeći:

- parodontološka terapija u poslednjih 6 meseci

- korišćenje antibiotika u poslednja 3 meseca

- korišćenje bilo koje vrste vitaminsko-mineralne suplementacije

- trudnoća

- promena zdravstvenog stanja tokom istraživanja

- promena stila života tokom istraživanja - načina ishrane, životnih navika, upotreba medikamenata koji nisu korišćeni pre uključivanja u istraživanje.

Od 37 pacijenata sa parodontopatijom koji su ispunjavali kriterijume i pristali da učestvuju u istraživanju, tokom njegovog trajanja 4 ispitanika su isključena zbog upotrebe antibiotika, dok su tri ispitanika isključena zbog nedolaska na kontrolni pregled. Preostalih 30 pacijenata činilo je eksperimentalnu grupu ovog istraživanja-grupu A. Kontrolnu grupu -grupu B činilo je 20 pacijenata, bez oboljenja potpornog aparata zuba, komparabilnih po 
polu, starosti i navici pušenja sa ispitanicima u grupi sa parodontopatijom. Opšte karakteristike ispitanika prikazane su u tabeli 2.

Tabela 2. Opšte karakteristike ispitanika

\begin{tabular}{|c|c|c|c|}
\hline & $\begin{array}{c}\text { Grupa A } \\
(n=30)\end{array}$ & $\begin{array}{c}\text { Grupa B } \\
(n=20)\end{array}$ & p vrednost \\
\hline $\begin{array}{c}\text { Pol; n(\%) } \\
\text { Muški } \\
\text { Ženski }\end{array}$ & $\begin{array}{l}10(33,3 \%) \\
20(66,7 \%)\end{array}$ & $\begin{array}{r}9(45 \%) \\
11(55 \%)\end{array}$ & 0,553 \\
\hline $\begin{array}{l}\text { Starost; Godine } \\
(\bar{X} \pm \text { SD })\end{array}$ & $48,70 \pm 9,68$ & $46,25 \pm 9,25$ & 0,472 \\
\hline $\begin{array}{l}\text { Broj prisutnih } \\
\text { zuba; } \\
(\bar{X} \pm \text { SD })\end{array}$ & $22,54 \pm 2,14$ & $25,34 \pm 3,94$ & 0,487 \\
\hline $\begin{array}{c}\text { Pušenje; n( } \mathbf{0}) \\
\text { Pušači } \\
\text { Nepušaci }\end{array}$ & $\begin{array}{l}10(33,3 \%) \\
20(66,7 \%)\end{array}$ & $\begin{array}{c}7(35 \%) \\
13(65 \%)\end{array}$ & 1,000 \\
\hline
\end{tabular}

grupa A-pacijenti sa parodontopatijom

grupa $B$ - zdravi pacijenti

Pacijenti su u pismenoj formi informisani o sadržaju istraživanja i načinu upotrebe dobijenih rezultata, nakon čega su potpisali saglasnost za učešće. Istraživanje je odobreno od strane Etičke komisije Medicinskog fakulteta u Novom Sadu kao i od strane Etičke komisije Klinike za Stomatologiju Vojvodine. 


\subsection{KLINIČKO ISPITIVANJE}

Klinička procena stanja parodoncijuma vršena je na svim prisutnim zubima, izuzev trećih molara. Za procenu stanja parodoncijuma korišćeni su: plak indeks (PI), gingivalni indeks (GI), indeks krvarenja (IK), dubina sodniranja (DS) i nivo pripojnog epitela (NPE).

\section{Plak indeks -PI (Silness-Löe)(143)}

Količina dentalnog plaka u gingivalnoj trećini krunice zuba ispitana je stomatološkom sondom na četiri strane zuba (buko-distalna, bukalna, buko-mezijalna i oralna strana) i izražena je u bodovima na sledeći način:

0- nema plaka u gingivalnoj trećini krunice zuba

1- tanak sloj plaka u predelu ivice gingive koji se ne vidi a otkriva se povlačenjem vrha sonde preko ovog regiona

2- umerena količina plaka koja se može uočiti golim okom

3- velika količina dentalnog plaka koja se lako uočava inspekcijom

Izračunavanje prosečnog plak indeksa osobe vršeno je tako što su sabrane pojedinačne vrednosti indeksa i dobijeni zbir podeljen sa brojem pregledanih zuba i brojem pregledanih površina.

\section{Gingivalni indeks - GI (Löe-Silness) (144)}

Ispitivanje stepena inflamacije gingive vršeno je u predelu četiri strane zuba (bukodistalna, bukalna, buko-mezijalna i oralna strana). Stanje gingive izraženo je u bodovima na sledeći način:

0- zdrava gingiva

1- blaga inflamacija- minimalno crvenilo i neznatan otok gingive 
2- umerena inflamacija- jasno vidljivo crvenilo i otok gingive

3- jaka inflamacija- jako izraženo crvenilo i otok gingive

Izračunavanje prosečnog gingivalnog indeksa osobe vršeno je tako što su sabrane pojedinačne vrednosti indeksa i dobijeni zbir podeljen sa brojem pregledanih zuba i sa brojem pregledanih površina.

\section{Indeks krvarenja papile - IK (Mühlemann) (145)}

Ispitivanje stepena krvarenja gingive vršeno je provociranjem krvarenja interdentalne papile parodontalnom sondom po Williams-u (Hu-Friedy, SAD). Sondiran je prvo distalni, a zatim i mezijalni deo gingivalnog sulkusa, i to od baze papile do njenog vrha.

Kriterijumi za bodovanje bili su sledeći:

0 - nema krvarenja nakon sondiranja

1 - nakon sondiranja prisutno je tačkasto krvarenje

2 - nakon sondiranja prisutno je linijsko krvarenje

3 - gingivalni sulkus ispunjen krvlju

4 - krv se preliva van gingivalnog sulkusa

Intenzitet krvarenja posmatran je u periodu od 15 sekundi, i to u prvom i trećem kvadrantu sa bukalne, a u drugom i četvrtom kvadrantu sa oralne strane. Za izračunavanje prosečnog indeksa krvarenja gingive jedne osobe, sabirane su pojedinačne vrednosti indeksa za svaku papilu i dobijeni zbir je podeljen sa ukupnim brojem pregledanih interdentalnih papila ispitanika. 


\section{Dubina sondiranja (DS)}

Dubina sondiranja predstavlja rastojanje od ivice gingive do dna parodontalnog džepa, gingivalnog džepa ili gingivalnog sulkusa. Merenje ove vrednosti vršeno je parodontalnom sondom graduisanom po Williams-u (Hu-Friedy, SAD) u četiri tačke na svakom prisutnom zubu (sredina bukalne strane zuba, buko-mezijalni brid krunice, bukodistalni brid krunice i sredina oralne strane zuba). Vrednosti su izražene u milimetrima. Srednje vrednosti dubine sondiranja za svaku osobu dobijene su sabiranjem izmerenih vrednosti i deljenjem dobijenog zbira sa brojem pregledanih zuba i brojem pregledanih površina.

\section{Nivo pripojnog epitela (NPE)}

Nivo pripojnog epitela predstavlja rastojanje od gleđno-cementne granice do dna parodontalnog džepa. Merenje ove vrednosti vršeno je parodontalnom sondom graduisanom po Williams-u (Hu-Friedy, SAD) u četiri tačke na svakom prisutnom zubu (sredina bukalne strane zuba, buko-mezijalni brid krunice, buko-distalni brid krunice i sredina oralne strane zuba). Vrednosti su izražene u milimetrima. Srednje vrednosti nivoa pripojnog epitela za svaku osobu dobijene su sabiranjem izmerenih vrednosti i deljenjem dobijenog zbira sa brojem pregledanih zuba i brojem pregledanih površina.

Kod ispitanika eksperimentalne grupe je sprovedena kauzalna terapija parodontopatije: identifikacija dentalnog plaka, motivacija i obuka pacijenata pravilnom održavanju oralne higijene, uklanjanje dentalnog plaka i zubnog kamenca ultrazvučnim aparatom (Mini Piezon, EMS, Switzerland) i uklanjanje subgingivalnih naslaga i obrada površine korena zuba specijalnim Gracey kiretama (Kohler, Austria). Klinička procena stanja parodoncijuma urađena je na početku ispitivanja i 3 meseca nakon završetka parodontološke terapije. 


\subsection{LABORATORIJSKO ISPITIVANJE}

Laboratorijsko ispitivanje se sastojalo iz određivanja markera oksidativnog stresa u pljuvački i krvi pacijenata. Kao markeri oksidativnog stresa u obe tečnosti korišćeni su marker oksidativnog oštećenja DNK-8-hidroksideoksiguanozin (8-OHdG), marker oštećenja lipida-malondialdehid (MDA) i antioksidativni enzim-superoksid-dismutaza (SOD).

Za određivanje vrednosti 8-OHdG u pljuvački i krvi korišćen je komercijalni imunoenzimski ELISA test (Cell Biolabs' OxiSelect ${ }^{\mathrm{TM}}$, USA). OxiSelect Oxidative DNA Damage ELISA test je kompetitivna ELISA tehnika za kvantitativno merenje 8-OHdG. Nepoznati uzorci i standardi sa poznatom koncentracijom nanose se na ploču koja je obložena sa 8-OHdG/BSA konjugatom. Nakon toga se dodaju anti-8-OHdG monoklonska antitela i potom HRP konjugovana sekundarna antitela. Koncentracije 8-OHdG u nepoznatom uzorku određuju se prema krivulji koja se pravi na osnovu očitanih spektrofotometrijskih talasnih dužina za poznate standarde.

Za određivanje vrednosti MDA u pljuvački i krvi korišćen je komercijalni imunoenzimski ELISA test (Cell Biolabs' OxiSelect ${ }^{\mathrm{TM}}$, USA) po proceduri propisanoj od strane proizvodjača. Rezultat se čita spektrofotometrijski prema standardnoj krivoj od 0$120 \mathrm{pmol} / \mathrm{mg}$.

Koncetracija i aktivnost SOD u pljuvački i krvi određeni su komercijalnim imunoenzimskim ELISA testom (Cell Biolabs' OxiSelect $^{\mathrm{TM}}$, USA), po proceduri propisanoj od strane proizvodjača spektrofotometrijskom metodom. Vrednosti se očitavaju prema vrednostima standardne krive kvantitativno $(5 \mathrm{U} / \mu \mathrm{l}$ do $0,61 \mathrm{mU} / \mu \mathrm{l})$ i u smislu procenta aktivnosti ovog enzima na osnovu preporučene formule proizvođača.

Sva tri korišćena testa su namenjena samo u istraživačke svrhe.

Kod pacijenata eksperimentalne grupe pljuvačka i krv su uzeti tokom prve posete, pre parodontološke terapije, kao i tri meseca posle završene terapije. Kod pacijenata kontrolne grupe pljuvačka i krv su uzeti jednokratno tokom prve posete. 


\subsubsection{Određivanje markera oksidativnog stresa u pljuvački}

Određivanje markera oksidativnog stresa vršeno je u mešovitoj nestimulisanoj pljuvački. Pacijentima je rečeno da ne piju, ne jedu i ne puše pre uzimanja uzoraka. Uzorci

pljuvačke su centrifugirani na 3000 obrtaja u trajanju od 10 minuta nakon čega je supernatant izdvojen i čuvan na $-80^{\circ} \mathrm{C}$ do analize. Analiza uzoraka vršena je na Klinici za infektivne bolesti Kliničkog centra Vojvodine.

\subsubsection{Određivanje markera oksidativnog stresa u krvi}

Određivanje markera oksidativnog stresa vršeno je u kapilarnoj krvi. Uzorci krvi iz prsta uzeti su pomoću posebnih epruveta obloženih antikoagulansom EDTA (Kabe Labotechnik, Germany). Uzorci krvi su centrifugirani na 3000 obrtaja u trajanju od 10 minuta nakon čega je plazma izdvojena i čuvana na $-80^{\circ} \mathrm{C}$ do analize. Analiza uzoraka vršena je na Klinici za infektivne bolesti Kliničkog centra Vojvodine.

\subsection{STATISTIČKA OBRADA PODATAKA}

Podaci prikupljeni tokom istraživanja su analizirani korišćenjem statističkog paketa SPSS 16 for Windows.

Metode deskriptivne statistike upotrebljene su za određivanje:

- mere centralne tendencije (aritmetička sredina);

- mere varijabiliteta (standardna devijacija) kod numeričkih obeležja.

Metode komparativne statistike obuhvatile su:

- Pirsonov $\chi^{2}$ test i Fišerov test za testiranje (ne)zavisnosti pojedinih parova posmatranih atributivnih obeležja (pol, pušenje); 
- t-test za utvrđivanje razlike srednjih vrednosti kod numeričkih obeležja (godine starosti, broj prisutnih zuba, parodontološki indeksi, poređenje indeksa pre i posle terapije, uspeh terapije, stepen oksidativnog stresa) između dve grupe ispitanika;

- Mann-Whitney za utvrđivanje razlike srednjih vrednosti kod numeričkih obeležja (stepen oksidativnog stresa) između dve grupe ispitanika;

- Wilcoxon test za poređenje markera oksidativnog stresa pre i posle terapije;

- Povezanost između dve varijable merena je Spearmanovim koeficijentom korelacije;

- U cilju procene uticaja stanja parodoncijuma na markere oksidativnog stresa pacijenti su kategorisani prema stepenu inflamacije na one sa izraženom i na one sa umerenom inflamacijom, prema dubini sondiranja na one sa $\mathrm{DS} \geq 5 \mathrm{~mm}<20 \%$ i na one sa $\mathrm{DS} \geq 5 \mathrm{~mm} \geq 20 \%$, prema nivou pripojnog epiela na one sa $\mathrm{NPE} \geq 3 \mathrm{~mm}$ i na one sa NPE $<3 \mathrm{~mm}$. Za utvrđivanje razlike srednjih vrednosti kod numeričkih obeležja između dve grupe ispitanika korišćen je t-test. Kako bi se procenio uticaj terapije na vrednosti markera oksidativnog stresa u navedenim grupama korišćen je Wilcoxon test;

- Za procenu uticaja pušenja na vrednosti markera oksidativnog stresa u grupi pušača i nepušača korišćen je t-test, dok su efekti terapije u ovim grupama poređeni Wilcoxon testom.

U svim primenjenim testovima, rezultati kod kojih je nivo značajnosti bar $95 \%$ $(p<0,05)$ tumačeni su kao statistički značajni, a oni sa nivoom značajnosti minimalno 99\% $(\mathrm{p}<0,01)$ kao statistički visoko značajni. Rezultati kod kojih je nivo značajnosti ispod 95\% $(\mathrm{p} \geq 0,05)$ interpretirani su kao rezultati bez statističkog značaja.

Rezultati su prezentovani tekstualno, tabelarno i grafički. 


\section{REZULTATI}

\subsection{REZULTATI KLINIČKOG ISPITIVANJA}

\subsubsection{Parodontološki parametri kod pacijenata sa parodontopatijom pre terapije}

$\mathrm{Na}$ početku istraživanja, pre sprovedene kauzalne terapije vrednosti plak indeksa $\mathrm{u}$ grupi pacijenata sa parodontopatijom kretale su se $u$ intervalu od 0,83 do 1,97 dok je srednja vrednost ovog parametara iznosila 1,40. Srednja vrednost gingivalnog indeksa bila je 1,79 (od 1,08 do 2,79) a indeksa krvarenja gingive 1,57 (od 0,64 do 3,47). Srednja vrednost dubina sondiranja iznosila je 3,14 mm, sa intervalom od 2,27 mm do 4,42 mm. Vrednosti nivoa pripojnog epitela na početku istraživanja kretale su se $\mathrm{u}$ širokom intervalu, od 0,76 $\mathrm{mm}$ do 5,50 $\mathrm{mm}$, a srednja vrednost iznosila je 2,70 $\mathrm{mm}$ (Tabela 3).

Tabela 3. Parodontološki parametri kod pacijenata sa parodontopatijom pre terapije

\begin{tabular}{cccccc}
\hline Indeks & $\bar{X}$ & SD & SG & Minimum & Maksimum \\
\hline PI & 1,40 & 0,43 & 0,07 & 0,83 & 1,97 \\
GI & 1,79 & 0,64 & 0,09 & 1,08 & 2,79 \\
IK & 1,57 & 0,81 & 0,13 & 0,64 & 3,47 \\
DS & 3,14 & 0,56 & 0,10 & 2,27 & 4,42 \\
NPE & 2,70 & 1,03 & 0,19 & 0,76 & 5,50 \\
\hline
\end{tabular}




\subsubsection{Parodontološki parametri kod zdravih pacijenata}

Kod pacijenata sa zdravim parodoncijumom srednja vrednost plak indeksa iznosila je 0,32, sa rasponom od 0,04 do 1,01. Srednja vrednost gingivalnog indeksa bila je 0,19 (od 0,00 do 0,50) a indeksa krvarenja gingive 0,28 (od 0,00 do 1,78). Interval vrednosti dubine sondiranja bio je od 1,13 $\mathrm{mm}$ do $1,71 \mathrm{~mm}$, a srednja vrednost ovog indeksa iznosila je 1,45 mm. Nivo pripojnog epitela imao je raspon od 0,02 $\mathrm{mm}$ do 1,09 $\mathrm{mm}$, sa srednjom vrednosti od $0,43 \mathrm{~mm}$ (Tabela 4)

Tabela 4. Parodontološki parametri kod zdravih pacijenata

\begin{tabular}{cccccc}
\hline Indeks & $\bar{X}$ & SD & SG & Minimum & Maksimum \\
\hline PI & 0,32 & 0,28 & 0,06 & 0,04 & 1,01 \\
GI & 0,19 & 0,37 & 0,08 & 0,00 & 0,50 \\
IK & 0,28 & 0,39 & 0,09 & 0,00 & 1,78 \\
DS & 1,45 & 0,18 & 0,04 & 1,13 & 1,71 \\
NPE & 0,43 & 0,56 & 0,12 & 0,00 & 1,09 \\
\hline
\end{tabular}


5.1.3. Analiza razlike parodontoloških parametara kod pacijenata sa parodontopatijom pre terapije i zdravih pacijenata

Analizom dobijenih podataka konstatuje se da su se pacijenti sa parodontopatijom (grupa A) i zdravi ispitanici (grupa B) na početku istraživanja statistički značajno razlikovali u svim ispitivanim kliničkim parametrima: količini prisutnog dentalnog plaka (PI), inflamaciji gingive (GI), intenzitetu krvarenja (IK), dubini sondiranja (DS) i nivou pripojnog epitela (NPE) (Grafikon 1, Tabela 5).

Grafikon 1. Parodontološki parametri kod pacijenata sa parodontopatijom (grupa A) pre terapije i zdravih pacijenata (grupa B), a-PI, GI i IK, b-DS i NPE

a

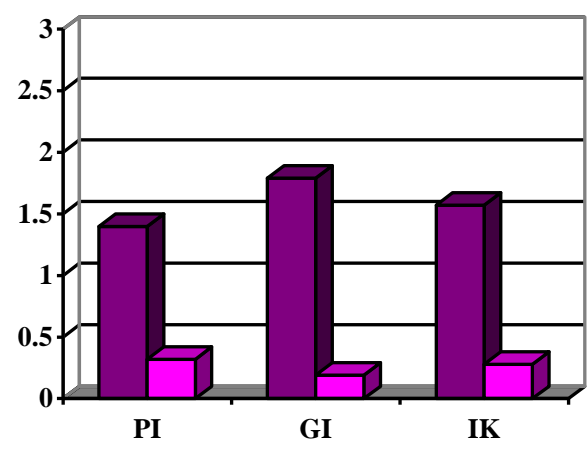

$\square$ grupa A $\square$ grupa B b

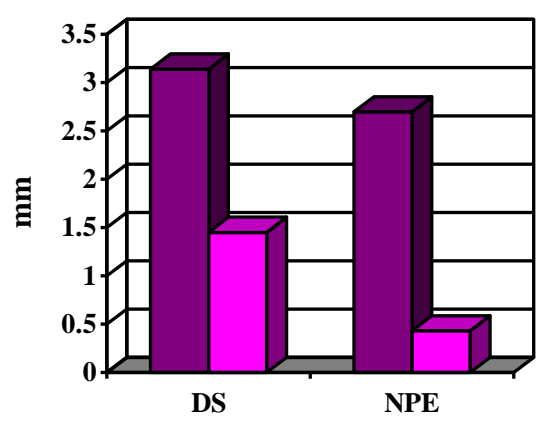

$\square$ grupa A $\square$ grupa B 
Tabela 5. Značajnost razlike parodontoloških parametara kod pacijenata sa parodontopatijom (grupa A) pre terapije i zdravih pacijenata (grupa B)

\begin{tabular}{lcccc}
\hline & Grupa A & Grupa B & & \\
& $(\bar{X} \pm$ SD $)$ & $(\bar{X} \pm$ SD $)$ & & $\mathrm{p}$ \\
\hline PI & $1,40 \pm 0,43$ & $0,32 \pm 0,28$ & 5,814 & $\mathbf{0 , 0 0 0}$ \\
GI & $1,79 \pm 0,64$ & $0,19 \pm 0,37$ & 4,202 & $\mathbf{0 , 0 0 0}$ \\
IK & $1,57 \pm 0,81$ & $0,28 \pm 0,39$ & 5,751 & $\mathbf{0 , 0 0 0}$ \\
DS $(\mathrm{mm})$ & $3,14 \pm 0,56$ & $1,45 \pm 0,18$ & 13,088 & $\mathbf{0 , 0 0 0}$ \\
NPE $(\mathrm{mm})$ & $2,70 \pm 1,03$ & $0,43 \pm 0,56$ & 9,031 & $\mathbf{0 , 0 0 0}$ \\
\hline
\end{tabular}

\subsubsection{Parodontološki parametri kod pacijenata sa parodontopatijom posle terapije}

Posle terapije srednja vrednost plak indeksa iznosila je 0,35 , gingivalnog indeksa 0,25, indeksa krvarenja 0,71, dubine sondiranja 2,59 $\mathrm{mm}$, dok je srednja vrednost nivoa pripojnog epitela bila 2,19 $\mathrm{mm}$ (Tabela 6). 
Tabela 6. Parodontološki parametri kod pacijenata sa parodontopatijom posle terapije

\begin{tabular}{cccccc}
\hline Indeks & $\bar{X}$ & SD & SG & Minimum & Maksimum \\
\hline PI & 0,35 & 0,22 & 0,40 & 0,08 & 1,12 \\
GI & 0,25 & 0,33 & 0,60 & 0,02 & 1,31 \\
IK & 0,71 & 0,43 & 0,80 & 0,08 & 1,73 \\
DS & 2,59 & 0,45 & 0,80 & 1,95 & 3,81 \\
NPE & 2,19 & 0,87 & 0,12 & 0,59 & 4,08 \\
\hline
\end{tabular}

\subsubsection{Analiza razlike parodontoloških parametara kod pacijenata sa parodontopatijom pre i posle terapije}

Dobijeni rezultati pokazuju statistički značajno smanjenje svih ispitivanih kliničkih parametara posle terapije. Tako je srednja vrednost plak indeksa smanjena za 1,04, gingivalnog indeksa za 1,54 i indeksa krvarenja za 0,86. Srednja vrednost dubine sondiranja smanjena je za $0,56 \mathrm{~mm}$ a nivoa pripojnog epitela za $0,51 \mathrm{~mm}$ (Grafikon 2, Tabela 7). 
Grafikon 2. Parodontološki parametri kod pacijenata sa parodontopatijom pre i posle terapije, a-PI, GI $i I K, b-D S$ i NPE

a

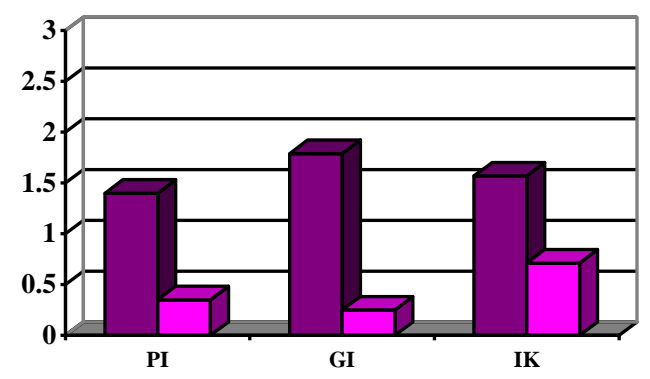

$\square$ Na početku $\square$ Posle terapije

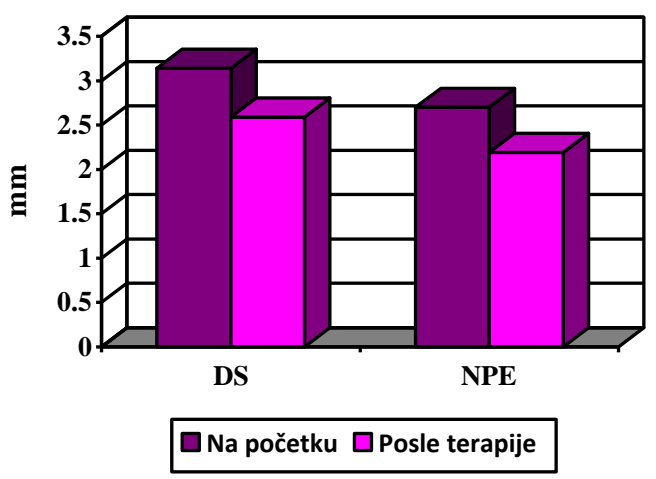

Tabela 7. Značajnost razlike parodontoloških parametara kod pacijenata sa parodontopatijom pre i posle terapije

\begin{tabular}{llllllll}
\hline & $\begin{array}{l}\text { Pre } \\
\text { terapije }\end{array}$ & $\begin{array}{l}\text { Posle } \\
\text { terapije }\end{array}$ & $\begin{array}{c}\Delta \text { razlika } \\
(\bar{X})\end{array}$ & SG & p & \multicolumn{2}{c}{ 95\% interval poverenja } \\
& $(\bar{X})$ & & & & & \\
donja granica & gornja granica \\
\hline PI & 1,40 & 0,35 & 1,04 & 0,07 & $\mathbf{0 , 0 0 0}$ & 0,897 & 1,192 \\
GI & 1,79 & 0,25 & 1,54 & 0,78 & $\mathbf{0 , 0 0 0}$ & 1,385 & 1,705 \\
IK & 1,57 & 0,71 & 0,86 & 0,11 & $\mathbf{0 , 0 0 0}$ & 0,630 & 1,096 \\
DS (mm) & 3,14 & 2,59 & 0,56 & 0,06 & $\mathbf{0 , 0 0 0}$ & 0,421 & 0,689 \\
NPE (mm) & 2,70 & 2,19 & 0,51 & 0,14 & $\mathbf{0 , 0 0 1}$ & 0,231 & 0,789
\end{tabular}


5.1.6. Analiza razlike parodontoloških parametara kod pacijenata sa parodontopatijom posle terapije i zdravih pacijenata

Dobijeni rezultati pokazuju da su srednje vrednosti PI i GI kod pacijenata sa parodontopatijom posle terapije sniženi na nivo koji je blizu srednjih vrednosti ovih indeksa kod zdravih pacijenata (PI-0,35 i 0,32, GI-0,25 i 0,19). Iako značajno smanjene posle terapije, srednje vednosti IK, DS i NPE i dalje su bile značajno više u odnosu na vrednost kod zdravih pacijenata (IK-0,71 i 0,28, DS-2,59 mm i 0,45 mm, NPE- 2,19 mm i 0,43 mm) (Grafikon 3, Tabela 8).

Grafikon 3. Parodontološki parametri kod pacijenata sa parodontopatijom (grupa A) posle terapije i zdravih pacijenata (grupa B), a-PI, GI i IK, b-DS i NPE

a

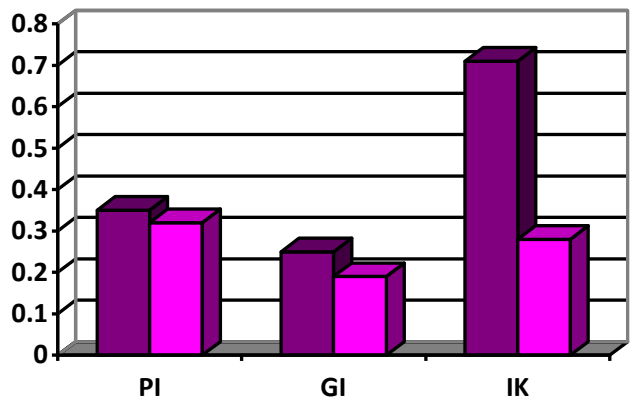

$\square$ grupa A $\square$ grupa B b

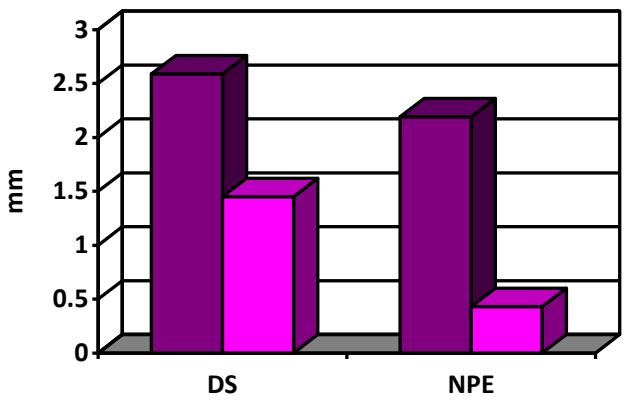

$\square$ grupa A $\square$ grupa B 
Tabela 8. Značajnost razlike parodontoloških parametara kod pacijenata sa parodontopatijom (grupa A) posle terapije i zdravih pacijenata (grupa B)

\begin{tabular}{lcccc}
\hline $\begin{array}{l}\text { Klinički } \\
\text { parametri }\end{array}$ & $\begin{array}{c}\text { Grupa A } \\
(\bar{X} \pm \text { SD) }\end{array}$ & $\begin{array}{c}\text { Grupa B } \\
(\bar{X} \pm \text { SD })\end{array}$ & t & p \\
\hline PI & $0,35 \pm 0,22$ & $0,32 \pm 0,28$ & 0,516 & 0,608 \\
GI & $0,25 \pm 0,33$ & $0,19 \pm 0,37$ & 0,550 & 0,585 \\
IK & $0,71 \pm 0,43$ & $0,28 \pm 0,39$ & 3,545 & $\mathbf{0 , 0 0 1}$ \\
DS (mm) & $2,59 \pm 0,45$ & $1,45 \pm 0,18$ & 12,354 & $\mathbf{0 , 0 0 0}$ \\
NPE (mm) & $2,19 \pm 0,87$ & $0,43 \pm 0,56$ & 6,163 & $\mathbf{0 , 0 0 0}$ \\
\hline
\end{tabular}

\subsection{REZULTATI LABORATORIJSKOG ISPITIVANJA}

Laboratorijsko ispitivanje je obuhvatalo određivanje markera oksidativnog stresa $\mathrm{u}$ pljuvački i krvi ispitanika. Marker oštećenja DNK (8-OHdG), lipidne peroksidacije (MDA) i antioksidativni enzim superoksid-dismutaza (SOD) su određeni kod pacijenata sa parodontopatijom na početku istraživanja i tri meseca posle terapije, dok su ovi markeri kod zdravih ispitanika određeni samo na početku istraživanja. 


\subsubsection{MARKERI OKSIDATIVNOG STRESA U PLJUVAČKI}

\subsubsection{Markeri oksidativnog stresa u pljuvački kod pacijenata sa parodontopatijom pre terapije}

Srednja vrednost 8-OHdG u pljuvački pacijenata sa parodontopatijom na početku istraživanja iznosila je $0,869 \mathrm{ng} / \mathrm{ml}$, sa opsegom vrednosti od 0,388 ng/ml do 2,100 ng/ml. Vrednosti MDA kretale su se u intervalu od $1,100 \mathrm{pmol} / \mu \mathrm{l}$ do $4,800 \mathrm{pmol} / \mu \mathrm{l}$ dok je njegova srednja vrednost iznosila $2,990 \mathrm{pmol} / \mu \mathrm{l}$. Srednja vrednost SOD pre parodontološke terapije iznosila je $0,156 \mathrm{U} / \mu \mathrm{l}$ (od 0,012 do 1,900) dok je srednja vrednost aktivnosti ovog markera bila $14,890 \%$ (od 2,000 do 39,930) (Tabela 9).

Tabela 9. Markeri oksidativnog stresa u pljuvački kod pacijenata sa parodontopatijom pre terapije

\begin{tabular}{llllll}
\hline & $\bar{X}$ & SD & SG & Minimum & Maksimum \\
\hline $\begin{array}{l}\text { 8-OHdG } \\
(\mathbf{n g} / \mathbf{m l})\end{array}$ & 0,869 & 0,494 & 0,090 & 0,388 & 2,100 \\
\hline $\begin{array}{l}\text { MDA } \\
(\mathbf{p m o l} / \boldsymbol{\mu l})\end{array}$ & 2,990 & 1,210 & 0,220 & 1,110 & 4,800 \\
\hline SOD & 0,156 & 0,391 & 0,071 & 0,012 & 1,900 \\
$(\mathbf{U} / \boldsymbol{\mu l})$ & & & 1,718 & 2,000 & 39,930 \\
\hline SOD $(\%)$ & 14,890 & 9,411 & & & \\
\hline
\end{tabular}




\subsubsection{Markeri oksidativnog stresa u pljuvački kod pacijenata sa zdravim parodoncijumom}

Srednja vrednost $8-\mathrm{OHdG}$ u pljuvački pacijenata sa zdravim parodoncijumom iznosila je $0,612 \mathrm{ng} / \mathrm{ml}$, sa opsegom vrednosti od $0,180 \mathrm{ng} / \mathrm{ml}$ do $1,275 \mathrm{ng} / \mathrm{ml}$. Vrednosti MDA kretale su se u intervalu od $0,230 \mathrm{pmol} / \mu \mathrm{l}$ do 3,700 pmol/ $\mu 1$, dok je njegova srednja vrednost iznosila $1,330 \mathrm{pmol} / \mu 1$. Srednja vrednost SOD iznosila je 0,022 U/ $\mu 1$ (od 0,001 do 0,046 ), dok je srednja vrednost aktivnosti ovog markera bila 7,581\% (od 0,000 do 17,800) (Tabela 10).

Tabela 10. Markeri oksidativnog stresa u pljuvački kod pacijenata sa zdravim parodoncijumom

\begin{tabular}{lccccc}
\hline & $\bar{X}$ & SD & SG & Minimum & Maksimum \\
\hline $\begin{array}{l}\text { 8-OHdG } \\
(\mathbf{n g} / \mathbf{m l})\end{array}$ & 0,612 & 0,460 & 0,103 & 0,180 & 1,275 \\
\hline MDA & 1,330 & 0,922 & 0,206 & 0,230 & 3,700 \\
$(\mathbf{p m o l} / \boldsymbol{\mu l})$ & 0,022 & 0,013 & 0,003 & 0,001 & 0,046 \\
\hline $\begin{array}{l}\text { SOD } \\
(\mathbf{U} / \boldsymbol{\mu l})\end{array}$ & 7,581 & 5,774 & 1,291 & 0,000 & 17,800 \\
\hline SOD $(\%)$ & & & & & \\
\hline
\end{tabular}




\subsubsection{Analiza razlike markera oksidativnog stresa kod pacijenata sa parodontopatijom pre terapije i zdravih pacijenata}

Analizom dobijenih podataka konstatuje se da su na početku istraživanja pacijenti sa parodontopatijom imali statistički značajno više srednje vrednosti svih ispitivanih markera oksidativnog stresa $u$ pljuvački $u$ odnosu na pacijente sa zdravim parodoncijumom. Tako je srednja vrednost 8-OHdG kod pacijenata sa parodontopatijom iznosila $0,869 \mathrm{ng} / \mathrm{ml}$, dok je srednja vrednost ovog markera kod zdravih pacijenata bila $0,612 \mathrm{ng} / \mathrm{ml}$. MDA je zabeležio srednju vrednost od 2,990 pmol/ $\mu \mathrm{l}$ u grupi sa parodontopatijom, a njegova srednja vrednost kod zdravih ispitanika je bila 1,330 pmol/ $\mu 1$. SOD je kod pacijenata sa parodontopatijom imao srednju vrednost $0,156 \mathrm{U} / \mu \mathrm{l}$ a njegova aktivnost je iznosila 14,890\%, dok su srednje vrednosti kod ispitanika sa zdravim

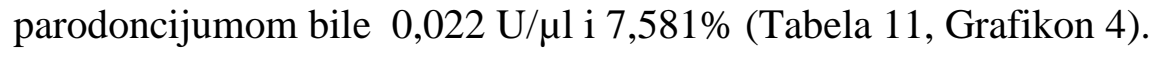

Tabela 11. Značajnost razlike markera oksidativnog stresa u pljuvački kod pacijenata sa parodontopatijom (grupa A) pre terapije i zdravih pacijenata (grupa B)

\begin{tabular}{lcccc}
\hline & Grupa A & Grupa B & \\
& $(\bar{X} \pm \mathrm{SD})$ & $(\bar{X} \pm \mathrm{SD})$ & & \\
\hline $\begin{array}{l}\text { 8-OHdG } \\
(\mathbf{n g} / \mathbf{m l})\end{array}$ & $0,869 \pm 0,494$ & $0,612 \pm 0,460$ & 3,400 & $\mathbf{0 , 0 4 3}$ \\
\hline MDA & & & \\
$(\mathbf{p m o l} / \boldsymbol{\mu l})$ & $2,990 \pm 1,210$ & $1,330 \pm 0,920$ & 5,226 & $\mathbf{0 , 0 0 0}$ \\
\hline SOD & & & & \\
$(\mathbf{U} / \boldsymbol{\mu l})$ & $0,156 \pm 0,391$ & $0,022 \pm 0,013$ & 2,336 & $\mathbf{0 , 0 0 2}$ \\
\hline SOD $(\%)$ & $14,890 \pm 9,411$ & $7,581 \pm 5,774$ & 3,100 & $\mathbf{0 , 0 0 3}$ \\
\hline
\end{tabular}




\subsubsection{Markeri oksidativnog stresa u pljuvački kod pacijenata sa parodontopatijom} posle terapije

Posle terapije, u pljuvački pacijenata sa parodontopatijom srednja vrednost 8OHdG iznosila je 0,618 ng/ml, MDA 2,140 pmol/ $\mu$, dok su srednje vrednosti SOD i $\%$ SOD bile $0,052 \mathrm{U} / \mu \mathrm{l}$ i $11,840 \%$ (Tabela 12 ).

Tabela 12. Markeri oksidativnog stresa u pljuvački kod pacijenata sa parodontopatijom posle terapije

\begin{tabular}{lccccc}
\hline & $\bar{X}$ & SD & SG & Minimum & Maksimum \\
\hline $\begin{array}{l}\text { 8-OHdG } \\
(\mathbf{n g} / \mathbf{m l})\end{array}$ & 0,618 & 0,380 & 0,069 & 0,246 & 1,425 \\
\hline $\begin{array}{l}\text { MDA } \\
(\mathbf{p m o l} / \boldsymbol{\mu l})\end{array}$ & 2,140 & 0,950 & 0,173 & 1,110 & 4,800 \\
\hline SOD & 0,052 & 0,047 & 0,009 & 0,016 & 0,138 \\
$(\mathbf{U} / \boldsymbol{\mu l})$ & 11,840 & 6,320 & 1,174 & 4,130 & 26,590 \\
\hline SOD $(\%)$ & & & & & \\
\hline
\end{tabular}

5.2.1.5. Analiza razlike markera oksidativnog stresa u pljuvački kod pacijenata sa parodontopatijom na pre i posle terapije

$\mathrm{Na}$ osnovu dobijenih podataka može se konstatovati da je nakon terapije $\mathrm{u}$ pljuvački pacijenata sa parodontopatijom zabeležen pad srednjih vrednosti svih ispitivanih markera oksidativnog stresa. Tako je srednja vrednost 8-OHdG statistički značajno 
smanjena za 0,251 ng/ml (p=0,000), dok je srednja vrednost MDA smanjena za 0,850 $\mathrm{pmol} / \mu \mathrm{l}(\mathrm{p}=0,000)$. Srednja vrednost SOD posle terapije smanjena je za $0,104 \mathrm{U} / \mu \mathrm{l}$ $(p=0,052)$, dok je vrednost aktivnosti ovog markera smanjena za 3,050\% $(p=0,053)$, što je blizu statističke značajnosti (Tabela 13, Grafikon 4).

Tabela 13. Značajnost razlike markera oksidativnog stresa u pljuvački kod pacijenata sa parodontopatijom pre i posle terapije

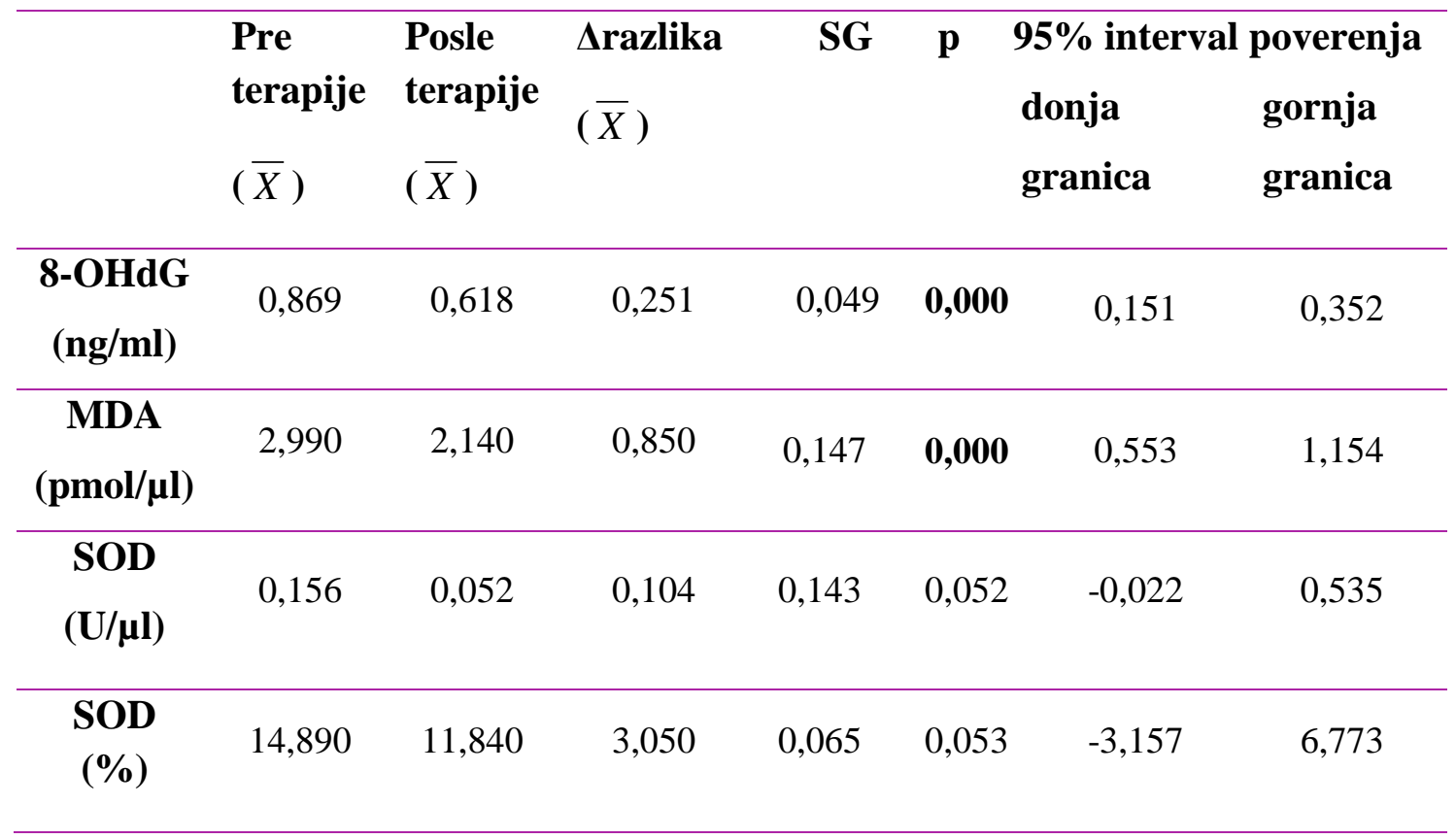

\subsubsection{Analiza razlike markera oksidativnog stresa u pljuvački kod pacijenata sa parodontopatijom posle terapije i zdravih pacijenata}

Poređenjem vrednosti markera oksidativnog stresa u pljuvački pacijenata sa parodontopatijom posle terapije sa vrednostima ovih markera kod zdravih pacijenata, može se konstatovati da je kauzalna terapija parodontopatije dovela do smanjenja 
vrednosti 8-OHdG na nivo koji je veoma blizu vrednosti ovog markera kod zdravih pacijenata. Naime, srednja vrednost ovog markera nakon terapije iznosila je 0,618 ng/ml, što je gotovo jednako srednjoj vrednosti kod zdravih pacijenata $(0,612 \mathrm{ng} / \mathrm{ml})$. Srednje vrednosti ostalih ispitivanih markera (MDA, SOD, \%SOD), iako smanjene nakon preduzete parodontološke terapije, bile su i dalje značajno više u odnosu na srednje vrednost kod zdravih pacijenata (Tabela 14, Grafikon 4).

Tabela 14. Značajnost razlike markera oksidativnog stresa u pljuvački kod pacijenata sa parodontopatijom (grupa A) posle terapije i zdravih pacijenata (grupa B)

\begin{tabular}{lclll}
\hline & $\begin{array}{c}\text { Grupa A } \\
(\bar{X} \pm \mathrm{SD})\end{array}$ & $\begin{array}{l}\text { Grupa B } \\
(\bar{X} \pm \mathrm{SD})\end{array}$ & $\mathrm{t}$ & \\
\hline $\begin{array}{l}\text { 8-OHdG } \\
(\mathbf{n g} / \mathbf{m l})\end{array}$ & $0,618 \pm 0,380$ & $0,612 \pm 0,460$ & 0,046 & 0,929 \\
\hline MDA & $2,140 \pm 0,950$ & $1,330 \pm 0,920$ & 2,988 & $\mathbf{0 , 0 0 4}$ \\
$(\mathbf{p m o l} / \boldsymbol{\mu l})$ & & & \\
\hline SOD & $0,052 \pm 0,047$ & $0,022 \pm 0,013$ & 2,938 & $\mathbf{0 , 0 0 5}$ \\
$(\mathbf{U} / \boldsymbol{\mu l})$ & & & \\
\hline SOD $(\%)$ & $11,841 \pm 6,320$ & $7,580 \pm 5,771$ & 2,404 & $\mathbf{0 , 0 2 0}$ \\
\hline
\end{tabular}


Grafikon 4. Markeri oksidativnog stresa u pljuvački kod pacijenata sa parodontopatijom (grupa A) pre i posle terapije i zdravih pacijenata (grupa B);

(a) 8-OHdG, (b) MDA, (c) SOD i (d) \%SOD

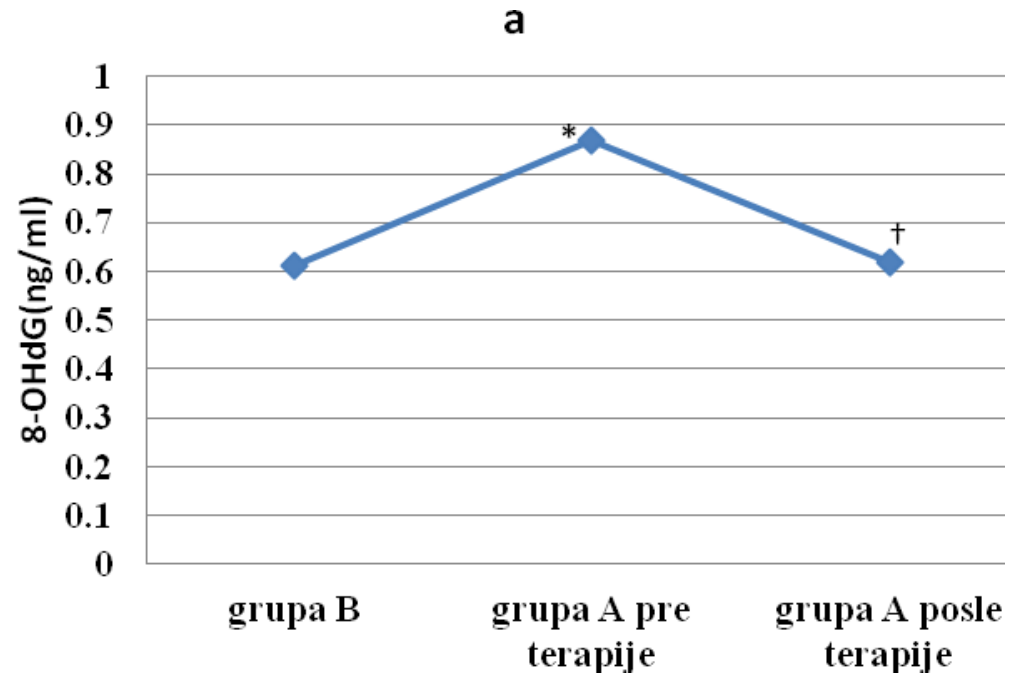

* statistički značajna razlika u odnosu na vrednost kod zdravih pacijenata $\dagger$ statistički značajna razlika u odnosu na vrednost pre terapije

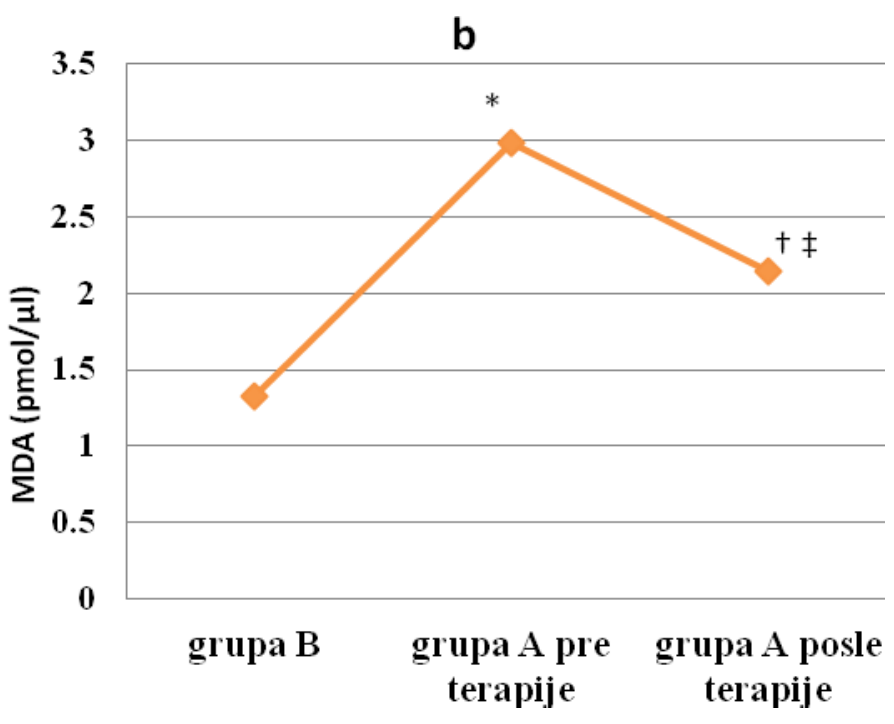

* statistički značajna razlika u odnosu na vrednost kod zdravih pacijenata $\dagger$ statistički značajna razlika u odnosu na vrednost pre terapije † statistički značajna razlika u odnosu na vrednost kod zdravih pacijenata 

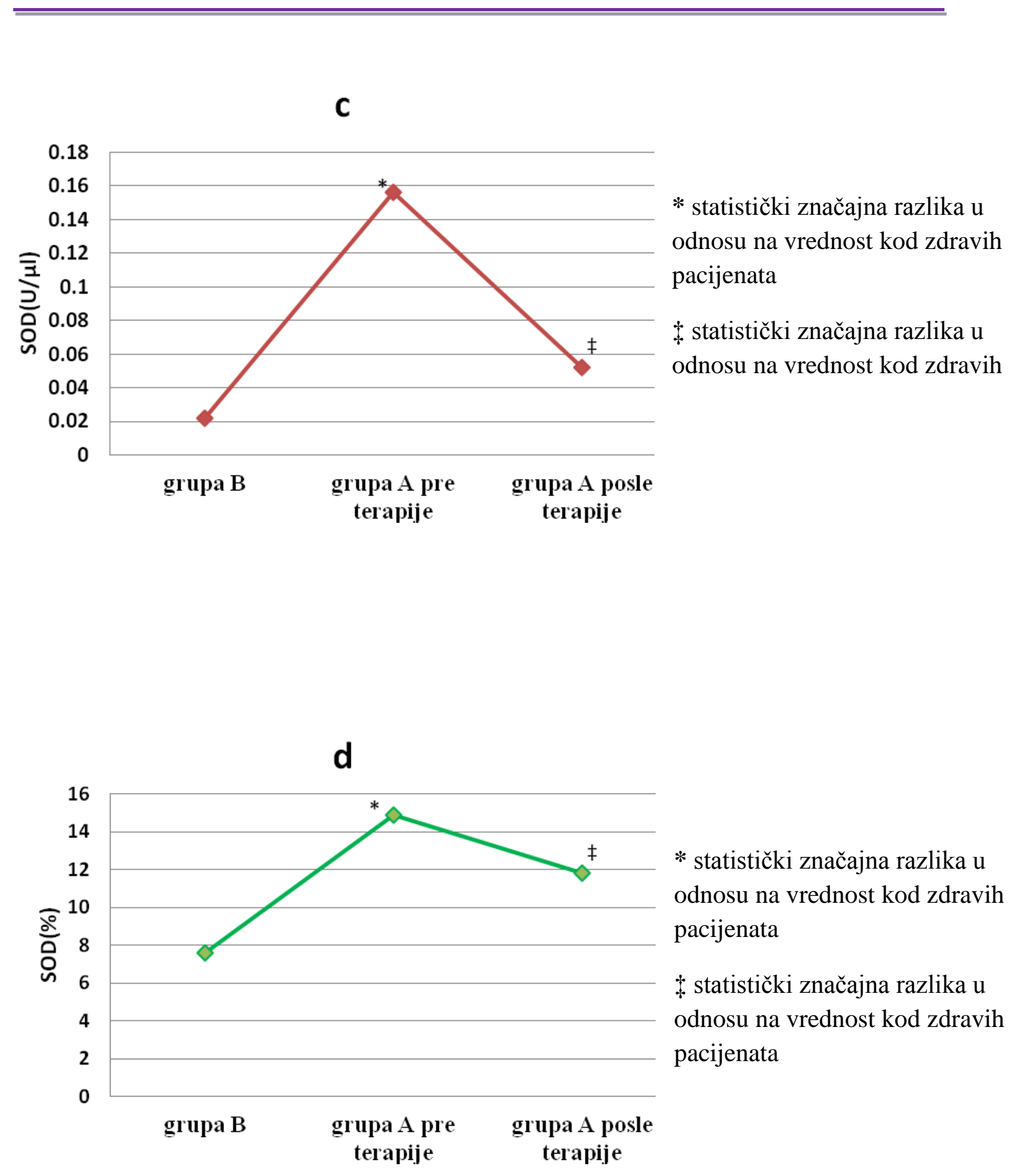


\subsubsection{MARKERI OKSIDATIVNOG STRESA U KRVI}

\subsubsection{Markeri oksidativnog stresa u krvi kod pacijenata sa parodontopatijom pre terapije}

Srednja vrednost 8-OHdG u krvi pacijenata sa parodontopatijom na početku istraživanja iznosila je 0,472 ng/ml, sa opsegom vrednosti od 0,262 ng/ml do 0,812 ng/ml. Vrednosti MDA kretale su se u intervalu od $0,290 \mathrm{pmol} / \mu \mathrm{l}$ do $0,700 \mathrm{pmol} / \mu \mathrm{l}$ dok je srednja vrednost ovog markera iznosila $0,497 \mathrm{pmol} / \mu \mathrm{l}$. Srednja vrednost SOD pre

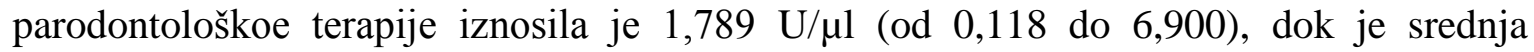
vrednosti aktivnosti ovog markera bila 47,821\% (od 28,790 do 80,090) (Tabela 15).

Tabela 15. Markeri oksidativnog stresa u krvi kod pacijenata sa parodontopatijom pre terapije

\begin{tabular}{llllll}
\hline & $\bar{X}$ & SD & SG & Minimum & Maksimum \\
\hline $\begin{array}{l}\text { 8-OHdG } \\
(\mathbf{n g} / \mathbf{m l})\end{array}$ & 0,472 & 0,176 & 0,032 & 0,262 & 0,812 \\
\hline MDA & 0,497 & 0,134 & 0,024 & 0,290 & 0,700 \\
$(\mathbf{p m o l} / \boldsymbol{\mu l})$ & & & & & \\
\hline SOD & 1,789 & 1,773 & 0,324 & 0,118 & 6,900 \\
$(\mathbf{U} / \boldsymbol{\mu l})$ & & & & & 80,090 \\
\hline SOD $(\%)$ & 47,821 & 12,631 & 2,305 & 28,790 & \\
\hline
\end{tabular}


5.2.2.2. Markeri oksidativnog stresa u krvi kod pacijenata sa zdravim parodoncijumom

Srednja vrednost 8-OHdG u krvi pacijenata sa zdravim parodoncijumom iznosila je 0,449 ng/ml, sa opsegom vrednosti od 0,113 ng/ml do 1,000 ng/ml. Vrednosti MDA kretale su se u intervalu od $0,129 \mathrm{pmol} / \mu 1$ do $0,620 \mathrm{pmol} / \mu 1$ dok je srednja vrednost ovog markera iznosila $0,398 \mathrm{pmol} / \mu \mathrm{l}$. Srednja vrednost SOD iznosila je 1,773 U/ $\mu \mathrm{l}$ (od 0,852 do 7,000), dok je vrednost aktivnosti ovog markera bila 45,05\% (od 40,221 do 81,121) (Tabela 16).

Tabela 16. Markeri oksidativnog stresa u krvi kod pacijenata sa zdravim parodoncijumom

\begin{tabular}{lccccc}
\hline & $\bar{X}$ & SD & SG & Minimum & Maksimum \\
\hline $\begin{array}{l}\text { 8-OHdG } \\
(\mathbf{n g} / \mathbf{m l})\end{array}$ & 0,449 & 0,222 & 0,049 & 0,113 & 1,000 \\
\hline $\begin{array}{l}\text { MDA } \\
(\mathbf{p m o l} / \boldsymbol{\mu l})\end{array}$ & 0,398 & 0,129 & 0,029 & 0,129 & 0,620 \\
\hline $\begin{array}{l}\text { SOD } \\
(\mathbf{U} / \boldsymbol{\mu l})\end{array}$ & 1,773 & 1,490 & 0,333 & 0,852 & 7,000 \\
\hline SOD $(\%)$ & 45,050 & 12,621 & 2,822 & 40,221 & 81,121 \\
\hline
\end{tabular}


5.2.2.3. Analiza razlike markera oksidativnog stresa u krvi kod pacijenata sa parodontopatijom pre terapije i zdravih pacijenata

Analizom dobijenih podataka može se konstatovati da su pacijenti sa parodontopatijom na početku istraživanja imali više srednje vrednosti svih ispitivanih

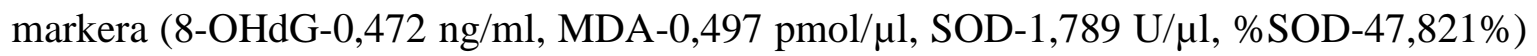
u krvi u odnosu na zdrave ispitanike (8-OHdG-0,449 ng/ml, MDA-0,398 pmol/ $\mu$ l, SOD$1,774 \mathrm{U} / \mu 1, \% \mathrm{SOD}-45,05 \%$ ), međutim samo je razlika u vrednostima MDA među posmatranim grupama bila statistički značajna $(\mathrm{p}=0,013)$ (Tabela 17, Grafikon 5).

Tabela 17. Značajnost razlike markera oksidativnog stresa u krvi kod pacijenata sa parodontopatijom (grupa A) pre terapije i zdravih pacijenata (grupa B)

\begin{tabular}{lclll}
\hline & \multicolumn{1}{c}{ Grupa A } & Grupa B & t & $\mathbf{p}$ \\
& $(\bar{X} \pm \mathbf{S D})$ & $(\bar{X} \pm \mathbf{S D})$ & & \\
\hline $\begin{array}{l}\text { 8-OHdG } \\
(\mathbf{n g} / \mathbf{m l})\end{array}$ & $0,472 \pm 0,176$ & $0,449 \pm 0,222$ & 0,411 & 0,683 \\
\hline MDA & $0,497 \pm 0,134$ & $0,398 \pm 0,129$ & 2,593 & $\mathbf{0 , 0 1 3}$ \\
$(\mathbf{p m o l} / \boldsymbol{\mu l})$ & & & & \\
\hline SOD & $1,789 \pm 1,773$ & $1,774 \pm 1,490$ & 0,031 & 0,975 \\
$(\mathbf{U} / \boldsymbol{\mu l})$ & & & 0,532 & 0,539 \\
\hline SOD $(\%)$ & $47,821 \pm 12,627$ & $45,050 \pm 12,620$ & & \\
\hline
\end{tabular}


5.2.2.4. Markeri oksidativnog stresa u krvi kod pacijenata sa parodontopatijom posle terapije

Posle terapije, srednja vrednost $8-\mathrm{OHdG}$ u krvi pacijenata sa parodontopatijom iznosila je 0,449 ng/ml, MDA 0,467 pmol/ $\mu \mathrm{l}$, dok su srednje vrednosti SOD i \%SOD bile $1,772 \mathrm{U} / \mu \mathrm{l}$ i $47,061 \%$ (Tabela 18).

Tabela 18. Markeri oksidativnog stresa u krvi pacijenata sa parodontopatijom posle terapije

\begin{tabular}{lccccc}
\hline & $\bar{X}$ & SD & SG & Minimum & Maksimum \\
\hline $\begin{array}{l}\text { 8-OHdG } \\
(\mathbf{n g} / \mathbf{m l})\end{array}$ & 0,449 & 0,176 & 0,032 & 0,165 & 0,775 \\
\hline $\begin{array}{l}\text { MDA } \\
(\mathbf{p m o l} / \boldsymbol{\mu l})\end{array}$ & 0,467 & 0,113 & 0,021 & 0,290 & 0,700 \\
\hline SOD & 1,772 & 1,326 & 0,242 & 0,226 & 6,300 \\
$(\mathbf{U} / \boldsymbol{\mu l})$ & & & & & 83,091 \\
\hline SOD $(\%)$ & 47,061 & 9,605 & 1,754 & 33,281 & 83,000 \\
\hline
\end{tabular}


5.2.2.5. Analiza razlike markera oksidativnog stresa u krvi kod pacijenata sa parodontopatijom pre i posle terapije

Dobijeni rezultati pokazuju da je nakon terapije $\mathrm{u}$ krvi pacijenata sa parodontopatijom zabeležen pad srednjih vrednosti svih ispitivanih markera oksidativnog stresa. Tako je srednja vrednost $8-\mathrm{OHdG}$ smanjena za 0,023 ng/ml, dok je srednja vrednost MDA smanjena za 0,032 pmol/ $\mu 1$. Srednja vrednost SOD posle terapije smanjena je za 0,017 U/ $\mu 1$, dok je vrednost aktivnosti ovog markera smanjena za 0,761\%. Ni jedno smanjenje, međutim, nije bilo statistički značajno (Tabela 19, Grafikon 5).

Tabela 19. Značajnost razlike markera oksidativnog stresa u krvi kod pacijenata sa parodontopatijom pre i posle terapije

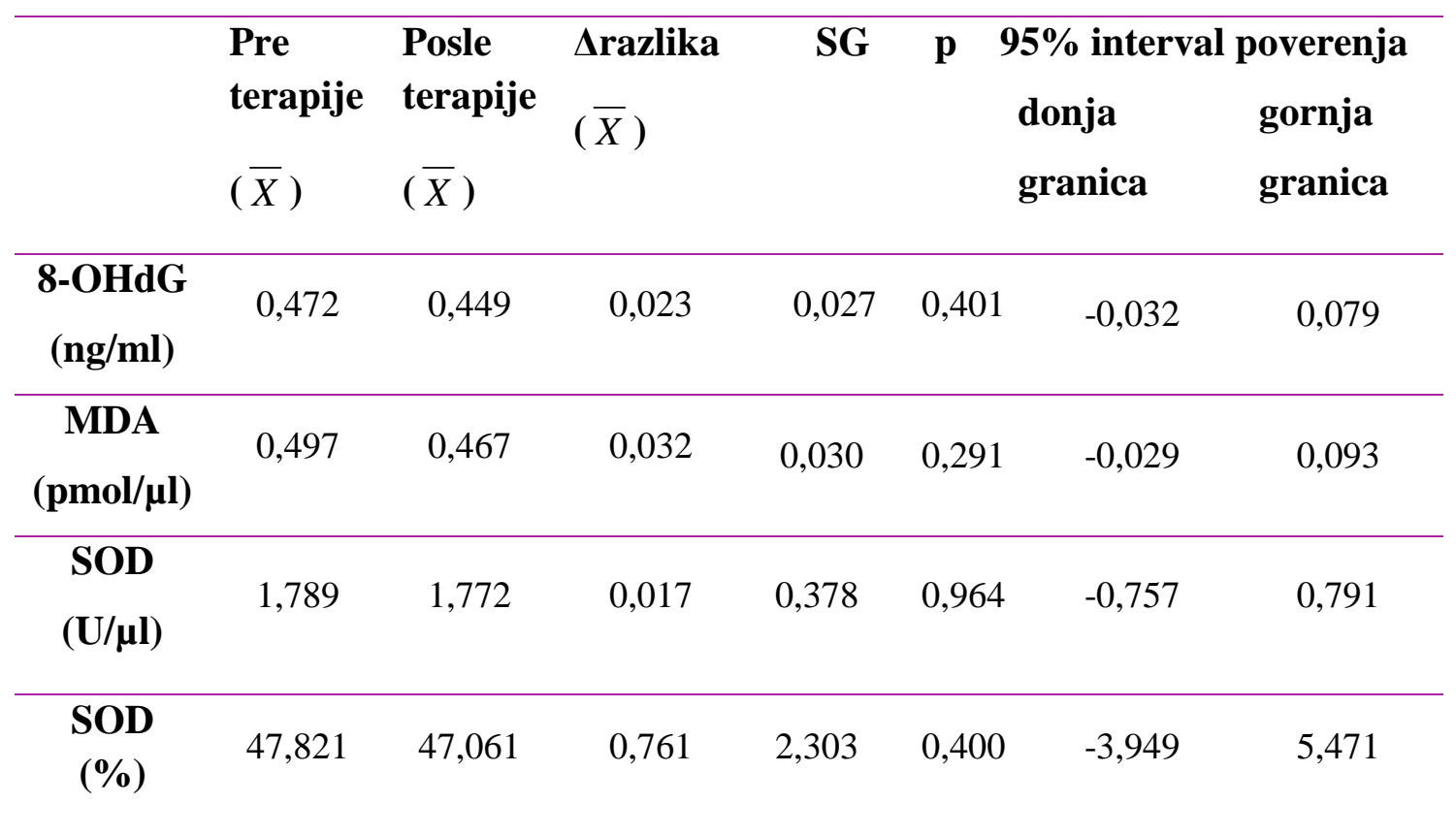




\subsubsection{Analiza razlike markera oksidativnog stresa u krvi kod pacijenata sa parodontopatijom posle terapije i zdravih pacijenata}

Poređenjem vrednosti markera oksidativnog stresa $u$ krvi pacijenata sa parodontopatijom posle terapije sa vrednostima ovih markera kod zdravih pacijenata, može se konstatovati da je kauzalna terapija parodontopatije dovela do smanjenja vrednosti 8-OHdG i SOD do nivoa ovih markera kod zdravih pacijenata. Isto tako, srednja vrednost aktivnosti SOD nakon terapije u grupi pacijenata sa parodontopatijom $(47,061 \%)$ smanjena je gotovo do nivoa vrednosti kod zdravih pacijenata $(45,050 \%)$. Iako smanjena nakon terapije, srednja vrednost MDA u grupi pacijenata sa parodontopatijom bila je $\mathrm{i}$ dalje znatno viša od srednje vrednosti ovog markera kod pacijenata sa zdravim parodoncijumom ( $\mathrm{p}=0,059)$ (Tabela 20, Grafikon 5).

Tabela 20. Značajnost razlike markera oksidativnog stresa u krvi kod pacijenata sa parodontopatijom (grupa A) posle terapije i zdravih pacijenata (grupa B)

\begin{tabular}{lclll}
\hline & Grupa A & Grupa B & \\
& $(\bar{X} \pm$ SD $)$ & $(\bar{X} \pm$ SD $)$ & & \\
\hline $\mathbf{8 - O H d G}$ & & & \\
$(\mathbf{n g} / \mathbf{m l})$ & $0,449 \pm 0,176$ & $0,449 \pm 0,222$ & 0,000 & 1,000 \\
\hline MDA & & & & \\
$(\mathbf{p m o l} / \boldsymbol{\mu l})$ & $0,467 \pm 0,113$ & $0,398 \pm 0,129$ & 1,931 & 0,059 \\
\hline SOD & & & & \\
$(\mathbf{U} / \boldsymbol{\mu l})$ & $1,772 \pm 1,326$ & $1,774 \pm 1,490$ & $-0,005$ & 0,996 \\
\hline SOD $(\%)$ & & & 0,525 \\
\hline
\end{tabular}


Grafikon 5. Markeri oksidativnog stresa u krvi kod pacijenata sa parodontopatijom (grupa A) pre i posle terapije i zdravih pacijenata (grupa B); (a) 8-OHdG, (b) MDA, (c) SOD $i(d) \% S O D$

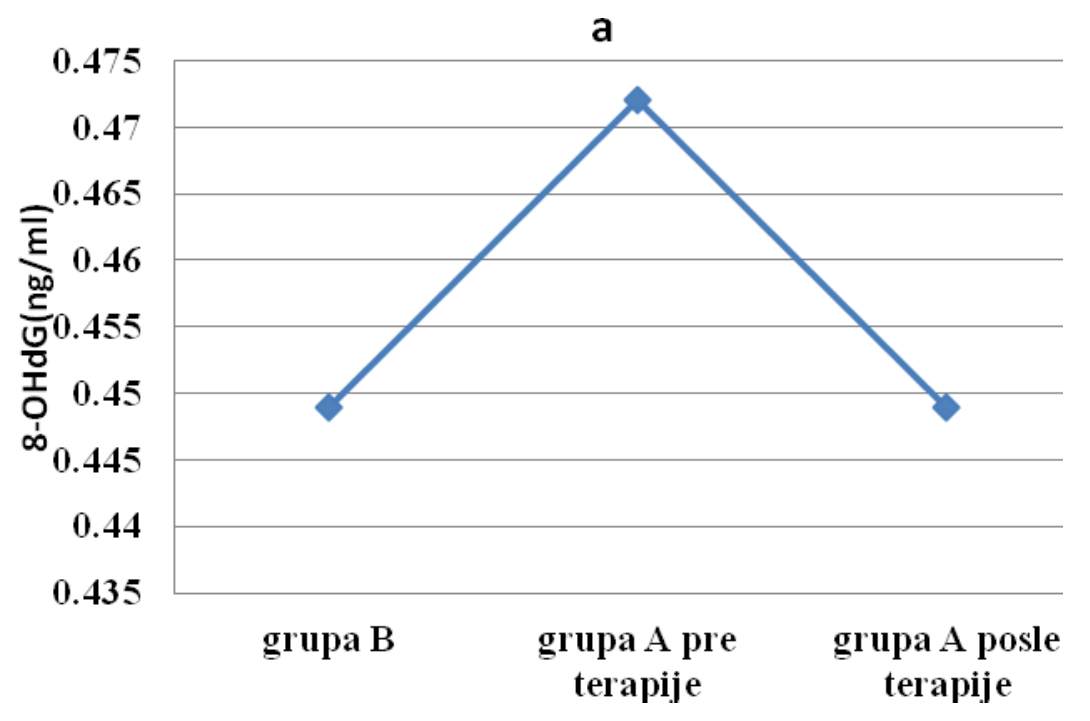

b

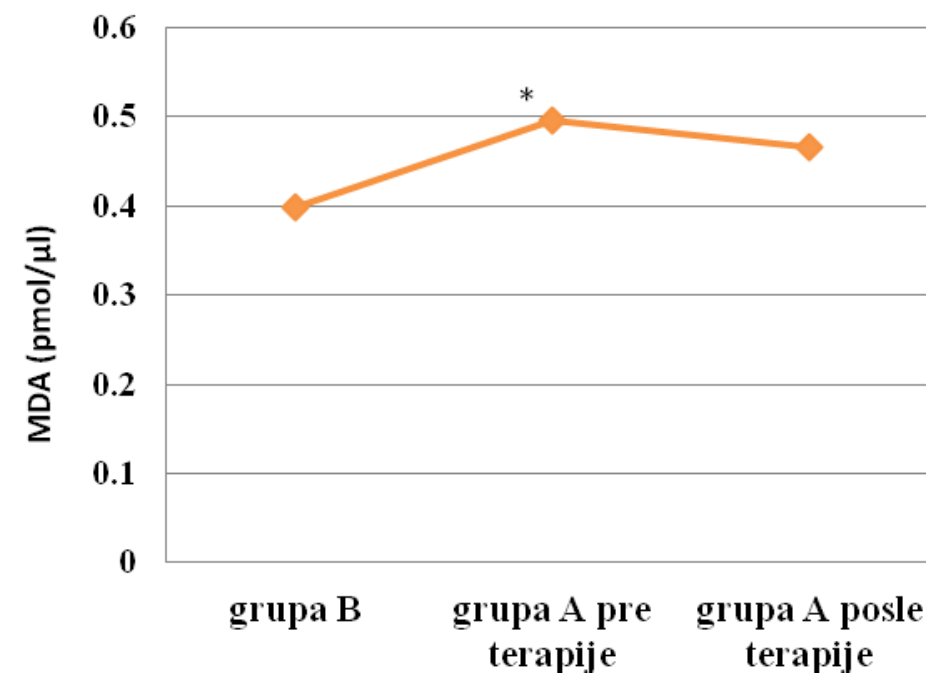

* statistički značajna razlika u odnosu na vrednost kod zdravih pacijenata 
C
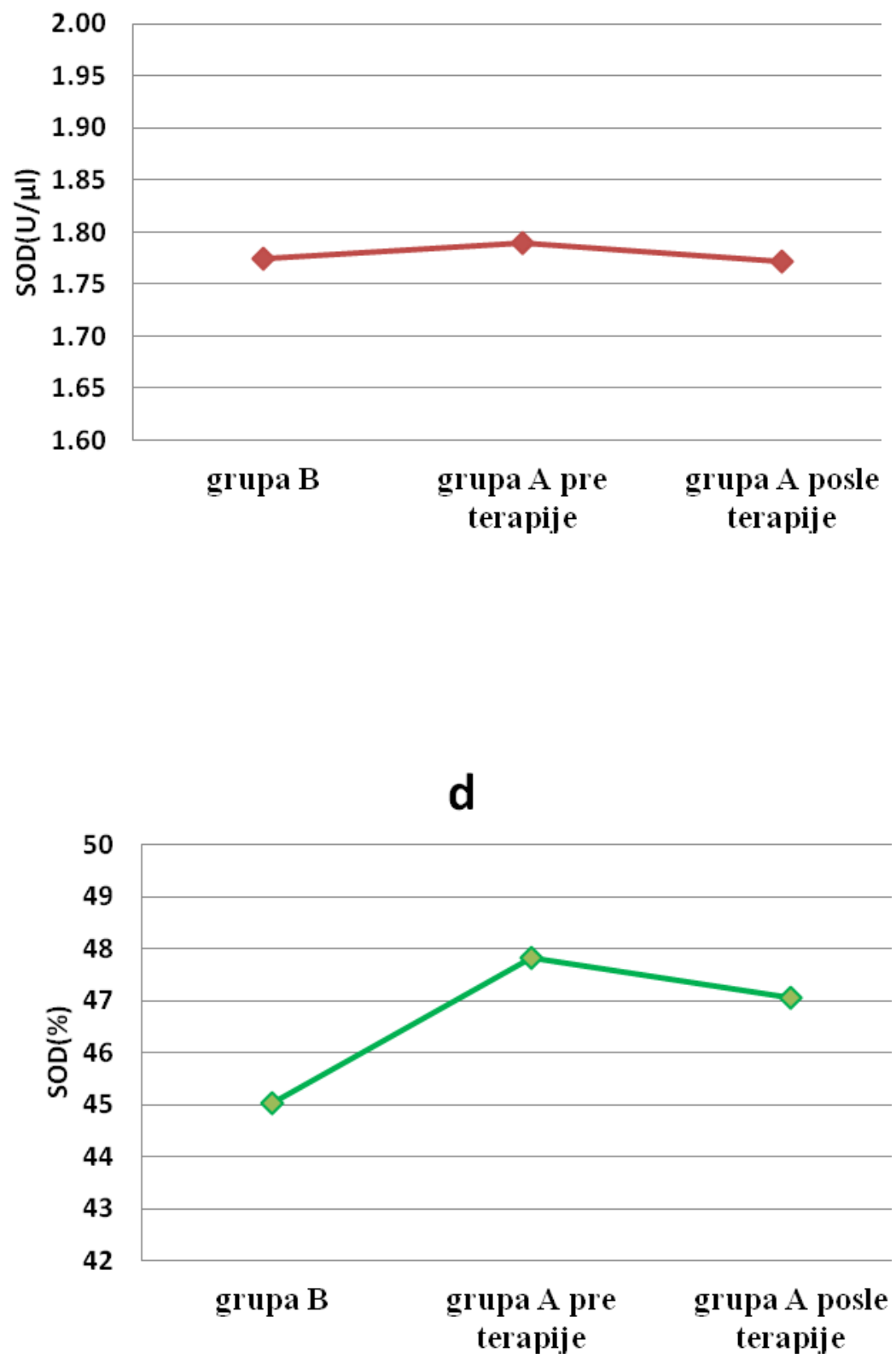


\section{2. 3. KORELACIJE MARKERA OKSIDATIVNOG STRESA IZ PLJUVAČKE I} KRVI

Da bismo utvrdili povezanost markera oksidativnog stresa iz pljuvačke i krvi koristili smo Spearmanov koeficijent korelacije. Dobijeni rezultati pokazuju da je pre terapije zabeležena statistički značajna pozitivna korelacija između MDA u pljuvački i krvi pacijenata sa parodontopatijom $(\mathrm{p}=0,012)$ (Grafikon 6). Korelacije 8-OHdG i SOD su takođe bile pozitivne, ali nisu dostigle statistički značajan nivo (Tabela 21).

Tabela 21. Korelacija markera oksidativnog stresa u pljuvački i krvi kod pacijenata sa parodontopatijom pre terapije

\begin{tabular}{l|c|c}
\hline & $\mathrm{r}$ & $\mathrm{p}$ \\
\hline 8-OHdG-p 8-OHdG-k & 0,186 & 0,324 \\
\hline MDA-p MDA-k & 0,451 & $\mathbf{0 , 0 1 2}$ \\
\hline SOD-p SOD-k & 0,212 & 0,235 \\
\hline
\end{tabular}

p-pljuvačka, k- krv

Grafikon 6. Korelacija MDA iz pljuvačke i krvi pre terapije

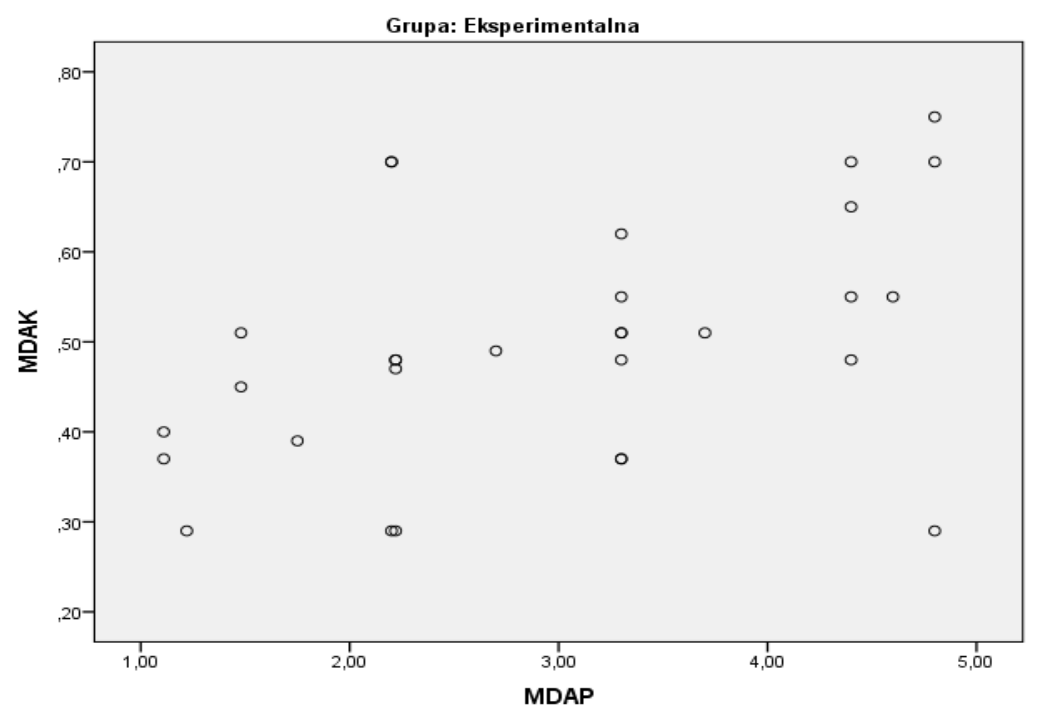


Posle terapije, zabeležena je pozitivna korelacija za MDA ( $r=0,165)$, dok su SOD i 8-OHdG pokazivali negativnu korelaciju (SOD r=-0,219, 8-OHdG r=-0,060), međutim ni jedna korelacija nije bila na statistički značajnom nivou (Tabela 22).

Tabela 22. Korelacija markera oksidativnog stresa u pljuvački i krvi kod pacijenata sa parodontopatijom posle terapije

\begin{tabular}{l|c|c}
\hline & $\mathrm{r}$ & $\mathrm{p}$ \\
\hline 8-OHdG-p 8-OHdG-k & $-0,060$ & 0,751 \\
\hline MDA-p MDA-k & 0,165 & 0,383 \\
\hline SOD-p SOD-k & $-0,219$ & 0,246 \\
\hline
\end{tabular}

p-pljuvačka, k- krv

U grupi pacijenata sa zdravim parodoncijumom zabeležene su pozitivne korelacije za 8-OHdG, za MDA i za SOD u pljuvački i krvi, međutim ni jedna korelacija nije bila na statistički značajnom nivou (8-OHdG p=0,195, MDA p=0,240, SOD p=0,249) (Tabela 23).

Tabela 23. Korelacija markera oksidativnog stresa u pljuvački i krvi kod pacijenata sa zdravim parodoncijumom

\begin{tabular}{l|c|c}
\hline & $\mathrm{r}$ & $\mathrm{p}$ \\
\hline 8-OHdG-p 8-OHdG-k & 0,303 & 0,195 \\
\hline MDA-p MDA-k & 0,275 & 0,240 \\
\hline SOD-p SOD-k & 0,270 & 0,249 \\
\hline
\end{tabular}

p-pljuvačka, k- krv 


\subsection{MARKERI OKSIDATIVNOG STRESA KOD PACIJENATA SA PARODONTOPATIJOM U ZAVISNOSTI OD PARODONTOLOŠKOG STATUSA}

U cilju utvrđivanja uticaja pojedinih parametara stanja parodoncijuma na povećanje oksidativnog stresa, posebno su analizirani markeri oksidativnog stresa u pljuvački i krvi u zavisnosti od stepena inflamacije gingive, dubine sondiranja i nivoa pripojnog epitela.

U odnosu na stepen inflamacije gingive pacijenti sa parodontopatijom su podeljeni na grupu sa umerenom inflamacijom (Loë-Silness 0,1-2) i na grupu sa izraženom inflamacijom (Loë-Silness 2,1-3) Grafikon 7.

Grafikon 7. Kategorizacija pacijenata prema stepenu inflamacije gingive (GI)

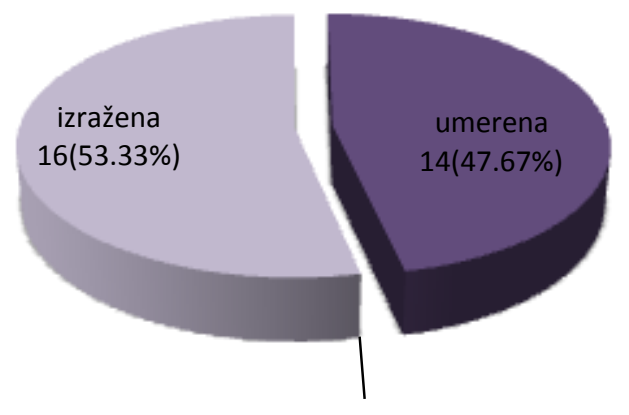

U odnosu na dubinu sondiranja (DS) pacijenti sa parodontopatijom su podeljeni na grupu sa $\mathrm{DS} \geq 5 \mathrm{~mm}$ na više od $20 \%$ površina zuba i na grupu sa $\mathrm{DS} \geq 5 \mathrm{~mm}$ na manje od $20 \%$ površina zuba (Grafikon 8 ). 
Grafikon 8. Kategorizacija pacijenata prema dubini sondiranja

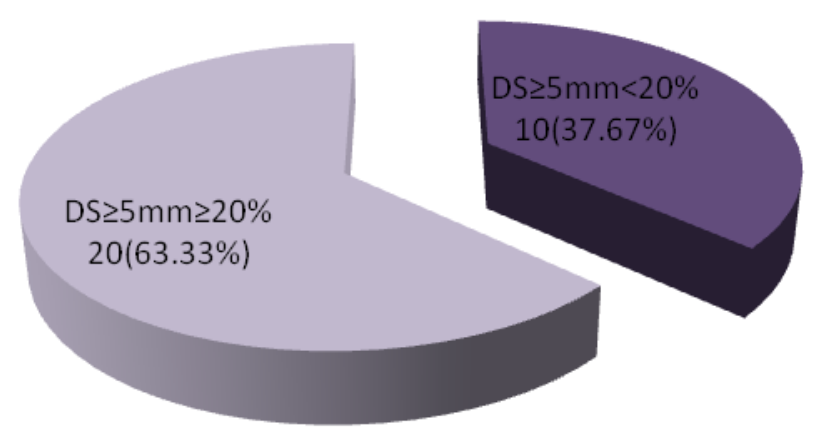

U odnosu na nivo pripojnog epitela (NPE) pacijenti sa parodontopatijom su podeljeni na grupu sa NPE $\geq 3 \mathrm{~mm}$ i na grupu sa NPE $<3 \mathrm{~mm}$ (Grafikon 9).

Grafikon 9. Kategorizacija pacijenata prema nivou pripojnog epitela
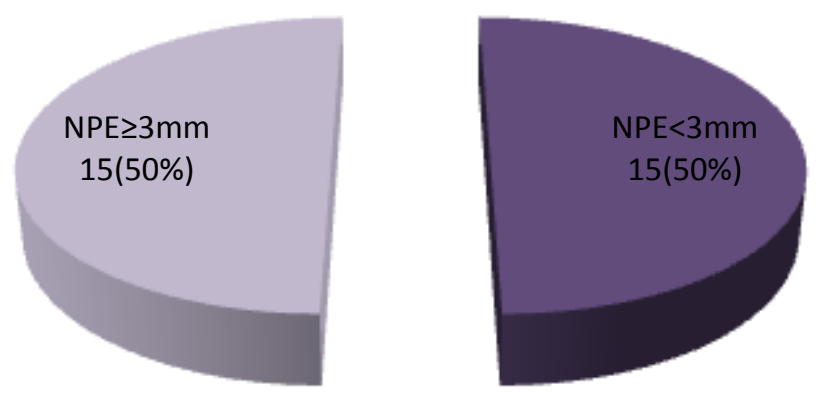


\subsubsection{MARKERI OKSIDATIVNOG STRESA U PLJUVAČKI KOD PACIJENATA SA PARODONTOPATIJOM U ZAVISNOSTI OD PARODONTOLOŠKOG STATUSA}

\subsubsection{MARKERI OKSIDATIVNOG STRESA U PLJUVAČKI KOD PACIJENATA} SA PARODONTOPATIJOM U ZAVISNOSTI OD STEPENA INFLAMACIJE GINGIVE

\subsection{Markeri oksidativnog stresa u pljuvački kod pacijenata sa parodontopatijom u zavisnosti od stepena inflamacije gingive pre terapije}

Kod pacijenata sa izraženom inflamacijom gingive na početku istraživanja zabeležene su više srednje vrednosti svih ispitivanih markera oksidativnog stresa u odnosu na pacijente sa umerenom inflamacijom. Tako je srednja vrednost MDA $(3,616 \mathrm{pmol} / \mu \mathrm{l}) \mathrm{u}$ grupi pacijenata sa izraženom inflamacijom statistički značajno viša $(p=0,045)$ u odnosu na vrednost $(2,419 \mathrm{pmol} / \mu \mathrm{l}) \mathrm{u}$ grupi pacijenata sa umerenom inflamacijom gingive. Isto tako i vrednosti SOD i njegove aktivnosti više su kod pacijenata sa izraženom inflamacijom $(0,297 \mathrm{U} / \mu 1,18,271 \%)$ nego kod pacijeata sa umerenom inflamacijom $(0,033 \mathrm{U} / \mu \mathrm{l}, 11,930 \%)$ što je blizu statističke značajnosti $(\mathrm{p}=0,063, \mathrm{p}=0,065)$ (Tabela 24$)$. 
Tabela 24. Značajnost razlike markera oksidativnog stresa u pljuvački kod pacijenata sa parodontopatijom u zavisnosti od stepena inflamacije gingive pre terapije

\begin{tabular}{ccccccc}
\hline & Forma & $\bar{X}$ & SD & Minimum & Maksimum & $\mathrm{p}$ \\
& inflamacije & & & & & \\
\hline $\begin{array}{c}\text { 8-OHdG } \\
(\mathrm{ng} / \mathrm{ml})\end{array}$ & Umerena & 0,852 & 0,566 & 0,388 & 2,080 & 0,839 \\
& Izražena & 0,889 & 0,418 & 0,388 & 2,100 & \\
\hline $\begin{array}{c}\text { MDA } \\
(\mathrm{pmol} / \mu \mathrm{l})\end{array}$ & Umerena & 2,419 & 1,101 & 1,110 & 4,400 & $\mathbf{0 , 0 4 5}$ \\
& Izražena & 3,616 & 1,216 & 1,480 & 4,800 & \\
\hline SOD $(\mathrm{U} / \mu \mathrm{l})$ & Umerena & 0,033 & 0,012 & 0,012 & 0,046 & 0,063 \\
& Izražena & 0,297 & 0.548 & 0,016 & 1,900 & \\
\hline SOD\% & Umerena & 11,930 & 4,961 & 2,000 & 17,871 & \multirow{2}{*}{0,065} \\
& Izražena & 18,271 & 12,081 & 6,710 & 39,930 & \\
\hline
\end{tabular}

\subsection{Markeri oksidativnog stresa u pljuvački kod pacijenata sa parodontopatijom u zavisnosti od stepena inflamacije gingive posle terapije}

Posle sprovedene parodontološke terapije, vrednosti markera oksidativnog stresa kod pacijenata sa izraženom formom inflamacije su i dalje više nego kod pacijenata sa umerenom formom inflamacije, ali te razlike nisu bile na statistički značajnom novou. Tako je srednja vrednost 8-OHdG kod pacijenata sa izraženom formom inflamacije posle terapije iznosila $0,665 \mathrm{ng} / \mathrm{ml}$ dok je vrednost ovog markera u pljuvački pacijenata sa umerenom formom inflamacije gingive bila $0,576 \mathrm{ng} / \mathrm{ml}$. Srednje vrednosti ostalih markera kod pacijenata sa izraženom inflamacijom su iznosile MDA-2,495 pmol/ $\mu 1$, SOD0,075 U/ $\mu 1$, \%SOD-13,041, dok su vrednosti kod pacijenata sa umerenom inflamacijom

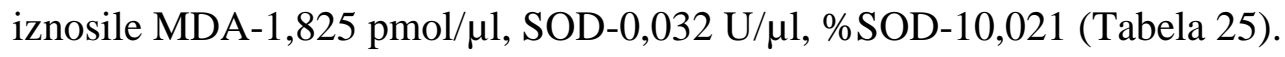


Tabela 25. Značajnost razlike markera oksidativnog stresa u pljuvački kod pacijenata sa parodontopatijom u zavisnosti od stepena inflamacije gingive posle terapije

\begin{tabular}{|c|c|c|c|c|c|c|}
\hline Marker & $\begin{array}{c}\text { Forma } \\
\text { inflamacije }\end{array}$ & $\bar{X}$ & SD & Minimum & Maksimum & $\mathrm{p}$ \\
\hline \multirow{2}{*}{$\begin{array}{c}\text { 8-OHdG } \\
(\mathrm{ng} / \mathrm{ml})\end{array}$} & Umerena & 0,576 & 0,409 & 0,246 & 1,625 & \multirow{2}{*}{0,529} \\
\hline & Izražena & 0,665 & 0,352 & 0,246 & 1,180 & \\
\hline \multirow{2}{*}{$\begin{array}{c}\text { MDA } \\
(\mathrm{pmol} / \mu \mathrm{l})\end{array}$} & Umerena & 1,825 & 0,728 & 1,110 & 3,300 & \multirow{2}{*}{0,052} \\
\hline & Izražena & 2,495 & 1,069 & 1,110 & 4,800 & \\
\hline \multirow{2}{*}{ SOD $(U / \mu 1)$} & Umerena & 0,032 & 0,019 & 0,016 & 0,062 & \multirow{2}{*}{0,110} \\
\hline & Izražena & 0,075 & 0,058 & 0,016 & 0,138 & \\
\hline \multirow{2}{*}{ SOD\% } & Umerena & 10,021 & 3,950 & 4,130 & 17,210 & \multirow{2}{*}{0,637} \\
\hline & Izražena & 13,041 & 7,701 & 4,130 & 26,590 & \\
\hline
\end{tabular}

\subsection{Analiza razlike markera oksidativnog stresa u pljuvački kod pacijenata sa} parodontopatijom u zavisnosti od stepena inflamacije gingive pre i posle terapije

Analizom dobijenih podataka može se konstatovati da je parodontolološka terapija dovela do statistički značajnog smanjenja srednjih vrednosti 8-OHdG i MDA kako u grupi pacijenata sa izraženom tako i u grupi sa umerenom formom inflamacije. Srednja vrednost SOD i njegove aktivnosti su značajno smanjene kod pacijenata sa izraženom formom inflamacije gingive, dok to smanjenje kod pacijenata sa umerenom inflamacijom nije bilo statistički značajno. Razlika u promeni srednjih vrednosti ispitivanih markera među grupama pre i posle terapije nije bila statistički značajna (Tabela 26). 
Tabela 26. Analiza razlike markera oksidativnog stresa u pljuvački kod pacijenata sa umerenom i izraženom inflamacijom gingive pre i posle terapije

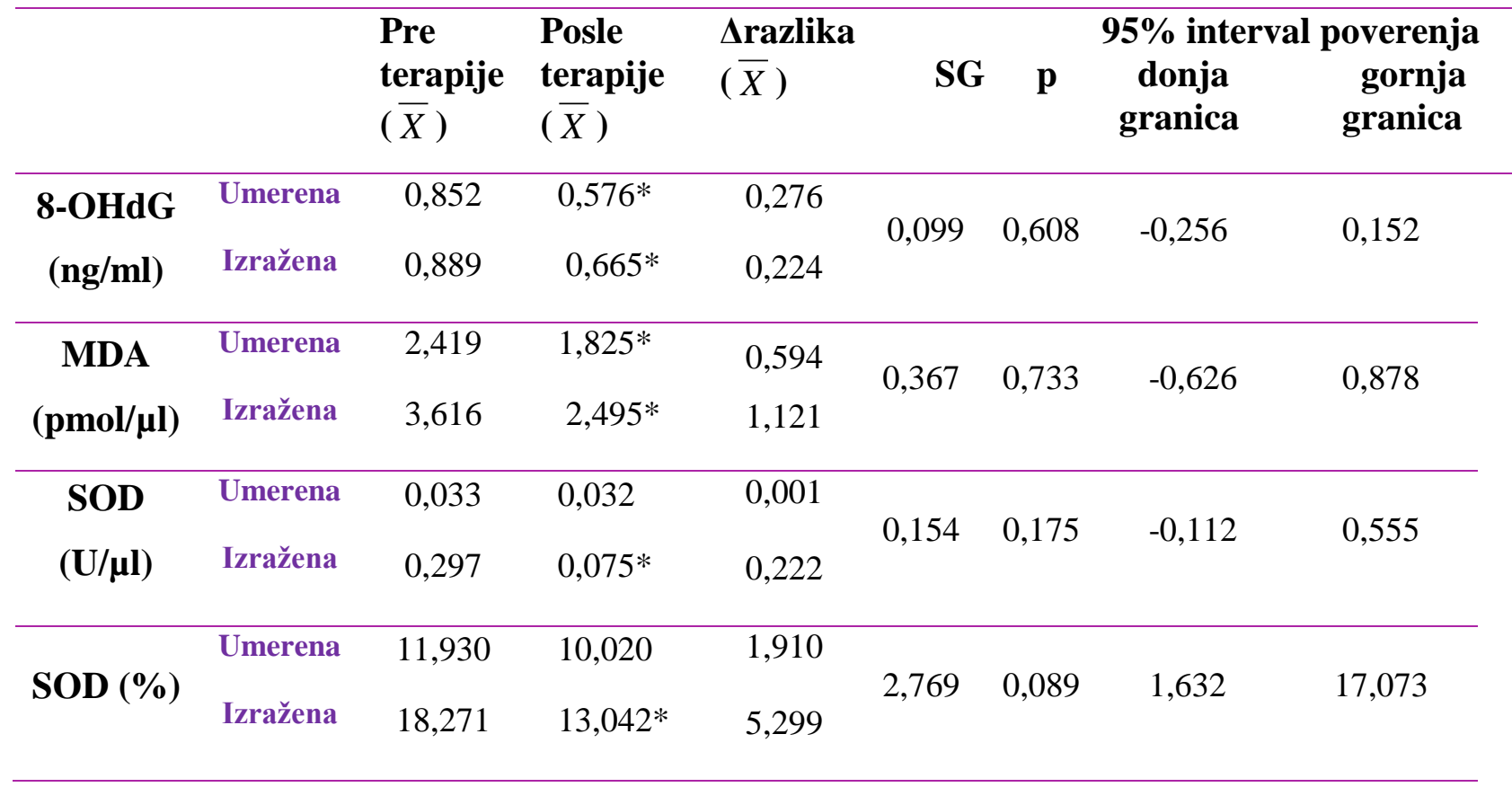

*statistički značajna razlika u odnosu na vrednosti pre terapije

\subsubsection{MARKERI OKSIDATIVNOG STRESA U PLJUVAČKI KOD PACIJENATA SA PARODONTOPATIJOM U ZAVISNOSTI OD DUBINE SONDIRANJA}

\subsection{Markeri oksidativnog stresa u pljuvački kod pacijenata sa parodontopatijom u zavisnosti od dubine sondiranja pre terapije}

Vrednosti markera oksidativnog stresa kod pacijenata sa većom dubinom sondiranja bile su više u odnosu na pacijente sa manjom dubinom sondiranja na početku istraživanja. Srednja vrednost 8 -OhdG u grupi pacijenata sa $\mathrm{DS} \geq 5 \mathrm{~mm}>20 \%$ iznosila je $0,967 \mathrm{ng} / \mathrm{ml}$, a u grupi pacijenata sa $\mathrm{DS} \geq 5 \mathrm{~mm}<20 \% 0,700 \mathrm{ng} / \mathrm{ml}$, što je blizu statističke značajnosti $(\mathrm{p}=0,057)$. Srednje vrednosti ostalih markera kod pacijenata sa većom 
dubinom sondiranja iako više, nisu se statistički značajno razlikovale od vrednosti kod pacijenata sa manjom dubinom sondiranja (Tabela 27).

Tabela 27. Značajnost razlike markera oksidativnog stresa u pljuvački kod pacijenata sa parodontopatijom u zavisnosti od dubine sondiranja pre terapije

\begin{tabular}{|c|c|c|c|c|c|c|}
\hline & $\mathrm{DS}$ & $\bar{X}$ & $\mathrm{SD}$ & Minimum & Maksimum & $\mathrm{p}$ \\
\hline \multirow{2}{*}{$\begin{array}{c}\text { 8-OHdG } \\
(\mathrm{ng} / \mathrm{ml})\end{array}$} & $\geq 5 \mathrm{~mm}<20 \%$ & 0,700 & 0,537 & 0,388 & 2,080 & \multirow{2}{*}{0,057} \\
\hline & $\geq 5 \mathrm{~mm} \geq 20 \%$ & 0,967 & 0,453 & 0,406 & 2,100 & \\
\hline \multirow{2}{*}{$\begin{array}{c}\text { MDA } \\
(\mathrm{pmol} / \mu \mathrm{l})\end{array}$} & $\geq 5 \mathrm{~mm}<20 \%$ & 2,619 & 1,110 & 1,110 & 4,400 & \multirow{2}{*}{0,203} \\
\hline & $\geq 5 \mathrm{~mm} \geq 20 \%$ & 3,207 & 1,234 & 1,110 & 4,800 & \\
\hline \multirow{2}{*}{ SOD $(U / \mu 1)$} & $\geq 5 \mathrm{~mm}<20 \%$ & 0,035 & 0,011 & 0,016 & 0,046 & \multirow{2}{*}{0,099} \\
\hline & $\geq 5 \mathrm{~mm} \geq 20 \%$ & 0,227 & 0,481 & 0,012 & 1,900 & \\
\hline \multirow{2}{*}{ SOD\% } & $\geq 5 \mathrm{~mm}<20 \%$ & 10,081 & 4,386 & 5,341 & 17,670 & \multirow{2}{*}{0,277} \\
\hline & $\geq 5 \mathrm{~mm} \geq 20 \%$ & 16,050 & 11,350 & 2,000 & 30,000 & \\
\hline
\end{tabular}

\subsection{Markeri oksidativnog stresa u pljuvački kod pacijenata sa parodontopatijom u zavisnosti od dubine sondiranja posle terapije}

Dobijeni rezultati pokazuju da su posle sprovedene parodontološke terapije srednja vrednosti markera oksidativnog stresa kod pacijenata sa većom dubinom sondiranja (8-

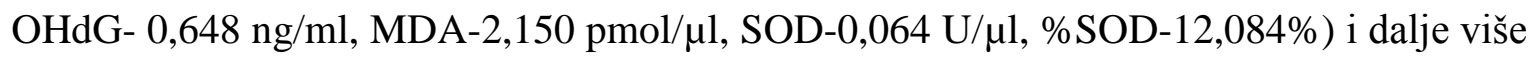
nego kod pacijenata sa manjom dubinom sondiranja (8-OHdG-0,565 ng/ml, MDA-2,087

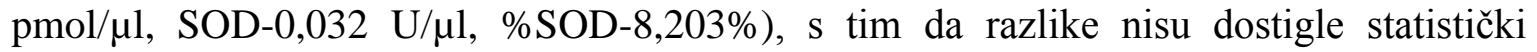
značajan nivo (Tabela 28). 
Tabela 28. Značajnost razlike markera oksidativnog stresa u pljuvački kod pacijenata sa parodontopatijom u zavisnosti od dubine sondiranja posle terapije

\begin{tabular}{|c|c|c|c|c|c|c|}
\hline & $\mathrm{DS}$ & $\bar{X}$ & SD & Minimum & Maksimum & $\mathrm{p}$ \\
\hline \multirow{2}{*}{$\begin{array}{c}\text { 8-OHdG } \\
(\mathrm{ng} / \mathrm{ml})\end{array}$} & $\geq 5 \mathrm{~mm}<20 \%$ & 0,565 & 0,396 & 0,388 & 2,080 & \multirow{2}{*}{0,570} \\
\hline & $\geq 5 \mathrm{~mm} \geq 20 \%$ & 0,648 & 0,377 & 0,406 & 2,100 & \\
\hline \multirow{2}{*}{$\begin{array}{c}\text { MDA } \\
(\mathrm{pmol} / \mu \mathrm{l})\end{array}$} & $\geq 5 \mathrm{~mm}<20 \%$ & 2,087 & 0,882 & 1,110 & 3,300 & \multirow{2}{*}{0,867} \\
\hline & $\geq 5 \mathrm{~mm} \geq 20 \%$ & 2,150 & 1,025 & 1,110 & 4,800 & \\
\hline \multirow{2}{*}{ SOD $(U / \mu l)$} & $\geq 5 \mathrm{~mm}<20 \%$ & 0,032 & 0,036 & 0,016 & 0,138 & \multirow{2}{*}{0,070} \\
\hline & $\geq 5 \mathrm{~mm} \geq 20 \%$ & 0,064 & 0,488 & 0,016 & 0,138 & \\
\hline \multirow{2}{*}{ SOD\% } & $\geq 5 \mathrm{~mm}<20 \%$ & 8,203 & 3,623 & 5,26 & 12,62 & \multirow{2}{*}{0,068} \\
\hline & $\geq 5 \mathrm{~mm} \geq 20 \%$ & 12,084 & 10,880 & 5,26 & 12,62 & \\
\hline
\end{tabular}

\subsection{Analize razlike markera oksidativnog stresa u pljuvački kod pacijenata sa parodontopatijom u zavisnosti od dubine sondiranja pre i posle terapije}

Analizom dobijenih podataka konstatuje se da je parodontolološka terapija dovela do statistički značajnog smanjenja srednjih vrednosti 8-OHdG i MDA u pljuvački kako kod pacijenata sa većom tako i kod pacijenata sa manjom dubinom sondiranja. Srednje vrednosti SOD takođe su snižene u obe ispitivane grupe, s tim da je smanjenje kod pacijenata sa većom dubinom sondiranja bilo i statistički značajno. Iako je promena srednjih vrednosti 8-OHdG, MDA, SOD i \%SOD među ispitivanim grupama pre i posle terapije bila izraženija kod pacijenata sa većom dubinom sondiranja, razlike nisu bile statistički značajne (Tabela 29). 
Tabela 29. Analiza razlike markera oksidativnog stresa u pljuvački kod pacijenata sa parodontopatijom u zavisnosti od dubine sondiranja pre i posle terapije

\begin{tabular}{|c|c|c|c|c|c|c|c|c|}
\hline & & $\begin{array}{l}\text { Pre } \\
\text { terapije } \\
\qquad(\bar{X})\end{array}$ & $\begin{array}{l}\text { Posle } \\
\text { terapije } \\
(\bar{X})\end{array}$ & $\begin{array}{l}\Delta \text { razlika } \\
(\bar{X})\end{array}$ & SG & $\mathbf{p}$ & $\begin{array}{l}95 \% \text { inter } \\
\text { donja } \\
\text { granica }\end{array}$ & $\begin{array}{l}\text { poverenja } \\
\text { gornja } \\
\text { granica }\end{array}$ \\
\hline $\begin{array}{l}\text { 8-OHdG } \\
\text { (ng/ml) }\end{array}$ & $\begin{array}{l}\geq 5 \mathrm{~mm}<20 \% \\
\geq 5 \mathrm{~mm} \geq 20 \%\end{array}$ & $\begin{array}{l}0,700 \\
0,967\end{array}$ & $\begin{array}{l}0,565^{*} \\
0,648^{*}\end{array}$ & $\begin{array}{l}0,135 \\
0,318\end{array}$ & 0,183 & 0,071 & $-0,017$ & 0,384 \\
\hline $\begin{array}{c}\text { MDA } \\
(\mathrm{pmol} / \mu \mathrm{l})\end{array}$ & $\begin{array}{l}\geq 5 \mathrm{~mm}<20 \% \\
\geq 5 \mathrm{~mm} \geq 20 \%\end{array}$ & $\begin{array}{l}2,619 \\
3,207\end{array}$ & $\begin{array}{l}2,087^{*} \\
2,150^{*}\end{array}$ & $\begin{array}{l}0,532 \\
1,058\end{array}$ & 0,294 & 0,084 & $-0,076$ & 1,128 \\
\hline $\begin{array}{l}\text { SOD } \\
(\mathrm{U} / \mu \mathrm{l})\end{array}$ & $\begin{array}{l}\geq 5 \mathrm{~mm}<20 \% \\
\geq 5 \mathrm{~mm} \geq 20 \%\end{array}$ & $\begin{array}{l}0,035 \\
0,227\end{array}$ & $\begin{array}{l}0,032 \\
0,064^{*}\end{array}$ & $\begin{array}{l}0,003 \\
0,163\end{array}$ & 0,160 & 0,182 & $-0,082$ & 0,402 \\
\hline $\operatorname{SOD}(\%)$ & $\begin{array}{l}\geq 5 \mathrm{~mm}<20 \% \\
\geq 5 \mathrm{~mm} \geq 20 \%\end{array}$ & $\begin{array}{l}10,801 \\
16,050\end{array}$ & $\begin{array}{l}8,203 \\
12,084 *\end{array}$ & $\begin{array}{l}2,599 \\
3,966\end{array}$ & $-4,619$ & 0,417 & $-16,105$ & 6,866 \\
\hline
\end{tabular}

*statistički značajna razlika u odnosu na vrednost pre terapije

\subsubsection{MARKERI OKSIDATIVNOG STRESA U PLJUVAČKI KOD PACIJENATA SA PARODONTOPATIJOM U ZAVISNOSTI OD NIVOA PRIPOJNOG EPITELA}

\subsection{Markeri oksidativnog stresa u pljuvački kod pacijenata sa parodontopatijom u zavisnosti od nivoa pripojnog epitela pre terapije}

$\mathrm{Na}$ početku istraživanja pacijenti sa $\mathrm{NPE} \geq 3 \mathrm{~mm}$ imali su veće srednje vrednosti markera oksidativnog stresa $(8-O H d G 0,973 \mathrm{ng} / \mathrm{ml}$, MDA-3,179 pmol/ $\mu 1$, SOD-0,274 U/ $\mu 1, \%$ SOD-15,858) u pljuvački u odnosu na pacijente sa NPE<3mm (8-OHdG 0,667

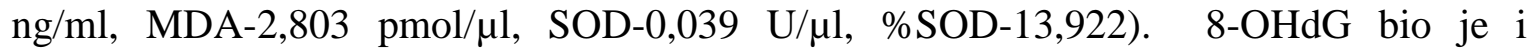
statistički značajno viši ( $\mathrm{p}=0,042)$ kod pacijenata sa NPE $\geq 3 \mathrm{~mm}$, dok razlike u ostalim markerima oksidativnog stresa nisu bile statistički značajne (Tabela 30). 
Tabela 30. Značajnost razlike markera oksidativnog stresa u pljuvački kod pacijenata sa parodontopatijom u zavisnosti od nivoa pripojnog epitela na pre terapije

\begin{tabular}{|c|c|c|c|c|c|c|}
\hline & NPE & $\bar{X}$ & SD & Minimum & Maksimum & $\mathrm{p}$ \\
\hline \multirow{2}{*}{$\begin{array}{c}\text { 8-OHdG } \\
(\mathrm{ng} / \mathrm{ml})\end{array}$} & $<3 \mathrm{~mm}$ & 0,667 & 0,353 & 0,388 & 1,375 & \multirow{2}{*}{0,042} \\
\hline & $\geq 3 \mathrm{~mm}$ & 0,973 & 0,599 & 0,388 & 2,100 & \\
\hline \multirow{2}{*}{$\begin{array}{c}\text { MDA } \\
(\mathrm{pmol} / \mu \mathrm{l})\end{array}$} & $<3 \mathrm{~mm}$ & 2,803 & 0,914 & 1,220 & 4,800 & \multirow{2}{*}{0,512} \\
\hline & $\geq 3 \mathrm{~mm}$ & 3,179 & 1,450 & 1,110 & 4,400 & \\
\hline \multirow{2}{*}{ SOD $(U / \mu 1)$} & $<3 \mathrm{~mm}$ & 0,039 & 0,009 & 0,016 & 0,046 & \multirow{2}{*}{0,187} \\
\hline & $\geq 3 \mathrm{~mm}$ & 0,274 & 0,534 & 0,012 & 1,900 & \\
\hline \multirow{2}{*}{ SOD\% } & $<3 \mathrm{~mm}$ & 13,922 & 2,729 & 5,340 & 17,873 & \multirow{2}{*}{0,187} \\
\hline & $\geq 3 \mathrm{~mm}$ & 15,858 & 13,190 & 2,000 & 39,932 & \\
\hline
\end{tabular}

\subsection{Markeri oksidativnog stresa u pljuvački kod pacijenata sa parodontopatijom u zavisnosti od nivoa pripojnog epitela posle terapije}

Srednje vrednosti markera oksidativnog stresa u grupi pacijenata sa $\mathrm{NPE} \geq 3 \mathrm{~mm}$ posle

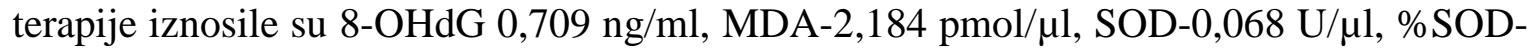
11,347, dok su vrednosti u grupi pacijenata sa NPE $<3 \mathrm{~mm}$ iznosile $8-\mathrm{OHdG} 0,528 \mathrm{ng} / \mathrm{ml}$, MDA-2,091 pmol/ $\mu 1$, SOD-0,037 U/ $\mu 1$, \%SOD-13,807. Iako su kod pacijenata sa NPE $\geq 3 \mathrm{~mm}$ svi markeri izuzev \%SOD bili viši u odnosu na pacijente sa NPE $<3 \mathrm{~mm}$, razlika nije bila statistički značajna ni za jedan ispitivani marker (Tabela 31). 
Tabela 31. Značajnost razlike markera oksidativnog stresa u pljuvački kod pacijenata sa parodontopatijom u zavisnosti od nivoa pripojnog epitela posle terapije

\begin{tabular}{|c|c|c|c|c|c|c|}
\hline & NPE & $\bar{X}$ & SD & Minimum & Maksimum & $\mathrm{p}$ \\
\hline \multirow{2}{*}{$\begin{array}{c}\text { 8-OHdG } \\
(\mathrm{ng} / \mathrm{ml})\end{array}$} & $<3 \mathrm{~mm}$ & 0,528 & 0,259 & 0,246 & 1,150 & \multirow{2}{*}{0,595} \\
\hline & $\geq 3 \mathrm{~mm}$ & 0,709 & 0,463 & 0,246 & 1,625 & \\
\hline \multirow{2}{*}{$\begin{array}{c}\text { MDA } \\
(\mathrm{pmol} / \mu \mathrm{l})\end{array}$} & $<3 \mathrm{~mm}$ & 2,091 & 0,740 & 1,110 & 3,300 & \multirow{2}{*}{0,744} \\
\hline & $\geq 3 \mathrm{~mm}$ & 2,184 & 1,147 & 1,110 & 4,800 & \\
\hline \multirow{2}{*}{$\operatorname{SOD}(U / \mu l)$} & $<3 \mathrm{~mm}$ & 0,037 & 0,032 & 0,016 & 0,138 & \multirow{2}{*}{0,147} \\
\hline & $\geq 3 \mathrm{~mm}$ & 0,068 & 0,055 & 0,016 & 0,138 & \\
\hline \multirow{2}{*}{ SOD \% } & $<3 \mathrm{~mm}$ & 13,807 & 12,292 & 5,341 & 12,621 & \multirow{2}{*}{0,840} \\
\hline & $\geq 3 \mathrm{~mm}$ & 11,347 & 5,779 & 5,341 & 12,621 & \\
\hline
\end{tabular}

\subsection{Analiza razlike markera oksidativnog stresa u pljuvački kod pacijenata sa parodontopatijom u zavisnosti od nivoa pripojnog epitela pre i posle terapije}

Analizom dobijenih rezultata konstatuje se da su posle terapije srednje vrednosti 8OHdG, MDA, SOD i \%SOD bile niže kako kod pacijenata sa NPE $\geq 3 \mathrm{~mm}$, tako i kod pacijenata sa NPE $<3 \mathrm{~mm}$. Smanjenje 8-OHdG i MDA bilo je statistički značajno u obe grupe pacijenata, dok su SOD i \%SOD značajno smanjeni samo u grupi pacijenata sa NPE $\geq 3 \mathrm{~mm}$. Iako je promena vrednosti svih ispitivanih markera oksidativnog stresa pre i posle terapije bila veća u grupi pacijenata sa NPE $\geq 3 \mathrm{~mm}$ razlike nisu bile statistički značajne (Tabela 32). 
Tabela 32. Analiza razlike markera oksidativnog stresa u pljuvački kod pacijenata sa parodontopatijom u zavisnosti od nivoa pripojnog epitela pre i posle terapije

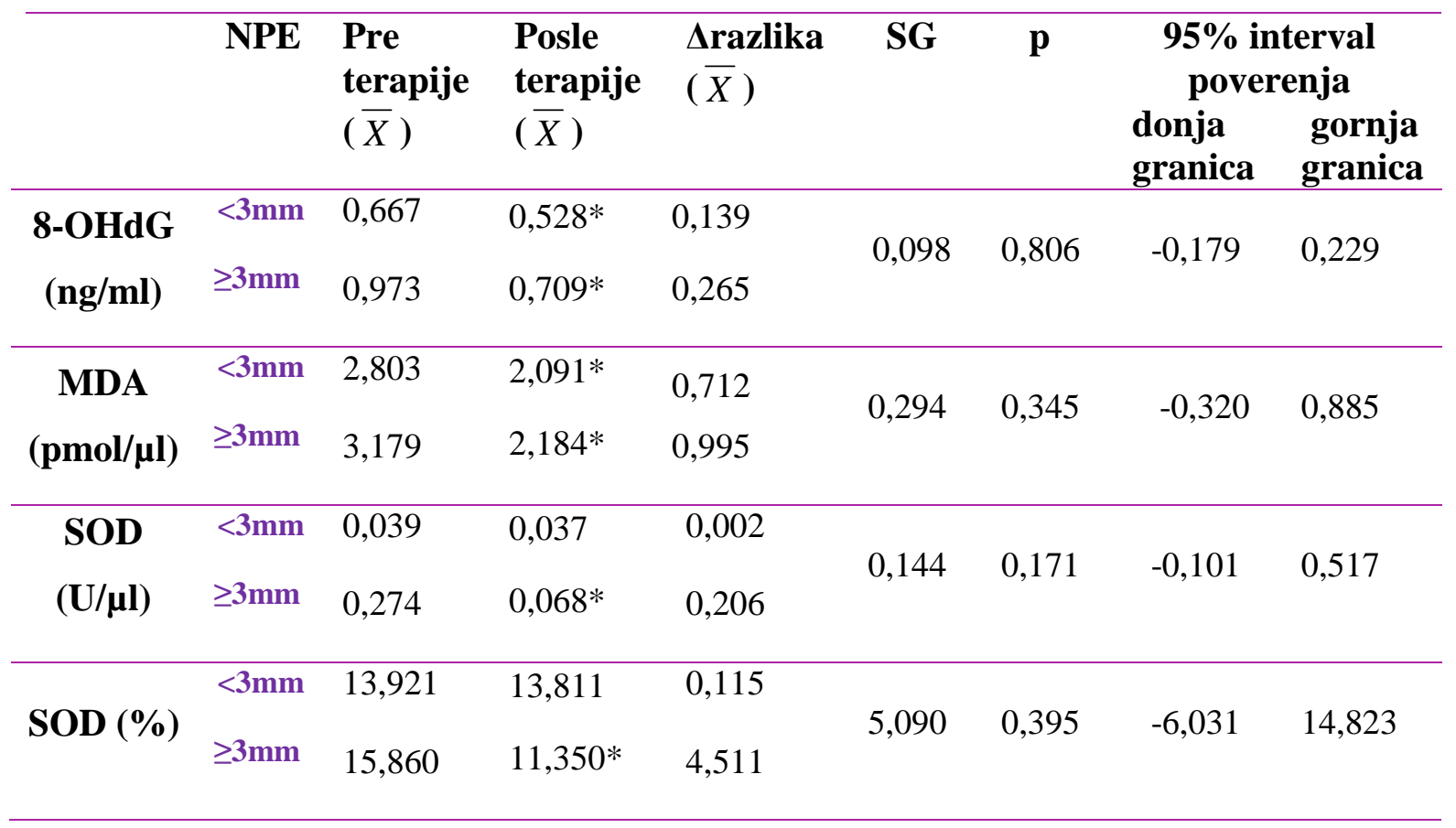

*statistički značajna razlika u odnosu na vrednost pre terapije

\subsubsection{MARKERI OKSIDATIVNOG STRESA U KRVI KOD PACIJENATA SA PARODONTOPATIJOM U ZAVISNOSTI OD PARODONTOLOŠKOG STATUSA}

\subsubsection{MARKERI OKSIDATIVNOG STRESA U KRVI KOD PACIJENATA SA PARODONTOPATIJOM U ZAVISNOSTI OD STEPENA INFLAMACIJE GINGIVE}

\subsection{Markeri oksidativnog stresa u krvi kod pacijenata sa parodontopatijom u} zavisnosti od stepena inflamacije gingive pre terapije

Kod pacijenata sa izraženom inflamacijom gingive na početku istraživanja zabeležene su više srednje vrednosti svih ispitivanih markera oksidativnog stresa u odnosu na pacijente sa umerenom inflamacijom. Tako je srednja vrednost MDA $(0,548 \mathrm{pmol} / \mu \mathrm{l}) \mathrm{u}$ grupi pacijenata sa izraženom inflamacijom statistički značajno viša $(p=0,047)$ u odnosu 
na vrednost $(0,451 \mathrm{pmol} / \mu \mathrm{l})$ u grupi pacijenata sa umerenom inflamacijom. Razlike između srednjih vrednosti ostalih markera kod pacijenata sa izraženom inflamacijom (8-

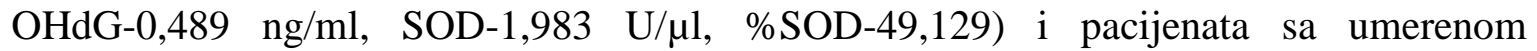

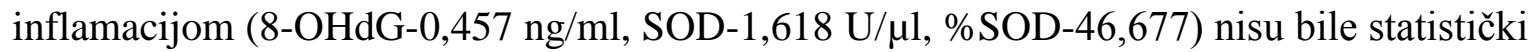
značajne (Tabela 33).

Tabela 33. Značajnost razlike markera oksidativnog stresa u krvi kod pacijenata sa parodontopatijom u zavisnosti od stepena inflamacije gingive pre terapije

\begin{tabular}{ccccccc}
\hline & Forma & $\bar{X}$ & SD & Minimum & Maksimum & $\mathrm{p}$ \\
& inflamacije & & & & & \\
\hline $\begin{array}{c}\mathbf{8 - O H d G} \\
(\mathrm{ng} / \mathrm{ml})\end{array}$ & Umerena & 0,457 & 0,198 & 0,165 & 0,812 & 0,622 \\
& Izražena & 0,489 & 0,153 & 0,165 & 0,812 & \\
\hline $\begin{array}{c}\text { MDA } \\
(\mathrm{pmol} / \mu \mathrm{l})\end{array}$ & Umerena & 0,451 & 0,122 & 0,290 & 0,650 & $\mathbf{0 , 0 4 7}$ \\
& Izražena & 0,548 & 0,132 & 0,370 & 0,750 & \\
\hline SOD $(\mathrm{U} / \mu \mathrm{l})$ & Umerena & 1,618 & 1,704 & 0,118 & 5,500 & 0,583 \\
& Izražena & 1,983 & 1.892 & 0,582 & 6,900 & \\
\hline SOD\% & Umerena & 46,677 & 12,728 & 28,790 & 70,861 & 0,604 \\
& Izražena & 49,129 & 12,855 & 37,811 & 80,090 & \\
\hline
\end{tabular}

\subsection{Markeri oksidativnog stresa u krvi kod pacijenata sa parodontopatijom u zavisnosti od stepena inflamacije gingive posle terapije}

Posle sprovedene parodontološke terapije, vrednosti markera oksidativnog stresa kod pacijenata sa izraženom inflamacijom gingive su i dalje više nego kod pacijenata sa umerenom inflamacijom ali te razlike nisu bile na statistički značajnom nivou. Izuzetak čini MDA koji i nakon terapije ostaje statistički značajno viši $(\mathrm{p}=0,038)$ kod pacijenata sa izraženom inflamacijom (Tabela 34). 
Tabela 34. Značajnost razlike markera oksidativnog stresa u krvi kod pacijenata sa parodontopatijom u zavisnosti od stepena inflamacije gingive posle terapije

\begin{tabular}{ccccccc}
\hline & Forma & $\bar{X}$ & SD & Minimum & Maksimum & $\mathrm{p}$ \\
& inflamacije & & & & & \\
\hline $\begin{array}{c}\text { 8-OHdG } \\
(\mathrm{ng} / \mathrm{ml})\end{array}$ & Umerena & 0,445 & 0,176 & 0,202 & 0,750 & 0,833 \\
& Izražena & 0,460 & 0,186 & 0,165 & 0,775 & \\
\hline $\begin{array}{c}\text { MDA } \\
(\mathrm{pmol} / \mu \mathrm{l})\end{array}$ & Umerena & 0,425 & 0,122 & 0,220 & 0,700 & $\mathbf{0 , 0 3 8}$ \\
& Izražena & 0,510 & 0,087 & 0,370 & 0,620 & \\
\hline SOD $(\mathrm{U} / \mu \mathrm{l})$ & Umerena & 1,612 & 1,539 & 0,226 & 6,300 & 0,604 \\
& Izražena & 1,954 & 1,059 & 0,284 & 4,000 & \\
\hline SOD\% & Umerena & 46,311 & 11,891 & 33,280 & 83,090 & 0,654 \\
& Izražena & 47,833 & 6,409 & 37,500 & 62,000 & \\
\hline
\end{tabular}

\subsection{Analiza razlike markera oksidativnog stresa u krvi kod pacijenata sa parodontopatijom u zavisnosti od stepena inflamacije pre i posle terapije}

Analizom dobijenih rezultata može se konstatovati da je parodontolološka terapija dovela do smanjenja srednjih vrednosti svih ispitivanih markera oksidativnog stresa kako u grupi pacijenata sa izraženom, tako i u grupi sa umerenom formom inflamacije, međutim ni jedno smanjenje nije bilo na statistički značajnom nivou. Isto tako, ni razlika u promeni srednjih vrednosti ispitivanih markera pre i posle terapije između grupa nije bila statistički značajna (Tabela 35). 
Tabela 35. Analiza razlike markera oksidativnog stresa u krvi kod pacijenata sa umerenom i izraženom inflamacijom gingive pre i posle terapije

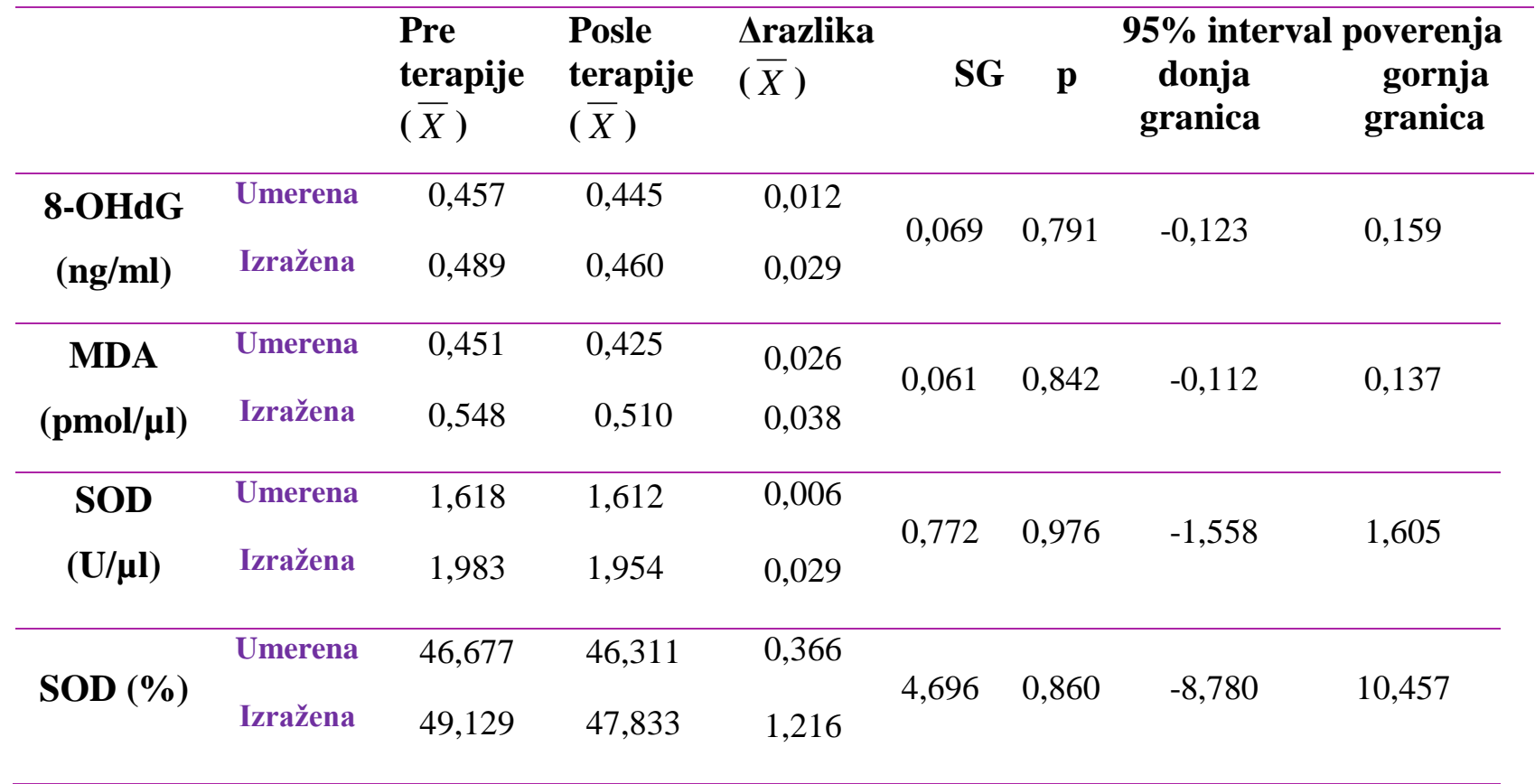

\subsubsection{MARKERI OKSIDATIVNOG STRESA U KRVI KOD PACIJENATA SA PARODONTOPATIJOM U ZAVISNOSTI OD DUBINE SONDIRANJA}

\subsection{Markeri oksidativnog stresa u krvi kod pacijenata sa parodontopatijom u zavisnosti od dubine sondiranja pre terapije}

$\mathrm{Na}$ početku istraživanja markeri oksidativnog stresa $\mathrm{u}$ krvi pacijenata sa većom dubinom sondiranja bili su viši u odnosu na pacijente sa manjom dubinom sondiranja. Tako je srednja vrednost MDA u grupi pacijenata sa $\mathrm{DS} \geq 5 \mathrm{~mm} \geq 20 \%$ iznosila 0,529 $\mathrm{pmol} / \mu \mathrm{l}$, a u grupi pacijenata $\mathrm{DS} \geq 5 \mathrm{~mm}<20 \%$ 0,441 $\mathrm{pmol} / \mu \mathrm{l}$, međutim ova razlika nije bila statistički značajna $(p=0,083)$. Ni srednje vrednosti ostalih markera, iako takođe više kod pacijenata sa većom dubinom sondiranja, nisu se statistički značajno razlikovale od vrednosti kod pacijenata sa manjom dubinom sondiranja (Tabela 36). 
Tabela 36. Značajnost razlike markera oksidativnog stresa u krvi kod pacijenata sa parodontopatijom u zavisnosti od dubine sondiranja pre terapije

\begin{tabular}{|c|c|c|c|c|c|c|}
\hline & $\mathrm{DS}$ & $\bar{X}$ & $\mathrm{SD}$ & Minimum & Maksimum & $\mathrm{p}$ \\
\hline \multirow{2}{*}{$\begin{array}{c}\text { 8-OHdG } \\
(\mathrm{ng} / \mathrm{ml})\end{array}$} & $\geq 5 \mathrm{~mm}<20 \%$ & 0,427 & 0,199 & 0,165 & 0,812 & \multirow{2}{*}{0,301} \\
\hline & $\geq 5 \mathrm{~mm} \geq \mathbf{2 0} \%$ & 0,498 & 0,162 & 0,165 & 0,812 & \\
\hline \multirow{2}{*}{$\begin{array}{c}\text { MDA } \\
(\mathrm{pmol} / \mu \mathrm{l})\end{array}$} & $\geq 5 \mathrm{~mm}<20 \%$ & 0,441 & 0,122 & 0,290 & 0,650 & \multirow{2}{*}{0,083} \\
\hline & $\geq 5 \mathrm{~mm} \geq \mathbf{2 0} \%$ & 0,529 & 0,123 & 0,290 & 0,700 & \\
\hline \multirow{2}{*}{$\operatorname{SOD}(U / \mu l)$} & $\geq 5 \mathrm{~mm}<20 \%$ & 1,748 & 1,453 & 0,166 & 5,500 & \multirow{2}{*}{0,927} \\
\hline & $\geq 5 \mathrm{~mm} \geq 20 \%$ & 1,812 & 1,972 & 0,198 & 6,900 & \\
\hline \multirow{2}{*}{ SOD\% } & $\geq 5 \mathrm{~mm}<20 \%$ & 47,762 & 11,132 & 30,661 & 70,860 & \multirow{2}{*}{0,972} \\
\hline & $\geq 5 \mathrm{~mm} \geq 20 \%$ & 47,931 & 13,711 & 33,102 & 80,091 & \\
\hline
\end{tabular}

\subsection{Markeri oksidativnog stresa u krvi kod pacijenata sa parodontopatijom u zavisnosti od dubine sondiranja posle terapije}

Dobijeni rezultati pokazuju da su posle terapije srednje vrednosti markera oksidativnog stresa u krvi pacijenata sa većom dubinom sondiranja i dalje više nego kod pacijenata sa manjom dubinom sondiranja, ali da te razlike nisu bile na statistički značajnom novou. Najveća razlika između posmatranih grupa zapaža se kod 8-OHdG. Naime, srednja vrednost 8 -OHdG u krvi pacijenata sa $\mathrm{DS} \geq 5 \mathrm{~mm} \geq 20 \%$ je nakon terapije iznosila $0,491 \mathrm{ng} / \mathrm{ml}$, dok je njegova vrednost kod pacijenata sa $\mathrm{DS} \geq 5 \mathrm{~mm}<20 \%$ bila 0,376 $\mathrm{ng} / \mathrm{ml}(\mathrm{p}=0,086)$ (Tabela 37). 
Tabela 37. Značajnost razlike markera oksidativnog stresa u krvi kod pacijenata sa parodontopatijom u zavisnosti od dubine sondiranja posle terapije

\begin{tabular}{|c|c|c|c|c|c|c|}
\hline & $\mathrm{DS}$ & $\bar{X}$ & SD & Minimum & Maksimum & $\mathrm{p}$ \\
\hline \multirow{2}{*}{$\begin{array}{c}\text { 8-OHdG } \\
(\mathrm{ng} / \mathrm{ml})\end{array}$} & $\geq 5 \mathrm{~mm}<20 \%$ & 0,376 & 0,173 & 0,388 & 0,675 & \multirow{2}{*}{0,086} \\
\hline & $\geq 5 \mathrm{~mm} \geq 20 \%$ & 0,491 & 0,168 & 0,268 & 0,775 & \\
\hline \multirow{2}{*}{$\begin{array}{c}\text { MDA } \\
(\mathrm{pmol} / \mu \mathrm{l})\end{array}$} & $\geq 5 \mathrm{~mm}<20 \%$ & 0,418 & 0,124 & 0,220 & 0,700 & \multirow{2}{*}{0,563} \\
\hline & $\geq 5 \mathrm{~mm} \geq 20 \%$ & 0,455 & 0,109 & 0,250 & 0,620 & \\
\hline \multirow{2}{*}{$\operatorname{SOD}(U / \mu l)$} & $\geq 5 \mathrm{~mm}<20 \%$ & 1,699 & 1,117 & 0,234 & 3,500 & \multirow{2}{*}{0,824} \\
\hline & $\geq 5 \mathrm{~mm} \geq 20 \%$ & 1,810 & 1,461 & 0,226 & 6,300 & \\
\hline \multirow{2}{*}{ SOD \% } & $\geq 5 \mathrm{~mm}<20 \%$ & 44,849 & 6,991 & 33,450 & 55,000 & \multirow{2}{*}{0,326} \\
\hline & $\geq 5 \mathrm{~mm} \geq \mathbf{2 0} \%$ & 47,060 & 11,112 & 33,280 & 83,091 & \\
\hline
\end{tabular}

\subsection{Analiza razlike markera oksidativnog stresa u krvi kod pacijenata sa parodontopatijom u zavisnosti od dubine sondiranja pre i posle terapije}

Analizom dobijenih rezultata konstatuje se da je parodontolološka terapija dovela do smanjenja svih ispitivanih markera oksidativnog stresa u krvi kako u grupi pacijenata sa većom tako i u grupi pacijenata sa manjom dubinom sondiranja, ali da je samo smanjenje vrednosti MDA u krvi pacijenata sa većom dubinom sondiranja bilo na statistički značajnom nivou $(\mathrm{p}=0,025)$. Konstatuje se i da razlika u promeni srednjih vrednosti 8-OHdG, MDA, SOD i \%SOD pre i posle terapije među ispitivanim grupama nije bila statistički značajna (Tabela 38 ). 
Tabela 38. Analiza razlike markera oksidativnog stresa u krvi kod pacijenata sa parodontopatijom u zavisnosti od dubine sondiranja pre i posle terapije

\begin{tabular}{|c|c|c|c|c|c|c|c|c|}
\hline & & $\begin{array}{l}\text { Pre } \\
\text { terapije } \\
\qquad(\bar{X})\end{array}$ & $\begin{array}{l}\text { Posle } \\
\text { terapije } \\
(\bar{X})\end{array}$ & $\begin{array}{l}\Delta \text { razlika } \\
(\bar{X})\end{array}$ & SG & $\mathbf{p}$ & $\begin{array}{l}95 \% \text { inter } \\
\text { donja } \\
\text { granica }\end{array}$ & $\begin{array}{l}\text { poverenja } \\
\text { gornja } \\
\text { granica }\end{array}$ \\
\hline $\begin{array}{c}\text { 8-OHdG } \\
(\mathrm{ng} / \mathrm{ml})\end{array}$ & $\begin{array}{l}\geq 5 \mathrm{~mm}<20 \% \\
\geq 5 \mathrm{~mm} \geq 20 \%\end{array}$ & $\begin{array}{l}0,427 \\
0,498\end{array}$ & $\begin{array}{l}0,376 \\
0,491\end{array}$ & $\begin{array}{l}0,051 \\
0,007\end{array}$ & 0,063 & 0,487 & $-0,173$ & 0,084 \\
\hline $\begin{array}{c}\text { MDA } \\
(\mathrm{pmol} / \mu \mathrm{l})\end{array}$ & $\begin{array}{l}\geq 5 \mathrm{~mm}<20 \% \\
\geq 5 \mathrm{~mm} \geq 20 \%\end{array}$ & $\begin{array}{l}0,441 \\
0,529\end{array}$ & $\begin{array}{l}0,418 \\
0,455^{*}\end{array}$ & $\begin{array}{l}0,023 \\
0,074\end{array}$ & 0,059 & 0,066 & $-0,008$ & 0,235 \\
\hline $\begin{array}{l}\text { SOD } \\
(\mathrm{U} / \mu \mathrm{l})\end{array}$ & $\begin{array}{l}\geq 5 \mathrm{~mm}<20 \% \\
\geq 5 \mathrm{~mm} \geq 20 \%\end{array}$ & $\begin{array}{l}1,748 \\
1,812\end{array}$ & $\begin{array}{l}1,699 \\
1,810\end{array}$ & $\begin{array}{l}0,049 \\
0,002\end{array}$ & 0,793 & 0,949 & $-1,675$ & 1,572 \\
\hline $\operatorname{SOD}(\%)$ & $\begin{array}{l}\geq 5 \mathrm{~mm}<20 \% \\
\geq 5 \mathrm{~mm} \geq 20 \%\end{array}$ & $\begin{array}{l}47,762 \\
47,931\end{array}$ & $\begin{array}{l}44,849 \\
47,060\end{array}$ & $\begin{array}{l}2,913 \\
0,871\end{array}$ & 5,064 & 0,448 & $-14,267$ & 6,478 \\
\hline
\end{tabular}

*statistički značajna razlika u odnosu na vrednost pre terapije

5.3.2.3. MARKERI OKSIDATIVNOG STRESA U KRVI KOD PACIJENATA SA PARODONTOPATIJOM U ZAVISNOSTI OD NIVOA PRIPOJNOG EPITELA

\subsection{Markeri oksidativnog stresa u krvi kod pacijenata sa parodontopatijom u zavisnosti od nivoa pripojnog epitela pre terapije}

$\mathrm{Na}$ početku istraživanja pacijenti sa NPE $\geq 3 \mathrm{~mm}$ imali su više srednje vrednosti svih ispitivanih markera oksidativnog stresa (8-OHdG-0,502 ng/ml, MDA-0,537 $\mathrm{pmol} / \mu \mathrm{l}$,

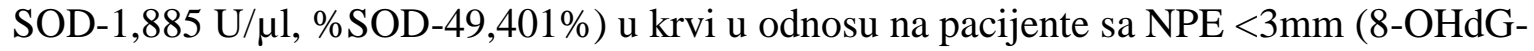

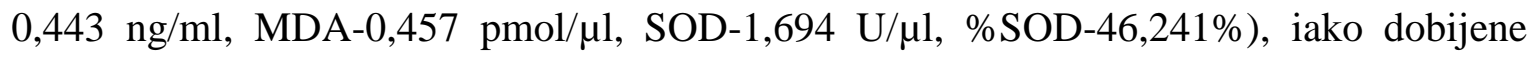
razilike nisu bile na statistički značajnom nivou (Tabela 39). 
Tabela 39. Značajnost razlike markera oksidativnog stresa u krvi kod pacijenata sa parodontopatijom u zavisnosti od nivoa pripojnog epitela pre terapije

\begin{tabular}{|c|c|c|c|c|c|c|}
\hline & NPE & $\bar{X}$ & SD & Minimum & Maksimum & $\mathrm{p}$ \\
\hline \multirow{2}{*}{$\begin{array}{c}\text { 8-OHdG } \\
(\mathrm{ng} / \mathrm{ml})\end{array}$} & $<3 \mathrm{~mm}$ & 0,443 & 0,148 & 0,165 & 2,575 & \multirow{2}{*}{0,365} \\
\hline & $\geq 3 \mathrm{~mm}$ & 0,502 & 0,201 & 0,224 & 0,812 & \\
\hline \multirow{2}{*}{$\begin{array}{c}\text { MDA } \\
(\mathrm{pmol} / \mu \mathrm{l})\end{array}$} & $<3 \mathrm{~mm}$ & 0,457 & 0,129 & 0,290 & 0,700 & \multirow{2}{*}{0,103} \\
\hline & $\geq 3 \mathrm{~mm}$ & 0,537 & 0,131 & 0,370 & 0,750 & \\
\hline \multirow{2}{*}{ SOD $(U / \mu 1)$} & $<3 \mathrm{~mm}$ & 1,694 & 1,621 & 0,118 & 5,500 & \multirow{2}{*}{0,774} \\
\hline & $\geq 3 \mathrm{~mm}$ & 1,885 & 1,964 & 0,198 & 6,900 & \\
\hline \multirow{2}{*}{ SOD\% } & $<3 \mathrm{~mm}$ & 46,241 & 11,802 & 28,791 & 70,862 & \multirow{2}{*}{0,503} \\
\hline & $\geq 3 \mathrm{~mm}$ & 49,401 & 11,350 & 33,100 & 80,090 & \\
\hline
\end{tabular}

\subsection{Markeri oksidativnog stresa u krvi kod pacijenata sa parodontopatijom u zavisnosti od nivoa pripojnog epitela posle terapije}

Srednje vrednosti markera oksidativnog stresa u grupi pacijenata sa $\mathrm{NPE} \geq 3 \mathrm{~mm}$ posle

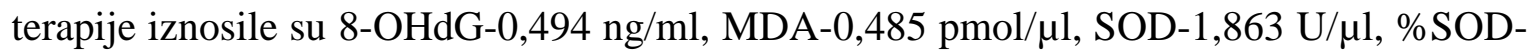
$47,081 \%$, dok su vrednosti u grupi pacijenata sa NPE $<3 \mathrm{~mm}$ iznosile 8 -OHdG 0,403 ng/ml, MDA-0,444 pmol/ $\mu 1$, SOD-1,651 U/ $\mu 1, \%$ SOD-45,041\%. Iako su kod pacijenata sa $\mathrm{NPE} \geq 3 \mathrm{~mm}$ svi markeri bili viši u odnosu na pacijente sa $\mathrm{NPE}<3 \mathrm{~mm}$, razlika nije bila statistički značajna ni za jedan ispitivani marker (Tabela 40). 


\section{Rezultati}

Tabela 40. Značajnost razlike markera oksidativnog stresa u krvi kod pacijenata sa parodontopatijom u zavisnosti od nivoa pripojnog epitela posle terapije

\begin{tabular}{|c|c|c|c|c|c|c|}
\hline & NPE & $\bar{X}$ & SD & Minimum & Maksimum & $\mathrm{p}$ \\
\hline \multirow{2}{*}{$\begin{array}{c}\text { 8-OHdG } \\
(\mathrm{ng} / \mathrm{ml})\end{array}$} & $<3 \mathrm{~mm}$ & 0,403 & 0,164 & 0,165 & 0,750 & \multirow{2}{*}{0,165} \\
\hline & $\geq 3 \mathrm{~mm}$ & 0,494 & 0,183 & 0,202 & 0,775 & \\
\hline \multirow{2}{*}{$\begin{array}{c}\text { MDA } \\
(\mathrm{pmol} / \mu \mathrm{l})\end{array}$} & $<3 \mathrm{~mm}$ & 0,444 & 0,077 & 0,350 & 0,600 & \multirow{2}{*}{0,327} \\
\hline & $\geq 3 \mathrm{~mm}$ & 0,485 & 0,141 & 0,220 & 0,700 & \\
\hline \multirow{2}{*}{ SOD $(U / \mu 1)$} & $<3 \mathrm{~mm}$ & 1,651 & 0,656 & 1,122 & 3,500 & \multirow{2}{*}{0,628} \\
\hline & $\geq 3 \mathrm{~mm}$ & 1,863 & 1,785 & 0,226 & 6,300 & \\
\hline \multirow{2}{*}{ SOD \% } & $<3 \mathrm{~mm}$ & 45,041 & 3,970 & 43,691 & 55,000 & \multirow{2}{*}{0,892} \\
\hline & $\geq 3 \mathrm{~mm}$ & 47,081 & 13,240 & 33,282 & 83,090 & \\
\hline
\end{tabular}

\subsection{Analiza razlike markera oksidativnog stresa u krvi kod pacijenata sa} parodontopatijom u zavisnosti od nivoa pripojnog epitela pre i posle terapije

Analizom dobijenih rezultata može se konstatovati da je parodontolološka terapija dovela do smanjenja srednjih vrednosti svih ispitivanih markera oksidativnog stresa kako u grupi pacijenata sa $\mathrm{NPE} \geq 3 \mathrm{~mm}$, tako i u grupi sa $\mathrm{NPE}<3 \mathrm{~mm}$, međutim ni jedno smanjenje nije bilo na statistički značajnom nivou. Isto tako, ni razlika u promeni srednjih vrednosti ispitivanih markera pre i posle terapije između grupa nije bila statistički značajna (Tabela 41). 
Tabela 41. Analiza razlike markera oksidativnog stresa u krvi kod pacijenata sa parodontopatijom u zavisnosti od nivoa pripojnog epitela pre i posle terapije

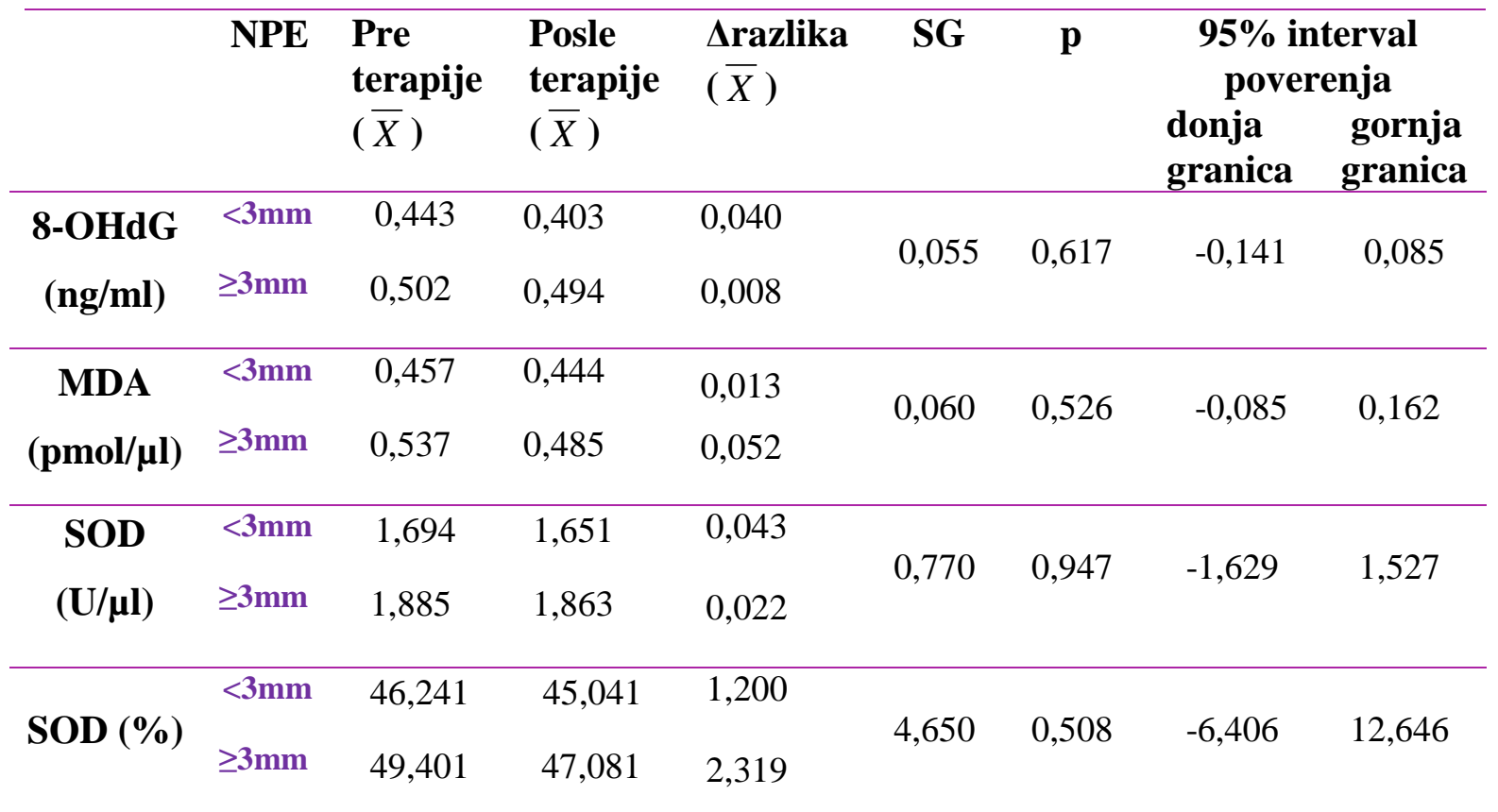

\subsection{MARKERI OKSIDATIVNOG STRESA U ODNOSU NA NAVIKU PUŠENJA}

Imajući u vidu prooksidativni efekat duvanskog dima, u grupi pacijenata sa parodontopatijom su posebno analizirani markeri oksidativnog stresa u odnosu na naviku pušenja kao i efekti parodontološke terapije na antioksidativni potencijal i oksidativni stres kod pušača i nepušača. U grupi pacijenata sa parodontopatijom bilo je 10 pušača i 20 nepušača. 


\subsubsection{Markeri oksidativnog stresa u pljuvački kod pušača i nepušača sa parodontopatijom}

Dobijeni rezultati pokazuju statistički značajno više vrednosti svih ispitivanih markera oksidativnog stresa u pljuvački u grupi pušača u odnosu na nepušače na početku istraživanja. Tako je srednja vrednost $8-\mathrm{OHdG}$ bila $1,181 \mathrm{ng} / \mathrm{ml} \mathrm{kod}$ pušača, a $0,713 \mathrm{ng} / \mathrm{ml}$ kod nepušača, dok je srednja vrednost MDA iznosila 4,069 pmol/ $\mu 1$ kod pušača a 2,461

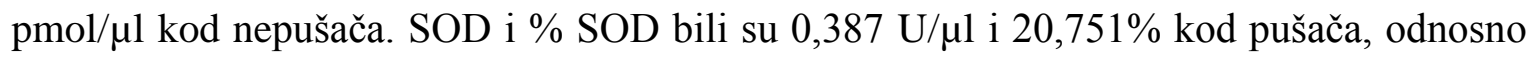
0,041 U/Ml i 11,961\% kod nepušača. Posle terapije, svi markeri oksidativnog stresa u pljuvački pušača beleže statistički značajan pad. I u grupi nepušača 8-OHdG i MDA značajno su smanjeni nakon terapije, dok SOD i \%SOD beleže blagi porast ali bez statističke značajnosti. Poređenjem srednjih vrednosti ispitivanih markera u grupi pušača i nepušača posle terapije, zapažaju se i dalje statistički značajno više srednje vrednosti 8OHdG i MDA u grupi pušača (Tabela 42).

Tabela 42. Markeri oksidativnog stresa u pljuvački kod pušača i nepušača sa parodontopatijom

\begin{tabular}{cccc}
\hline & & $\begin{array}{c}\text { Pušači } \\
(\bar{X} \pm \text { SD })\end{array}$ & $\begin{array}{c}\text { Nepušači } \\
(\bar{X} \pm \text { SD })\end{array}$ \\
\hline $\begin{array}{c}\mathbf{8 - O H d G} \\
(\mathbf{n g} / \mathbf{m l})\end{array}$ & Pre terapije & $1,181 \pm 0,600$ & $0,713 \pm 0,354^{\mathrm{b}}$ \\
\hline $\begin{array}{c}\text { MDA } \\
(\mathbf{p m o l} / \boldsymbol{\mu l})\end{array}$ & Posle terapije & $0,927 \pm 0,422^{\mathrm{a}}$ & $0,463 \pm 0,245^{\mathrm{ab}}$ \\
\hline $\begin{array}{c}\text { SOD } \\
\mathbf{( U / \mu l )}\end{array}$ & Posle terapije & $2,680 \pm 0,860^{\mathrm{a}}$ & $1,872 \pm 0,891^{\mathrm{ab}}$ \\
\hline POD terapije & $0,387 \pm 0,630$ & $0,041 \pm 0,052^{\mathrm{b}}$ \\
\hline & Posle terapije & $0,027 \pm 0,110^{\mathrm{a}}$ & $0,052 \pm 0,053$ \\
\hline & Pre terapije & $20,751 \pm 11,681$ & $11,961 \pm 6,592^{\mathrm{b}}$ \\
\hline & Posle terapije & $10,060 \pm 4,581^{\mathrm{a}}$ & $12,792 \pm 7,000$ \\
\hline
\end{tabular}

\footnotetext{
${ }^{\mathrm{a}}$ statistički značajna razlika u odnosu na vrednost pre terapije

${ }^{\mathrm{b}}$ statistički značajna razlika u odnosu na vrednost kod pušača
} 


\subsubsection{Markeri oksidativnog stresa u krvi kod pušača i nepušača sa parodontopatijom}

Dobijeni rezultati pokazuju da su u krvi pacijenata sa parodontopatijom na početku istraživanja zabeležene statistički značajno više srednje vrednosti MDA, SOD i \%SOD u grupi pušača u odnosu na nepušače. I srednja vrednost 8-OHdG kod pušača $(0,556$ ng/ml) bila je viša nego kod nepušača $(0,430 \mathrm{ng} / \mathrm{ml})$ iako razlika nije dostigla statistički značajan nivo $(\mathrm{p}=0,214)$. Posle terapije došlo je do pada vrednosti svih ispitivanih markera oksidativnog stresa u grupi pušača da bi vrednost MDA bila i statistički značajno niža. U grupi nepušača 8-OHdG i MDA beleže blagi pad a SOD i \%SOD blagi porast nakon terapije. Poređenjem vrednosti ispitivanih markera u grupi pušača i nepušača posle terapije, zapažaju se i dalje statistički značajno više srednje vrednosti SOD i \%SOD u grupi pušača (Tabela 43).

Tabela 43. Markeri oksidativnog stresa u krvi pušača i nepušača sa parodontopatijom

\begin{tabular}{|c|c|c|c|}
\hline & & $\begin{array}{c}\text { Pušači } \\
(\bar{X} \pm \text { SD })\end{array}$ & $\begin{array}{l}\text { Nepušači } \\
(\bar{X} \pm \text { SD })\end{array}$ \\
\hline \multirow{2}{*}{$\begin{array}{c}\text { 8-OHdG } \\
(\mathrm{ng} / \mathrm{ml})\end{array}$} & Pre terapije & $0,556 \pm 0,205$ & $0,430 \pm 0,148$ \\
\hline & Posle terapije & $0,507 \pm 0,185$ & $0,419 \pm 0,168$ \\
\hline \multirow{2}{*}{$\begin{array}{c}\text { MDA } \\
(\mathrm{pmol} / \mu \mathrm{l})\end{array}$} & Pre terapije & $0,570 \pm 0,121$ & $0,460 \pm 0,131^{b}$ \\
\hline & Posle terapije & $0,480 \pm 0,008^{\mathrm{a}}$ & $0,450 \pm 0,131$ \\
\hline \multirow{2}{*}{$\begin{array}{l}\text { SOD } \\
(\mathrm{U} / \mu \mathrm{l})\end{array}$} & Pre terapije & $2,920 \pm 2,675$ & $1,223 \pm 0,629^{b}$ \\
\hline & Posle terapije & $2,700 \pm 1,731$ & $1,307 \pm 0,764^{\mathrm{b}}$ \\
\hline \multirow{2}{*}{ SOD $(\%)$} & Pre terapije & $56,190 \pm 17,590$ & $43,641 \pm 6,450^{b}$ \\
\hline & Posle terapije & $52,421 \pm 12,650$ & $44,380 \pm 6,501^{\mathrm{b}}$ \\
\hline
\end{tabular}




\section{DISKUSIJA}

Savremena medicina poklanja sve više pažnje oksidativnom stresu kao biohemijskom mehanizmu potencijalno uključenom $\mathrm{u}$ patogenetska zbivanja $\mathrm{u}$ velikom broju sistemskih bolesti.

Istraživanja pokazuju da je od svih funkcionalnih sistema CNS najpodložniji stvaranju slobodnih radikala, a istovremeno i najosetljiviji na njihovo dejstvo. Ovo je uslovljeno, pre svega, činjenicom da mozak ima najveću potrebu za energijom, što uzrokuje i najintenzivnije procese oksidativne fosforilacije, dok ga visok procenat polinezasićenih masnih kiselina čini posebno osetljivim na dejstvo slobodnih radikala (146).

Oksidativni stres se dovodi u vezu sa nastankom ateroskleroze preko serije promena tipa oksidativne modifikacije LDL i peroksidacije lipida koje dovode do poremećaja metabolizma holesterola u ćelijama zida arterija, agregacije oksidisanih lipidnih čestica i pojave aterosklerotičnih lezija $(147,148)$. Nadalje, istraživanja pokazuju da je u akutnom infarktu miokarda povećana produkcija vodonik-peroksida, hipohlorne kiseline i drugih reaktivnih metabolita (149), te da je u sinovijalnoj tečnosti pacijenata sa reumatoidnim artritisom dva puta veća koncentracija produkata oksidativnog oštećenja proteina (150).

Oksidativni stres se označava kao mogući uzrok nastanka insulinske rezistencije (151-153), kao i mehanizam kojim poremećen metabolizam glukoze i disregulacija ćelijske signalizacije dovode do razvoja komplikacija u dijabetesu, indukujući pre svega mikro i makroangiopatiju (154).

Visok nivo lipidne peroksidacije detektovan je u krvi trudnica sa preeklampsijom $(155,156)$, a oksidativno oštećenje lipida dovodi se u vezu i sa spontanim pobačajem (157). I na kraju, dokazano je da prooksidantni status ćelija, nastao povećanjem koncentracije slobodnih radikala ili smanjenjem antioksidativne zaštite može ubrzati neoplastični rast (158). 


\section{Diskusija}

Inflamatorna oboljenja parodoncijuma su nesumnjivo jedna od najčešćih oboljenja savremenog čoveka. Njihova učestalost prema »Beogradskoj studiji«, u domaćoj populaciji među osobama starijim od 18 godina iznosi $84,6 \%$. Od ovog broja 44,8\% ima ostećenje dubljih parodontalnih tkiva i formirane parodontalne džepove. Blagi stepen destrukcije parodoncijuma prisutan je kod 14,1\% osoba, srednji kod 20,3\%, dok najteža ostećenja ima 10,4\% ispitanika (159). Parodontopatija srednjeg ili teškog oblika je prisutna kod oko 15\% Amerikanaca starijih od 18 godina a slična učestalost se viđa i u većini drugih zemalja (160). Prema podacima Svetske Zdravstvene Organizacije (WHO) 10-15\% ljudi širom sveta boluje od teške forme parodontopatije (161). Stoga ova bolest predstavlja ozbiljan medicinski, ekonomski i socijalni problem.

Primarni etiološki faktor u nastanku parodontopatije su mikroorganizmi dentalnog plaka, pre svega Porphyromonas gingivalis, Tannerella forsythia, Prevotella intermedia i Aggregatibacter actinomycetemcomitans. Međutim, obim destrukcije parodontalnih tkiva posledica je interakcije mikrobioloških faktora i imunog odgovora domaćina (94).

Polazeći od činjenice da slobodni radikali aktivno učestvuju u oštećenju tkiva tokom mnogih inflamatornih procesa, Chapple i sar. (162) ističu da bi oni mogli imati istu ulogu i u inflamatornom procesu u toku parodontopatije. Naime, tokom inflamacije dolazi do aktivacije polimorfonukleara, monocita i makrofaga i pokreće se respiratorna eksplozija koja se karakteriše povećanom potrošnjom kiseonika, anaerobnom glikolizom, heksozomonofosfatnim šantom i povećanom produkcijom slobodnih radikala (163). Isto tako, tokom parodontopatije kao deo imunog odgovora domaćina na dejstvo parodontopatogena $\mathrm{i}$ njihovih produkata oslobađaju se inflamatorni medijatori koji omogućavaju hemotaksu odbrambenih ćelija na mesto inflamacije. U zaštiti tkiva parodoncijuma od patogenih mikroorganizama prvu liniju odbrane čine polimorfonuklearni leukociti (PML) koji neoksidativnim i oksidativnim mehanizmima neutrališu i uništavaju mikroorganizme. Neoksidativni mehanizmi podrazumevaju dejstvo proteolitičkih enzima koji se oslobađaju iz PML, dok oksidativni mehanizam predstavlja hiperprodukcija kiseoničnih slobodnih radikala. Ovi visoko reaktivni molekuli vrše oksidativnu modifikaciju bakterijskih ćelija ali istovremeno i oksidativnu modifikaciju biomolekula domaćina (4). 


\section{Diskusija}

Prisustvo oksidativnog stresa u usnoj duplji pacijenata sa parodontopatijom je predmet velikog broja istraživanja. Biomarkeri ovog patološkog procesa mogu se analizirati u gingivalnoj tečnosti i pljuvački (101).

Gingivalna tečnost je transudat seruma, ili, češće, inflamatorni eksudat koji se nalazi u gingivalnom sulkusu ili gingivalnom odnosno parodontalnom džepu. Sastojci gingivalne tečnosti potiču od domaćina ali i od mikroorganizama dentalnog plaka. Tako se u njoj nalaze molekuli iz krvi, sastojci koji vode poreklo od tkiva parodoncijuma, kao i ćelija inflamatornog i imunog odgovora infiltrisanih u parodontalna tkiva. Važni sastojci gingivalne tečnosti su pokazatelji inflamacije uključujući enzime i citokine (164).

Sa druge strane, pljuvačka je sekret tri para velikih i velikog broja malih pljuvačnih žlezda koji je u stalnom kontaktu sa tkivima usne duplje i od velike je važnosti za održavanje oralne homeostaze. Zbog intimnog kontakta sa tkivima usne duplje, pljuvačka odražava sva fiziološka i patološka zbivanja u njima, te se u njoj mogu dokazati brojni biohemijski pokazatelji patoloških dešavanja u parodoncijumu $(101,165)$. Osim lokalno proizvedenih supstanci iz usne duplje i gingivalne tečnosti u pljuvački se nalaze i molekuli iz sistemske cirkulacije te bi u nekim slučajevima pljuvačka mogla biti alternativa krvnom serumu i plazmi u pojedinim biohemijskim, farmakološkim i toksikološkim analizama (166-168).

Udeo gingivalne tečnosti u pljuvački pacijenata sa zdravim parodoncijumom iznosi $0,5 \%$ i znatno se povećava kod pacijenata sa inflamacijom gingive (169). Način uzorkovanja pljuvačke može da poremeti ovoj odnos. Istraživanja pokazuju da se u nestimulisanoj i stimulisanoj pljuvački mogu naći različite koncentracije nekih markera. Mastikacija kao najčešće korišćen metod u dobijanju stimulisane pljuvačke, može da dovede do istiskivanja veće količine gingivalne tečnosti iz parodontalnih džepova i na taj način stvori u njoj veštački povećan nivo elemenata iz krvne plazme (126).

Posmatrajući metodologiju dosadašnjih istraživanja, čini se da nema saglasnosti o tome koji bi medijum egzaktnije i bolje pokazao stepen oksidativnog stresa u ustima. Tako Wei i sar. (170) poredeći koncentraciju malondialdehida (MDA)-produkta oksidativnog oštećenja lipida a Dede i sar. (171) poredeći koncentraciju 8-hidroksideoksiguanozina (8OHdG)-produkta oksidativnig oštećenja DNK u gingivalnoj tečnosti i pljuvački osoba sa 
parodontopatijom i zdravih pacijenata, nalaze razliku među ispitanicima samo $u$ gingivalnoj tečnosti. Sa druge strane, Ibrahem i sar. (172) navode da kod pacijenata sa parodontalnim džepovima $<6 \mathrm{~mm}$ nisu detektovali 8-OHdG u gingivalnoj tečnosti, dajući prednost pljuvački u određivanju ovog markera. Akalin i sar. (126) nalaze značajnu korelaciju markera lipidne peroksidacije-MDA u pljuvački i gingivalnoj tečnosti, ističući značaj oba biološka materijala u određivanju ovog markera. Ipak, većina autora se slaže da gingivalna tečnost daje dijagnostičke informacije sa određenih mesta i određenih zuba, što može bitno uticati na rezultate imajući u vidu da je parodontopatija proces koji ne zahvata ravnomerno sve zube pa čak ni sve površine na istom zubu. Sa druge strane, pljuvačka reprezentuje stanje parodoncijuma svih zuba. Isto tako, gingivalna tečnost prilikom uzorkovanja može biti kontaminirana pljuvačkom, krvlju i dentalnim plakom što može dodatno kompromitovati rezultate istraživanja. Imajući u vidu prethodno navedeno, kao i činjenicu da se gingivalna tečnost izliva u pljuvačku, analiza medijatora u ukupnoj pljuvački bi mogla imati prednost u odnosu na gingivalnu tečnost. Analiza pljuvačke je i sa praktičnog stanovišta prihvatljivija jer je prikupljanje pljuvačke jednostavnije u odnosu na gingivalnu tečnost, ne zahteva skupu opremu i posebno obučeno osoblje.

Kao pokazatelj oksidativnog oštećenja DNK, u našem istraživanju je korišćeno određivanje koncentracije 8-OHdG u pljuvački i krvi pacijenata. Naime, slobodni radikali mogu da uzrokuju prekide lanaca, delecije i različite modifikacije nukleozida na molekulu DNK. Postoji preko 100 različitih DNK proizvoda nastalih reakcijom između slobodnih radikala i nukleozida. Neki od njih su: 5,6-dihidrocitozin, 4,6-diamino-5formamidopirimidin, 2,6-diamino-4-hidroksi-5-form-amidopirimidin, 8-hidroksiadenin, 8hidroksiguanin i 8-hidroksideoksiguanozin (133). Jedan od najpouzdanijih i najčešće određivanih biomarkera oksidativnog oštećenja DNK je upravo 8-hidroksideoksiguanozin (8-OHdG). 8-OHdG predstavlja proizvod oksidovane forme 2-deoksiguanozin nukleozida (173) koji se nakon popravke DNK izlučuje u telesne tečnosti. Visoke koncentracije 8OHdG su utvrđene kod naurodegenativnih, malignih i hroničnih inflamatornih oboljenja $(174,175)$. Čak i pri vrlo niskom stepenu oksidativnog oštećenja DNK, izlučuje se urinarni 8-OHdG pa se njegova koncentracija smatra najpouzdanijim biomarkerom endogenog oksidativnog oštećenja DNK (176,177). Neki autori čak smatraju da se 
urinarni 8-OHdG može koristiti kao validan marker rizika u nastanku malignih bolesti (178).

U poslednje vreme sve je veći broj istraživanja koja skreću pažnju na povišene vrednosti salivarnog $8-\mathrm{OHdG}$ kod pacijenata sa parodontopatijom te na moguću ulogu oksidativnog oštećenja DNK u nastanku oboljenja parodoncijuma $(130,179,180)$.

Tako Canakci i sar. (179) nalaze 8-OHdG u koncentraciji od 1,26 ng/ml u pljuvački osoba sa zdravim parodoncijumom a 4,24 ng/ml kod osoba sa parodontopatijom, dok Sezera i sar. (180) izveštavaju o 1,56 ng/ml kod osoba sa zdravim, odnosno 3,13 ng/ml kod osoba sa obolelim parodoncijumom. Značajno povišene vrednosti salivarnog 8OHdG u pljuvački osoba sa parodontopatijom u poređenju sa zdravim objavili su i drugi autori $(171,172,181)$.

I rezultati našeg istraživanja pokazuju da su pacijenati sa parodontopatijom imali statistički značajno više vrednosti salivarnog 8-OHdG u odnosu na pacijente sa zdravim parodoncijumom ( $\mathrm{p}=0,043)$. Tako je $8-\mathrm{OHdG}$ kod naših pacijenata sa parodontopatijom iznosio $0,869 \mathrm{ng} / \mathrm{ml}$ sa rasponom vrednosti od 0,388-2,100 ng/ml, dok je kod zdravih pacijenata iznosio $0,612 \mathrm{ng} / \mathrm{ml}(0,180-1,275 \mathrm{ng} / \mathrm{ml})$.

Vrednosti 8-OHdG u našem istraživanju odgovaraju onima koje su objavili Dede i sar. (171) a koji su koristili sličnu metodologiju i čiji su pacijenti imali približnu destrukciju parodoncijuma kao i naši. 8-OHdG u pljuvački njihovih pacijenata sa parodontopatijom je bio 0,605 ng/ml, dok je kod zdravih pacijenti iznosio 0,550 ng/ml.

Sa druge strane, 8-OHdG u dve prethodno pomenute studije (Canacki 2009. i Sezer 2012.) bio je znatno viši nego u našoj, što može biti posledica manje destrukcije parodoncijuma naših ispitanika. Naime, istraživanja pokazuju da nivo 8-OHdG u pljuvački direktno zavisi od stepena oštećenja parodoncijuma $(130,182,181)$. Tako Badea i sar. (181) izveštavaju da je u njihovoj studiji vrednost 8-OHdG u pljuvački ispitanika sa maksimalnim CPITN bodom 3 bila u rasponu od 5,25-7,50 ng/ml, a kod ispitanika sa maksimalnim CPITN bodom 2 od 3,00-5,00 ng/ml. Ibrahem i sar. kod pacijenata sa parodontalnim džepovima $>6 \mathrm{~mm}$ nalaze 8 -OHdG u koncentraciji od 4,42 ng/ml, kod

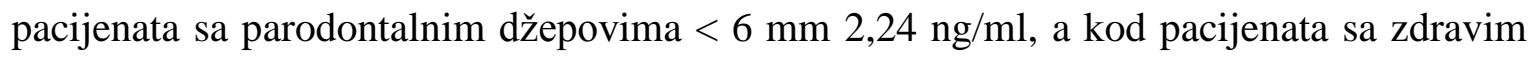




\section{Diskusija}

parodoncijumom 1,56 ng/ml. Oni zaključuju da bi 8-OHdG mogao biti koristan marker u praćenju progresije oboljenja parodoncijuma i proceni rizika za gubitak zuba (172).

Canakci i sar. (183) ispitujući korelaciju kliničkih pokazatelja stanja parodoncijuma sa 8-OHdG kod pacijenata sa parodontopatijom, dobijaju pozitivnu korelaciju dubine sondiranja (DS) i nivoa pripojnog epitela (NPE) i salivarnog 8-OHdG. Ovaj rezultat autori povezuju sa dužinom trajanja i težinom oboljenja i objašnjavaju da u toku parodontopatije dolazi do dugotrajne stimulacije proinflamatornih citokina, pre svega TNF $\alpha$, koji može da dovede do hiperprodukcije reaktivnih kiseoničnih vrsta od strane PML i mitohondrija. I Sezer i sar. (180) poredeći nivo 8-OHdG kod pacijenata sa parodontopatijom, gingivitisom i pacijenata sa zdravim parodoncijumom, nalaze značajno više vrednosti ovog markera kod pacijenata sa parodontopatijom u odnosu na ostale dve grupe pacijenata. Činjenicu da se vrednost $8-\mathrm{OHdG}$ nije razlikovala kod pacijenata sa gingivitisom i zdravih pacijenata, objašnjavaju time da sama inflamacija nije dovoljan faktor za povećanje vrednosti ovog markera u salivi. Rezultati dobijeni u našem istraživanju takođe pokazuju da nivo $8-\mathrm{OHdG}$ nije bio povezan sa stepenom inflamacije gingive već sa stepenom destrukcije dubljih parodontalnih tkiva. Tako su njegove vrednosti kod pacijenata sa izraženom inflamacijom $(0,889 \mathrm{ng} / \mathrm{ml})$ i umerenom inflamacijom gingive $(0,852 \mathrm{ng} / \mathrm{ml})$ bile gotovo iste $(\mathrm{p}=0,839)$. Međutim, poredeći njegove vrednosti kod pacijenata sa većom dubinom sondiranja $(0,967 \mathrm{ng} / \mathrm{ml})$ i onih sa manjom dubinom sondiranja $(0,700 \mathrm{ng} / \mathrm{ml})$ beleži se razlika koja je blizu statističke značajnosti ( $\mathrm{p}=0,057)$. Isto tako, analizirajući 8-OHdG u odnosu na nivo pripojnog epitela, dobili smo statistički značajno veću vrednost 8-OHdG $(\mathrm{p}=0,042)$ kod pacijenata sa $\mathrm{NPE} \geq 3 \mathrm{~mm}$ u odnosu na pacijente sa $\mathrm{NPE}<3 \mathrm{~mm}$. I Sezer i sar. u prethodno navedenoj studiji (180) takođe izveštavaju o značajno višim vrednostima 8-OHdG kod pacijenata sa $\mathrm{NPE} \geq 3 \mathrm{~mm}$ u odnosu one sa NPE $<3 \mathrm{~mm}$. Interesantno je da se vrednost ovog markera kod njihovih pacijenata sa parodontopatijom i NPE<3 mm nije razlikovala od vrednosti kod pacijenata sa gingivitisom i sa zdravim parodoncijumom, što je još jedna potvrda da na vrednost 8-OHdG u pljuvački pacijenata sa parodontopatijom najviše utiče stepen destrukcije dubljih parodontalnih tkiva. 
Pored oksidativnog oštećenja DNK i oksidativno oštećenje lipida nastaje toksičnim delovanjem slobodnih radikala. Naime, polinezasićene masne kiseline fosfolipidnog sloja ćelijskih membrane predstavljaju glavne ciljne molekule reaktivnih kiseoničnih vrsta. Najreaktivniji slobodni radikal kiseonika $\mathrm{OH}$ • započinje proces lipidne peroksidacije koji se zatim nastavlja nizom lančanih reakcija do formiranja lipidnih hidroperoksida i aldehida. Akumulacija hidroperoksida u plazma membrani i membranama organela dovodi do promene fluidnosti membrane i tako utiče na aktivnost transmembranskih enzima, transportera, receptora i drugih membranskih proteina. Krajnji rezultat lipidne peroksidacije je promena propustljivosti membrane, što dovodi do narušavanja ćelijskog metabolizma i homeostaze, kao i ćelijske smrti (184). Najpoznatiji toksični aldehidni produkti lipidne peroksidacije su malondialdehid (MDA) i 4-hidroksinonenal (HNE) (3, $185)$.

Brojni podaci ukazuju da nivo MDA u fiziološkim tečnostima može da bude pouzdan indikator obima oksidativnog oštećenja ćelija u organizmu (186). Naime, utvrđena je visoka koncentracija serumskog MDA kod pacijenata sa hroničnim hepatitisom C (187) i HIV pozitivnih pacijenata (188). Nadalje, Al-Rawi i sar. (189) izveštavaju o značajno višim vrednostima MDA u pljuvački i krvi pacijenata sa dijabetesom u odnosu na ispitanike koji ne boluju od dijabetesa. Visoka koncentracija MDA utvrđena je i kod nekih malignih oboljenja (190).

Isto tako, utvrđeno je da HNE dovodi do inhibicije antioksidativnih enzima glutation peroksidaze, glutation S-tranferaze, denaturacije proteina i oštetenja DNK (191,192). Povećana koncentracija HNE zabeležena je kod ateroskleroze, neurodegenerativnih bolesti, dijabetesa, autoimunih i malignih oboljenja (193-196).

Osim određivanja koncentracije MDA i HNE, stepen lipidne peroksidacije može se pratiti i određivanjem reaktivnih metabolita tiobarbiturne kiseline (TBARS). Povišena vrednost TBARS-a zabeležena je kod HIV pozitivnih pacijenata (197), kod pacijenata sa dijabetesom, posebno kod onih sa vaskularnim komplikacijama (198), kod malignih oboljenja (199), pušača (200) i nakon fizičke aktivnosti (201).

Kao pokazatelj stepena lipidne peroksidacije i oksidativnog oštećenja lipida kod naših pacijenata korišćeno je određivanje koncentracije malondialdehida (MDA). 
Ranije se smatralo da na nivo lipidne peroksidacije u pljuvački najviše utiče nivo ovog procesa u krvi, dok je danas utvrđeno da lokalno proizveden oksidativni stres ima važniju ulogu. Istraživanja pokazuju da se u toku parodontopatije oslobađaju produkti lipidne peroksidacije, kao što je MDA, koji učestvuju u daljem toku inflamacije i destrukcije parodontalnih tkiva $(126,141,179,202,203)$. Tako npr. Sheikhi i sar. (202) su ispitujući intraćelijsku produkciju i ekstraćelijsko oslobađanje reaktivnih oblika kiseonika iz PML stimulisanih Fusobacterium nucleatum-om pokazali da u toku prvog sata postoji intraćelijska produkcija reaktivnih oblika kiseonika, da bi zatim u toku naredna 4 sata došlo do ekstraćelijskog oslobađanja produkata lipidne peroksidacije u velikom procentu. Triana i sar. (204) su ispitivali koncentraciju MDA u gingivi, dubinu sondiranja i nivo resorpcije alveolarne kosti na psima kojima je na jednoj polovini vilice eksperimentalnim putem izazvana parodontopatija, a druga polovina vilice je služila kao kontrolna. Vrednosti ovih parametara bile su statistički značajno veće na polovini vilice sa parodontopatijom u odnosu na kontrolnu polovinu.

Osim kod pacijenata sa parodontopatijom, utvrđeno je da su vrednosti MDA povišene i kod drugih oboljenja u usnoj duplji. Tako Marton i sar. (205) izveštavaju o višim vrednostima ovog markera u tkivu hroničnog apikalnog parodontitisa u odnosu na zdravo tkivo gingive istog ispitanika, dok Saral i sar. (206) beleže povišene vrednosti MDA kod pacijenata sa rekurentnim aftoznim ulceracijama.

I rezultati našeg istraživanja ukazuju na porast nivoa MDA u pljuvački kod postojanja inflamatornog procesa u parodoncijumu. Naime, vrednost ovog markera kod pacijenata sa parodontopatijom na početku istraživanja iznosila je 2,99 pmol/ $\mu 1$, a kod zdravih ispitanika $1,33 \mathrm{pmol} / \mu 1$, što predstavlja statistički značajnu razliku. Koncentracija MDA u našem istraživanju izražena je u pmol/ $\mu 1$, ali imajući u vidu da je korišćena koncentracija uzorka sadržala $10 \mu \mathrm{g} / \mathrm{ml}$ proteina iz uzorka, dobijeni rezultati se mogu identifikovati kao nmol/ml. Ovo je važno zbog poređenja rezultata sa drugim studijama jer su one koncentraciju MDA uglavnom izražavale u nmol/ml.

I drugi autori izveštavaju o značajno višim vrednostima markera lipidne peroksidacije u pljuvački pacijenata sa parodontopatijom u odnosu na zdrave ispitanike. Tako Canakci i sar. (179) beleže MDA u koncentraciji od 7,35 nmol/ml u pljuvački osoba 
sa parodontopatijom a 5,41 nmol/ml kod osoba sa zdravim parodoncijumom. Autori ove rezultate dovode $\mathrm{u}$ vezu sa padom antioksidativnog kapaciteta kod pacijenata sa parodontopatijom. Više vrednosti MDA u njihovoj studiji možemo objasniti razlikom u metodologiji i jačim stepenom destrukcije potpornog aparata zuba u odnosu na naše pacijente. Naime, ova grupa autora koristila je stimulisanu pljuvačku, dok je u našem istraživanju korišćena nestimulisana pljuvačka. Kao što smo ranije napomenuli, u toku uzorkovanja stimulisane pljuvačke izliva se veća količna gingivalne tečnosti u pljuvačku što može značajno da poveća vrednost ispitivanih markera. Gutteridge (207) ističe da se na osnovu nivoa markera lipidne peroksidacije može proceniti stepen oštećenja parodoncijuma. Na to upućuju i nalazi Khalili i sar. (208) koji izveštavaju ne samo o višim vrednostima MDA kod pacijenata sa parodontopatijom u odnosu na zdrave, nego i o razlici u vrednostima ovog markera kod osoba sa blagom, umerenom i uznapredovalom formom bolesti. Nadalje, autori beleže značajne korelacije MDA sa indeksom krvarenja, dubinom sondiranja i nivoom pripojnog epitela, zaključivši da se MDA može koristiti kao pokazatelj kliničkog statusa pacijenata sa parodontopatijom. Slične rezultate beleže i Akalin i sar. (126). Naime, oni izveštavaju o značajno višim vrednostima MDA u pljuvački i gingivalnoj tečnosti pacijenata sa parodontopatijom ali i o pozitivnoj korelaciji ovog markera sa svim ispitivanim kliničkim parametrima (PI, GI, IK, DS, NPE). Sa druge strane, poredeći kliničke parametre parodontopatije sa nivoom MDA u pljuvački, Daković (209) nalazi vezu ovog markera sa stepenom inflamacije ali ne i sa dubinom parodontalnih džepova. Kako je tok parodontopatije cikličan i periodi remisije se smenjuju sa periodima egzacerbacije u toku koje dolazi do aktiviranja svih znakova inflamacije, autor zaključuje da bi visok nivo MDA kod pacijenata sa parodontopatijom mogao biti znak aktivnosti procesa $u$ parodoncijumu. Rezultati našeg istraživanja su u skladu sa nalazima ovog autora. Na vrednost MDA u pljuvački naših pacijenata najviše je uticala upravo inflamacija gingive. Naime, pacijenti sa izraženom inflamacijom gingive su imali statistički značajno više vrednosti MDA $(3,616 \mathrm{pmol} / \mu \mathrm{l}) \mathrm{u}$ odnosu na pacijente sa umerenom inflamacijom $(2,419 \mathrm{pmol} / \mu \mathrm{l})(\mathrm{p}=0,045)$. Uticaj dubine sondiranja a naročito nivoa pripojnog epitela nije bio statistički značajan. Iako kod pacijenata sa većom dubinom sondiranja MDA beleži više vrednosti u odnosu na grupu sa manjom dubinom 


\section{Diskusija}

sondiranja ( $\mathrm{p}=0,203)$, smatramo da je i ovaj nalaz zapravo posledica inflamacije. Naime, vrednost dubine sondiranja sa jedne strane zavisi od uvećanja gingive usled inflamacije a sa druge od destrukcije potpornih zubnih tkiva. Kako nivo pripojnog epitela, kao pouzdan parameter destruktivnog procesa nije imao uticaj $(\mathrm{p}=0,512)$ na vrednost MDA, mišljenja smo da je kod pacijenata sa većom dubinom sondiranja upravo inflamatorna komponenta uticala na više vrednosti ovog markera.

Kao odgovor jedinke na oksidativno oštećenje ćelija uspostavljen je specifičan odbrambeni sistem od štetnog delovanja slobodnih radikala, koji je označen kao antioksidativni sistem. Antioksidanti se definišu kao supstance koje, u malim koncetracijama, imaju sposobnost da mehanizmom kompeticije odlože ili inhibišu oksidaciju drugih materija. Prema prirodi i načinu delovanja antioksidanti se mogu podeliti na: enzimske (superoksid-dizmutaza, katalaza, glutation reduktaza, glutation Stransferaza i dr.) i neenzimske (glutation, vitamini A, C i E, albumini, ceruloplazmin, transferin, bilirubin, mokraćna kiselina i dr.)

Veoma često korišćen parameter antioksidativnog kapaciteta je superoksiddismutaza-SOD. Međutim povišene ili snižene vrednosti SOD se u različitim istraživanjima različito pa čak i potpuno suprotno tumače. Tako pojedini autori visoke vrednosti ovog enzima vide kao znak dobre antioksidativne odbrane, dok nizak SOD smatraju znakom smanjenog antioksidativnog kapaciteta i oksidativnog stresa $(118,119)$. Naime, niže vrednosti aktivnosti SOD, prema Selvem i sar. (118) znače i manju sposobnost neutralizacije superoksid anjona koji je onda slobodan da reaguje sa vodonikom i stvara vodonik peroksid ili sa vodonik peroksidom, kada nastaje hidroksil radikal. Nezaustavljeni superoksid tada pokreće lanac stvaranja reaktivnih kiseoničnih vrsta sa svim neželjenim efektima koji slede. Stoga, veća aktivnost SOD znači i bolju antioksidativnu zaštitu. Visoka aktivnost SOD se, međutim, od strane drugih autora tumači upravo suprotno, odnosno kao znak oksidativnog stresa (210-212). U istraživanju Fulle i sar. (210) i Surapanemi i sar. (211) pored visokih vrednosti SOD nađene su i visoke vrednosti drugih antioksidativnih enzima, kao i visoke vrednosti markera 8-OHdG i MDA što oni tumače kao znak povećanog oksidativnog oštećenja. Isto tako, Igaru i sar. (213) izveštavaju o četiri puta većoj koncentrciju SOD u sinovijalnoj tečnosti pacijenata sa 


\section{Diskusija}

reumatoidnim artritisom, dok Kimura i sar. (214) nalaze čvrstu vezu između koncentracije SOD i težine mikro i makrovaskularnih komplikacija kod pacijenata sa dijabetesom i zaključuju da bi serumski SOD mogao biti marker vaskularnog oštećenja.

$\mathrm{U}$ poslednje vreme veliki broj istraživanja se bavi ispitivanjem SOD kod pacijenata sa parodontopatijom uz takođe često različite a ne retko i potpuno kontradiktorne rezultate. Najbolji primer za to predstavljaju istraživanja Akalina i saradnika (215) koji 2005. godine izveštavaju o višim vrednosima SOD kod pacijenata sa parodontopatijom, da bi nekoliko godina kasnije objavili niže vrednosti kod ovih

pacijenata u odnosu na zdrave ispitanike (216). Različite rezultate autori objašnjavaju razlikom u metodologiji, načinu čuvanja uzoraka, broju pacijenata, aktivnosti bolesti i jedinicama u kojima je izražavana koncentracija SOD. Isto tako Ellis i sar. (217) nalaze značajno i progresivno smanjenje aktivnosti SOD sa povećanjem dubine parodontalnih džepova, dok Canacki i sar. (218) nalaze smanjenu aktivnost SOD u gingivalnoj tečnosti trudnica obolelih od parodontopatije. Nasuprot tome Novaković i sar. beleže više vrednosti SOD kod pacijenata sa destrukcijom parodoncijuma u odnosu na zdrave ispitanike (219). Wei i sar. (170) ispitujući aktivnost SOD u pljuvački i gingivalnoj tečnosti kod 48 osoba obolelih od hronične parodontopatije i 35 osoba sa klinički zdravim parodoncijumom, u oba ispitivana supstrata dobijaju značajno više vrednosti u grupi pacijenata sa parodontopatijom (216,4 U/mg protein, u odnosu na 174,9 U/mg protein).

I rezultati našeg istraživanja pokazuju da su vrednosti SOD izražene bilo kao koncentracija ili kao procenat aktivnosti u pljuvački pacijenata sa parodontopatijom bile statistički značajno više nego kod pacijenata sa zdravim parodoncijumom. Koncentracija SOD u pljuvački pacijenata sa parodontopatijom iznosila je $0,156 \mathrm{U} / \mu 1$, odnosno 0,022 $\mathrm{U} / \mu 1 \mathrm{kod}$ zdravih ispitanika, dok je njegova aktivnost bila 14,89\% i 7,58\%.

Obzirom na ovakve rezultate bliži smo zaključku da povećanje vrednosti SOD predstavlja važan mehanizam odbrane u toku inflamacije u parodoncijumu. Naime, tokom inflamacije bakterijski lipopolisaharidi stimulišu oslobađanje $\mathrm{O}_{2}$ iz tkivnih fibroblasta $\mathrm{i}$ polimorfonuklearnih leukocita (220). Ova povećana produkcija $\mathrm{O}_{2}$ dovodi do povećanog stvaranja i aktivnosti SOD u parodoncijumu kako bi se uspostavio balans između oksidativnog stresa i antioksidativne zaštite (221). 
Poredeći koncentracije SOD u tkivu gingive i gingivalnoj tečnosti, Akalin i sar. nalaze mnogo veće vrednosti ovog markera u tkivu, ističući da su ćelije i tkivo pogodni medijumi za ispitivanje koncentracije SOD za razliku od ekstracelularnih tečnosti u kojima je njegova koncentracija izuzetno niska (126). Naše istraživanje, međutim, pokazuje da je SOD bio detektabilan u pljuvački svih pacijenata i da se pljuvačka kao jednostavnija metoda može koristiti za utvrđivanje njegove koncentracije kako kod pacijenata sa parodontopatijom, tako i kod zdravih ispitanika.

Analizirajući uticaj pojedinih parodontoloških parametara na koncentraciju i aktivnost SOD u pljuvački pacijenata sa parodontopatijom, konstatovali smo da su i inflamacija gingive i destrukcija dubljih parodontalnih tkiva najverovatnije doprineli njegovoj višoj vrednosti kod ovih pacijenata. Naime, SOD je kod pacijenata sa izraženom inflamacijom gingive bio znatno viši $(0,297 \mathrm{U} / \mu \mathrm{l}) \mathrm{u}$ odnosu na pacijente sa umerenom inflamacijom $(0,033 \mathrm{U} / \mu)$. Ovaj marker je bio viši i kod pacijenata sa većom dubinom sondiranja kao i višim nivoom pripojnog epitela ali bez statističke značajnosti. Na pozitivnu korelaciju SOD i gingivalne inflamacije ukazuju i Novaković i sar. (219), objašnjavajući to povećanom potrebom za SOD-om u cilju zaštite gingive u toku inflamatornih procesa.

Jedan od ciljeva našeg istraživanja bio je i da se utvrdi da li bi kauzalna terapija parodontopatije mogla uticati na stepen oksidativnog stresa. Naime, cilj kauzalne faze terapije je eliminacija inflamacije u parodoncijumu i podizanje biološkog potencijala parodontalnih tkiva pa bi se moglo očekivati da bi ovi procesi, osim pozitivnih kliničkih efekata, mogli biti praćeni i smanjenjem oksidativnog stresa.

Dobijeni rezultati su pokazali da su lokalne terapijske mere, uz obuku i motivaciju pacijenata za redovno održavanje oralne higijene, dovele do značajnog kliničkog poboljšanja stanja parodoncijuma. Tako je PI sa 1,40, koliko je iznosio na početku istraživanja, nakon terapije smanjen na 0,35 . Smanjenje plak indeksa i poboljšanje oralne higijene pacijenata dovelo je i do značajnog smanjenja vrednosti gingivalnog indeksa $\mathrm{i}$ indeksa krvarenja. GI je tako smanjen sa 1,79 na 0,25, dok je IK smanjen sa 1,57 na 0,71. Stišavanje inflamatornih procesa u obolelom parodoncijumu uticalo je i na smanjenje dubine sondiranja sa početnih $3,14 \mathrm{~mm}$ na $2,59 \mathrm{~mm}$ nakon terapije. Ovakvi rezultati su 
očekivani i ne razlikuju se od rezultata sličnih istraživanja. Tako Feres i saradnici beleže smanjenje dubine sondiranja sa $3,7 \mathrm{~mm}$ na $3,1 \mathrm{~mm}$ (222), dok Swierkot i sar. izveštavaju o smanjenju dubine sondiranja sa 3,20 mm na 2,58 $\mathrm{mm}$ (223). Rezultati dalje pokazuju i smanjenje vrednosti nivoa pripojnog epitela za $0,51 \mathrm{~mm}$ nakon terapije. I gore pomenute studije beleže slične rezultate. Tako je kod Feresa i sar. smanjenje vrednosti nivoa pripojnog epitela iznosilo 0,40 mm (222), a kod Swierkot i sar. 0,49 mm (223).

Rezultati istraživanja dalje pokazuju da je preduzeta terapija pored poboljšanja parodontološkog statusa pacijenata dovela i do smanjenja lokalnog oksidativnog stresa što pokazuju značajno snižene vrednosti sva tri ispitivana markera u pljuvačku. Tri meseca posle terapije zabeleženo je statistički značajno smanjenje salivarnog 8-OHdG. Vrednost ovog markera je kod pacijenata sa parodontopatijom na početku istraživanja iznosila 0,869 $\mathrm{ng} / \mathrm{ml}$ da bi nakon terapije pala na $0,618 \mathrm{ng} / \mathrm{ml}$ i time se gotovo izjednačila sa vrednosti kod zdravih pacijenata $(0,612 \mathrm{ng} / \mathrm{ml})$. Statistički značajno smanjenje vrednosti $8-\mathrm{OHdG}$ dobijaju i Sugano i sar. (182) i Rai i sar. (134) Naši rezultati odgovaraju i rezultatima Dede i sar. (171) koji takođe izveštavaju o smanjenju vrednosti 8-OHdG nakon kauzalne terapije na vrednost ovog markera kod zdravih pacijenata, mada to smanjenje u njihovoj studiji nije bilo statistički značajno. Takane i sar. (130) navode da su zubi sa lošom prognozom glavni izvor 8-OHdG u pljuvački i da kauzalna terapija parodontopatije dovodi do statistički značajnog smanjenja nivoa 8-OHdG kod ispitanika kod kojih su zubi u terminalnoj fazi parodontopatije ekstrahovani. Kod ispitanika koji nisu imali zube u terminalnoj fazi, smanjenje 8-OHdG u pljuvački posle parodontološke terapije nije bilo statistički značajno. Slične rezultate beleži i Ibrahem (172). Rezultati njegovog istraživanja pokazuju značajno smanjenje salivarnog 8-OHdG nakon terapije u grupi pacijenata sa parodontalnim džepovima $>6 \mathrm{~mm}$, uz istovremeno smanjenje njihove dubine. Sa druge strane, smanjenje dubine parodontalnih džepova $<6 \mathrm{~mm}$ nakon terapije nije pratilo i značajno smanjenje 8-OHdG u ovoj grupi pacijenata.

U našem istraživanju parodontoploška terapija je dovela do statistički značajnog smanjenja 8-OHdG kako kod pacijenata sa izraženom i umerenom inflamacijom gingive, tako i kod pacijenata sa $\mathrm{NPE} \geq 3 \mathrm{~mm}$ i $\mathrm{NPE}<3 \mathrm{~mm}$. Međutim na redukciju salivarnog 8OHdG nakon terapije i u našoj kao i u prethodno navedenoj studiji najviše je uticalo 
smanjenje dubine sondiranja. Naime, iako je i u grupi pacijenata sa većom i u grupi sa manjom dubinom sondiranja došlo do statistički značajnog smanjenja 8-OHdG, razlika u vrednostima ovog markera pre i posle terapije u grupi sa većom dubinom sondiranja bila je dva puta veća od razlike u grupi sa manjom dubinom sondiranja.

I koncentracija MDA u pljuvački naših pacijenata statistički je značajno smanjena posle primenjene terapije $(2,14 \mathrm{pmol} / \mu \mathrm{l}) \mathrm{u}$ odnosu na vrednost pre terapije $(2,99 \mathrm{pmol} / \mu \mathrm{l})$. No, i pored smanjenja, koncentracija MDA posle terapije je i dalje bila viša kod pacijenata sa parodontopatijom nego kod zdravih ispitanika $(1,33 \mathrm{pmol} / \mu \mathrm{l})$. Daković takođe izveštava o smanjenju MDA u pljuvački pacijenata sa parodontopatijom nakon terapije za $58 \%$ i zaključuje da se uporedo sa eliminacijom gingivalne inflamacije eliminišu i produkti oksidativnih oštećenja ćelija (209). Rezultati našeg istraživanja su u saglasnosti i sa rezultatima istraživanja Tsai i sar. (127) koji isto tako izveštavaju o smanjenju markera lipidne peroksidacije u pljuvački pacijenata sa parodontopatijom nakon terapije $(0,63 \mu \mathrm{M}$ pre terapije, $0,41 \mu \mathrm{M}$ posle terapije). Nasuprot ovim rezultatima Wei i sar. (170) beleže značajno smanjenje vrednosti MDA u gingivalnoj tečnosti, dok se vrednosti u pljuvački posle terapije nisu razlikovale od onih sa početka istraživanja niti su se razlikovale od vrednosti kod zdravih pacijenata. Autori zaključuju da se lipidna peroksidacija u gingivalnoj tečnosti kvalitativno i kvantitativno razlikuje od nivoa u serumu, plazmi ili pljuvački.

Analizirajući dobijene vrednosti MDA nakon terapije u pljuvački naših pacijenata u zavisnosti od inflamacije gingive, dubine sondiranja i nivoa pripojnog epitela, možemo zaključiti da je na redukciju MDA u našem istraživanju najviše uticalo smanjenje dubine sondiranja. Naime, u grupi pacijenata sa većom dubinom sondiranja razlika u vrednostima pre i posle terapije iznosila je 1,058 pmol/ $\mu$ l dok je u grupi sa manjom dubinom sondiranja ova razlika bila gotovo upola manja $(0,532 \mathrm{pmol} / \mu \mathrm{l}, \mathrm{p}=0,084)$.

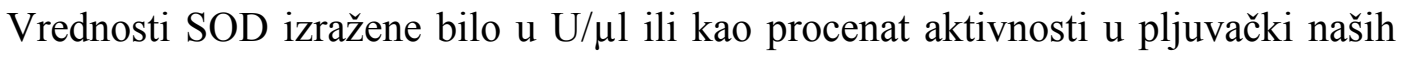
pacijenata nakon terapije beleže pad koji je bio na granici statističke značajnosti (SOD$\mathrm{p}=0,052, \%$ SOD-p=0,053). Naime, vrednost SOD pre terapije je iznosila $0,156 \mathrm{U} / \mu \mathrm{l}$ dok je nakon terapije bila $0,052 \mathrm{U} / \mu 1$. Aktivnost SOD je na početku našeg istraživanja iznosila 
$14,89 \%$ da bi nakon terapije pala na $11,84 \%$. Slično našim rezultatima, i Wei i sar. (170) izveštavaju o značajnom smanjenju vrednosti SOD posle terapije (169,8 U/mg protein) u odnosu na vrednost sa početka istraživanja (216,4 U/mg protein). Novaković i sar. (219) takođe beleže statistički značajno niže vrednosti SOD posle tarapije kod pacijenata sa parodontopatijom. Nasuprot njima, Karim i sar. (121) dobijaju veće vrednosti SOD nakon parodontološke terapije, dok Kim i sar. (224) izveštavaju o smanjenju vrednosti SOD mesec dana nakon terapije i porastu njegove vrednosti nakon tri meseca. Povećanje SOD nakon terapije ovi autori objašnjavaju eliminacijom inflamacije parodoncijuma i smanjenjem oksidativnog stresa kao i posledičnim obnavljanjem i povećanjem antioksidativnog kapaciteta.

Naše je, pak, mišljenje da parodontopatija kao hronično oboljenje koje traje godinama dovodi do adaptacije organizma na stalnu iritaciju slobodnim radikalima i kompenzatornog povećanja aktivnost najvažnijeg antioksidativnog enzima. Viša početna vrednost SOD kod ispitanika sa parodontopatijom zapravo je kompenzacija usled stalnog prisustva reaktivnih kiseoničnih vrsta $\mathrm{i}$ inflamacije, te nakon primene terapije zajedno sa smanjenjem inflamacije dolazi i do normalizacije aktivnosti ovog enzima. Na ovo upućuju i nalazi Sukhtankar i sar. (225) koji ispitujući uticaj parodontološke terapije na gingivalni SOD, izveštavaju o njegovom značajnom smanjenju nakon terapije i izjednačavanju sa vrednosti kod zdravih pacijenata. Autori dobijene rezultate povezuju sa signifikantnom redukcijom inflamacije gingive nakon sprovedene terapije.

Rezutati našeg istraživanja dalje pokazuju da je koncentracija SOD kao i njegova aktivnost nakon trapije statistički značajno smanjena u grupi pacijenata sa izraženom inflamacijom gingive, većom dubinom sondiranja i u grupi pacijenata sa $\mathrm{NPE} \geq 3 \mathrm{~mm}$. Vrednosti ovog markera su u grupi pacijenata sa umerenom inflamacijom, manjom dubinom sondiranja i NPE $<3 \mathrm{~mm}$ nakon terapije ostale gotovo nepromenjene. Ovaj nalaz tumačimo kao još jednu potvrdu prethodno iznete tvrdnje da se SOD progresivno povećava sa inflamacijom i destrukcijom parodoncijuma, te da se njegove vrednosti smanjuju sa smanjenjem i eliminacijom inflamacije.

Osim što sistemske bolesti utiču na stanje parodoncijuma, u poslednje vreme sve češće se govori i o mogućem uticaju parodontopatije na sistemsko zdravlje. Iako tačan 
mehanizam veze parodontopatije i sistemskih oboljenja još uvek nije potpuno razjašnjen, smatra se da parodontopatija može povećati skonost ka sistemskim oboljenjima tranzitornom bakterijemijom iz parodontalnih džepova i ulaskom mikroorganizama i njihovih produkata u krvotok. Naime, subgingivalni biofilm predstavlja stalni izvor Gramnegativnih bakterija i njihovih produkata, pre svega lipopolisaharida, koji imaju pristup dubljim parodontalnim tkivima i sistemskoj cirkulaciji. Jedina barijera između biofilma i vezivnog tkiva je epitel parodontalnog džepa. Plaže tankog, često ulcerisanog epitela omogućavaju prodor bakterija u vezivno tkivo i krvne sudove. Smatra se da ukupna površina epitela parodontalnih džepova koja je u direktnom kontaktu sa subgingivalnim biofilmom kod pacijenata sa srednjim i teškim oblicima bolesti, može biti veličine dlana, a u slučajevima uznapredovale bolesti i mnogo veća (226).

Sa druge strane, proinflamatorni citokini, TNF- $\alpha$, IL-1 $\beta$, INF- $\gamma$, kao i PGE2 nalaze se $u$ visokim koncentracijama u tkivu zahvaćenom parodontopatijom. Na taj način oboleo parodoncijum može služiti kao rezervoar citokina i prostaglandina koji ulaze u cirkulaciju gde pokreću i održavaju sistemsku rekaciju. Istraživanja pokazuju da je kod pacijenata sa parodontopatijom zabeležen povišen nivo cirkulatornih proinflamatornih medijatora kao što su: TNF- $\alpha$, IL-1 $\beta$ i IL-6 koji u naletima oštećuju endotel krvnih sudova (227-231). Cirkulatorni citokini indukuju sistemski inflamatorni odgovor i sintezu C reaktivnog proteina (CRP) koji se smatra najznačajnijim faktorom rizika za kardiovaskularne bolesti (232,233). Procenjuje se da oboleli od parodontopatije imaju 1,2 puta veći rizik za nastanak kardiovaskularnih bolesti i 2,9 puta veći rizik za nastanak infarkta miokarda (234). Danas se zna da je ateroskleroza, koja predhodi ishemijskim događajima na srcu i mozgu, inflamatorno oboljenje na koje utiče hronična sistemska inflamacija (235). Osim toga, sistemska inflamacija je povezana i sa pojavom dijabetesa melitusa tip 2 a različiti inflamatorni medijatori, kao što su TNF $\alpha$, IL-6 i CRP, mogu indukovati insulinsku rezistenciju i pogoršanje stepena metaboličke kontrole šećerne bolesti (236). Tako Taylor i sar. (237) izveštavaju da pacijenti sa dijabetesom i uznapredovalom parodontopatijom imaju čak 6 puta veću verovatnoću za pogoršanje metaboličke kontrole u odnosu na ispitanike sa manjim oštećenjem parodoncijuma. Parodontopatija se dovodi u vezu i sa povećanim rizikom za pojavu komplikacija dijabetesa pre svega kardiovaskularnih i 
cerebrovaskularnih (238), te neki autori ističu da bi terapija parodontopatije mogla imati ne samo pozitivan lokalni, već i pozitivan sistemski efekat (239-241). Nadalje, studije pokazuju da bi parodontopatija mogla biti faktor rizika u nastanku prevremenog porođaja (149). Prevremeni porođaj može biti iniciran proinflamatornim molekulima IL-6, IL-8, IL$1 \beta$ i TNFa koji izazivaju kontrakcije materice (242). Pretpostavlja se da bi parodontopatogeni hematogenim putem mogli doći do placente i podstaći je na lokalno stvaranje proinflamatornih molekula. Tome u prilog idu i istraživanja koja pokazuju da se iz amnionske tečnosti i placente žena koje su prevremeno rodile može izolovati Porphyromonas gingivalis $(243,244)$. Parodontopatija se takođe povezuje i sa nastankom respiratornih infekcija (245) i reumatoidnog artritisa (246).

No, pitanje da li zaista parodontopatije mogu povećati sklonost ka nastanku opštih oboljenja i dalje ostaje otvoreno. Naime, većina ovih bolesti dele zajedničke faktore rizika te je uzročnu povezanost veoma teško utvrditi. Međutim, čak i nagoveštaj činjenice da bi parodontopatije mogle uticati na sistemsko zdravlje čine dalja istraživanja na ovom planu neophodnim.

Osim infektivne i inflamatorne komponente parodontalnih lezija u poslednje vreme sve više pažnje se posvećuje i oksidativnom stresu kao mogućoj vezi parodontopatije i sistemskih oboljenja. Naime, reaktivni oblici kiseonika proizvedeni tokom parodontopatije mogu da difunduju u krvotok i da dovedu do oksidacije biomolekula krvi stvarajući cirkulatorni oksidativni stres. Cirkulatorni oksidativni stres prouzrokovan hroničnim oboljenjima kao što je parodontopatija može postepeno oštetiti udaljena tkiva i organe i biti štetan za sistemsko zdravlje (135). U prilog ovome idu i istraživanja koja su pokazala da je parodontopatija u negativnoj korelaciji sa sistemskim ukupnim antioksidativnim kapacitetom (TAOC). Naime kod pacijenata sa parodontopatijom je utvrđen nizak nivo gingivalnog ali i sistemskog TAOC u odnosu na zdrave ispitanike (99). Brock i sar. izveštavaju da bi smanjen antioksidativni kapacitet u krvi pacijenata sa parodontopatijom mogao biti faktor rizika za nastanak kardiovaskularnih oboljenja. Autor objašnjava da bi smanjen sistemski antioksidativni kapacitet mogao za posledicu imati dugotrajno oslobađanje manjih količina reaktivnih kiseoničnih vrsta iz perifernih neutrofila stimulisanih parodontopatogenima, koji mogu dovesti do razvoja aterosklerotskih 
promena. I Ekuni i sar. (139) ukazuju da bi oksidativni stres nastao kao posledica parodontopatije mogao imati značajnu ulogu u progresiji ateroskleroze obzirom da je parodontopatija kod eksperimentalnih miševa bila praćena povećanjem markera peroksidacije lipida u krvi, kao i akumulacijom lipida u aorti. Istraživanje Tamaki i sar. (247) pokazuje da pacijenti sa parodontopatijom imaju viši nivo oksidisanog LDL u krvi u odnosu na zdrave pacijente, kao $i$ da se njegov nivo značajno smanjuje nakon parodontološke terapije. Obzirom da je oksidisani LDL faktor rizika u nastanku kardiovaskularnih bolesti (248), autori zaključuju da bi parodontološki tretman mogao imati značajnu ulogu u prevenciji ovih oboljenja (247). Tomofuji i sar. ističu vezu parodontopatije i oksidativnog oštećenja jetre kod laboratorijskih životinja $(136,249)$. Ova grupa istraživača izveštava da eksperimentalno izazvana parodontopatija kod miševa dovodi do povećanja nivoa serumskog vodonik peroksida i oksidativnog oštećenja DNK jetre (249), kao i do smanjenja odnosa oksidovanog i redukovanog glutationa (GSSG/GSH) kao pokazatelja detoksikacionog kapaciteta ćelija uz povećan nivo heksanoil-lizina, markera lipidne peroksidacije (136). Stoga autori zaključuju da oksidativni stres izazvan parodontopatijom može da pokrene i pogorša oštećenje jetre.

Obzirom na rezultate pomenutih studija, jedan od ciljeva ovog istraživanja bio je i određivanje stepena oksidativnog stresa u krvi pacijenta sa parodontopatijom kao i ispitivanje uticaja kauzalne terapije parodontopatije na stepen oksidativnog stresa u krvi. Rezultati našeg istraživanja, međutim, u najvećoj meri nisu potvrdili prethodno iznete stavove. Naime, rezultati našeg istraživanja pokazuju da su pacijenti sa parodontopatijom imali gotovo istu vrednost $8-\mathrm{OHdG}$ u $\mathrm{krvi}(0,472 \mathrm{ng} / \mathrm{ml})$ kao i ispitanici sa zdravim parodoncijumom $(0,449 \mathrm{ng} / \mathrm{ml})$. Raspon vrednosti $8-\mathrm{OHdG}$ iznosio je 0,262-0,812 ng/ml kod pacijenata sa parodontopatijom i 0,113-1,000 ng/ml kod zdravih ispitanika. Iako smo konstatovali više vrednosti ovog markera u grupama sa većom dubinom sondiranja i $\mathrm{NPE} \geq 3 \mathrm{~mm}$, ove razlike nisu dostigle statistički značajan nivo. Isto tako, iako je postojala pozitivna korelacija 8-OHdG u pljuvački i krvi pacijenata sa parodontopatijom ona nije bila statistički značajna $(p=0,324)$. Naše nalaze je teško porediti sa drugima jer je mali broj studija koje su ispitivale oksidativno oštećenje DNK u krvi pacijenata sa parodontopatijom. Jedina studija na ljudima, koliko je nama poznato, je studija Konopke i 
sar. (131) koji su poredeći vrednosti 8-OHdG i totalnog antioksidativnog kapaciteta (TAOC) u gingivalnoj krvi i sistemskoj cirkulaciji pacijenata sa hroničnom i agresivnom parodontopatijom i pacijenata sa zdravim parodoncijumom, utvrdili znatno više vrednosti i 8-OHdG i TAOC u gingivalnoj krvi kod obe grupe pacijenata sa parodontopatijom u odnosu na zdrave ispitanike. U sistemskoj cirkulaciji, međutim, nalaze značajnu razliku samo za TAOC dok se vrednosti 8-OHdG nisu razlikovale među ispitivanim grupama. Autori izveštavaju i o značajnoj korelaciji između TAOC u gingivalnoj krvi i sistemskoj cirkulaciji, dok korelacije 8-OHdG i TAOC sa kliničkim parametrima nisu zabeležene. Sa druge strane, Ekuni i sar. (132) ispitujući nivo oksidativnog oštećenja DNK u krvi životinja sa eksperimentalno izazvanom parodontopatijom u odnosu na one sa zdravim parodoncijumom, beleže značajno više vrednosti 8-OHdG u grupi sa parodontopatijom. Autori zaključuju da nivo ovog markera u krvi reflektuje stanje parodoncijuma i da je 8OHdG koristan biomarker oksidativnog oštećenja, te predlažu njegovu upotrebu uporedo sa citokinima za praćenje sistemskog inflamatornog odgovora u toku oboljenja potpornog aparata zuba. Ekuni i sar. izveštavaju i o značajnom smanjenju 8-OHdG u krvi esperimentalnih životinjama nakon mehaničke stimulacije gingive, za koju navode da dovodi do poboljšanja cirkulacije, smanjenja zapaljenske ćelijske infiltracije, povećane sinteze kolagena i unapređenja proliferativnih sposobnosti epitelnih ćelija i fibroblasta. Stoga, autori zaključuju da redukcija inflamacije nakon stimulacije gingive utiče na smanjenu produkciju reaktivnih kiseoničnih vrsta i smanjen prenos oksidativnog stresa iz parodoncijuma u sistemsku cirkulaciju (132).

Naši pak rezultati ne potvrđuju ovakve zaključke. Analizirajući vrednosti 8-OHdG u krvi pacijenata sa parodontopatijom posle sprovedene kauzalne terapije, utvrdili smo da ona nije dovela do smanjenja ovog markera, niti je imala uticaj na nivo 8-OHdG kada su pacijenti podeljeni prema stepenu inflamacije, dubini sondiranja i nivou pripojnog epitela.

Istraživanja pokazuju da proizvodi lipidne peroksidacije difunduju sa mesta inflamacije i da se produkti lipidne peroksidacije kod parodontopatije mogu registrovati u sistemskoj cirkulaciji (250). Sobaniec i sar. su vršili morfološka ispitivanja čvrstih tkiva parodoncijuma na laboratorijskim životinjama sa eksperimentalno izazvanom parodontopatijom i pri tome pratili koncentraciju MDA i aktivnost antioksidativnih 
enzima superoksid-dizmutaze, glutation peroksidaze i glutation reduktaze. Studija je pokazala da postoji povećanje nivoa MDA i smanjenje nivoa antioksidanata u krvi životinja sa parodontopatijom. Slični rezultati dobijeni su i kod ljudi. Tako Panjamurthy i sar. (140) izveštavaju o višim vrednostima markera lipidne peroksidacije (TBARS) u krvi pacijenata sa parodontopatijom $(10,34 \mathrm{nmol} / \mathrm{ml})$ nego kod pacijenata sa zdravim parodoncijumom $(4,79 \mathrm{nmol} / \mathrm{ml})$, dok Dhotre i sar. (251) beleže značajno više vrednosti MDA u grupi sa parodontopatijom $(6,55 \mathrm{nmol} / \mathrm{ml})$, u odnosu na kontrolnu grupu $(3,71$ $\mathrm{nmol} / \mathrm{ml})$.

I rezultati našeg istraživanja idu u tom pravcu. Naime, vrednost MDA u krvi naših pacijenata sa parodontopatijom $(0,497 \mathrm{pmol} / \mu \mathrm{l})$ je bila statistički značajno viša od vrednosti kod zdravih pacijenata $(0,398 \mathrm{pmol} / \mu \mathrm{l})$. Iako postoji mogućnost da je povišena koncentracija MDA u krvi posledica nekog drugog patološkog procesa u organizmu, mišljenja smo da je ona ipak posledica parodontopatije. Na to nas upućuje činjenica da su svi naši pacijenti bili sistemski zdravi, kao i činjenica da rezultati našeg istraživanja pokazuju statističku značajnu pozitivnu korelaciju MDA u pljuvački sa vrednosti ovog markera u krvi. Zbog toga možemo pretpostaviti da je upravo lokalno povećanje MDA dovelo i do njegovih viših sistemskih vrednosti. O pozitivnoj korelaciji između lokalnih patoloških događanja u parodontalnom tkivu i sistemskog poremećaja lipidnog metabolizma izveštavaju i Daković i sar. (209).

Nasuprot tome, Wei i sar. beleže slične vrednosti MDA u krvi pacijenata sa parodontopatijom $(0,72 \mathrm{mM})$ i pacijenata sa zdravim parodoncijumom (0,68 $\mathrm{mM})(140)$, dok Akalin i sar. dobijaju $0,60 \mu \mathrm{M}$ kod pacijenata sa parodontopatijom i $0,58 \mu \mathrm{M}$ kod zdravih pacijenata (126). Obe grupe autora izveštavaju o značajnom lokalnom porastu MDA u gingivalnoj tečnosti pacijenata sa parodontopatijom, dok porast sistemskog MDA kod njihovih pacijenata nije bio značajan. Akalin i sar. su mišljenja da je MDA pokazatelj porasta lokalnog oksidativnog stresa dok su za porast sistemskog oksidativnog stresa značajniji oksidativna modifikacija proteina i poremećaj antioksidativnog kapaciteta.

Bastos i sar. ispitujući proces lipidne peroksidacije kod pacijenata sa parodontopatijom, izveštavaju o značajnoj korelaciji MDA u krvi sa lokalno proizvedenim inflamatornim citokinima (IL-10 i TNF $\alpha$ ), ističući da je ovaj marker validan pokazatelj 
ozbiljnosti inflamatornog procesa (252). I rezultati našeg istraživanja pokazuju da je na visoku vrednost MDA u krvi pacijenata sa parodontopatijom najviše uticala upravo inflamacija gingive. Naime, kod pacijenata sa izraženom inflamacijom $(0,548 \mathrm{pmol} / \mu \mathrm{l})$ ovaj marker je bio statistički značajno viši od vrednosti kod pacijenata sa umerenom inflamacijom gingive $(0,451 \mathrm{pmol} / \mu \mathrm{l})(\mathrm{p}=0,047)$. Ovo vidimo kao još jedan dokaz koji ide u prilog zaključku da su inflamatorni procesi u parodoncijumu naših pacijenata doveli do porasta kako lokalne tako i sistemske lipidne peroksidacije.

Preduzeta terapija, međutim, nije dovela do pada koncentracije MDA u krvi naših pacijenata, te je MDA i nakon terapije bio viši kod pacijenata sa parodontopatijom u odnosu na zdrave ispitanike $(p=0,059)$. Slični našim su i rezultati Wei i sar. (170) koji izveštavaju o gotovo jednakim vrednostima ovog markera u krvi pre i posle terapije. Sonoki i sar. (253) beleže, međutim, značajno smanjenje vrednosti LPO u krvi kod pacijenata sa dijabetesom i parodontopatijom posle kauzalne terapije, kada se LPO izjednačio sa vrednosti kod pacijenata koji nisu imali dijabetes. Autori sugerišu da smanjenje intenziteta LPO nakon kauzalne terapije parodontopatije kod obolelih od dijabetesa ukazuje da bi parodontološka terapija mogla da ima antioksidativni efekat kod ovih pacijenata. Sa druge strane, terapija nije dovela do smanjenja LPO u grupi pacijenata sa parodontopatijom, što objašnjavaju mnogo većim vrednostima LPO kod pacijenata sa dijabetesom na početku terapije.

Iako je na vrednost MDA u krvi naših pacijenata sa parodontopatijom na početku istraživanja najviše uticala inflamacija gingive, njeno značajno smanjenje nakon preduzete terapije nije pratilo i značajno smanjenje MDA. Na smanjenje MDA nakon terapije najviše je uticala redukcija dubine sondiranja kod pacijenata sa većom dubinom sondiranja. Naime, vrednost MDA kod pacijenata sa većom dubinom sondiranja je pre terapije bila znatno viša nego kod pacijenata sa manjom dubinom sondiranja $(p=0,083)$, da bi nakon terapije došlo do statistički značajnog smanjenja MDA samo u grupi pacijenata sa većom dubinom sondiranja. Ovakav nalaz mogao bi upućivati na zaključak da bi terapija parodontopatije mogla imati veći efekat na smanjenje lipidne peroksidacije u cirkulaciji kod pacijenata sa težom formom parodontopatije. 
Ispitujući koncentaciju antioksidativnog enzima superoksid-dismutaze, Kale i sar. (254) i Wei i sar. (170), izveštavaju o statistički značajnom povećanju koncentracije SOD u krvi kod pacijenta sa parodontopatijom. Wei i sar. (170) dalje izveštavaju i o statistički značajnom smanjenju vrednosti SOD u krvi nakon parodontološke terapije. Rezultati našeg istraživanja, međutim, ne potvrđuju ove navode. Naši rezultati pokazuju gotovo jednake vrednosti kako koncentracije tako i aktivnosti SOD u krvi paciijenata sa parodontopatijom $(1,789 \mathrm{U} / \mu 1,47,822 \%)$ i zdravih ispitanika $(1,774 \mathrm{U} / \mu 1,45,050 \%)$, kao i gotovo jednake vrednosti koncentacije $i$ aktivnosti SOD u krvi pacijenata sa parodontopatijom pre $(1,789 \mathrm{U} / \mu 1,47,822 \%)$ i posle terapije $(1,772 \mathrm{U} / \mu 1,47,061 \%)$. Pored razlike u metodologiji među ovim studijama postoji i razlika u težini parodontopatije ispitanika. Naime, naši pacijenti su imali značajno manji stepen destrukcije parodoncijuma od pacijenata u prethodno navedenim studijama. Ova razlika je, po našem mišljenju, mogla da dovede do značajno viših vrednosti SOD u pomenutim istraživanjima jer upravo ovi autori ističu bitan uticaj dubine parodontalnih džepova na vrednosti SOD u krvi. Poredeći vrednosti SOD u krvi naših pacijenata u zavisnosti od stepena inflamacije, dubine sondiranja i nivoa pripojnog epitela mi nismo ustanovili postojanje razlike među ispitivanim grupama.

Jedan deo ovog istraživanja odnosio se i na uticaj pušenja na stepen oksidativnog stresa kod pacijenata sa parodontopatijom. Pušenje povećava izloženost slobodnim radikalima (255) dok sa druge strane smanjuje antioksidativnu zaštitu organizma (256). Pušači su izloženi dejstvu više od 4000 hemikalija iz cigareta i slobodnih radikala koji nastaju njihovim sagorevanjem. Utvrđeno je da se tokom konzumiranja jedne cigarete stvori $1 \times 10^{16}$ slobodnih radikala (255) te da pušenje pogoršava "respiratornu eksploziju" u polimorfomuklearnim leukocitima povećanjem proizvodnje ROS, posebno peroksinitrita $\mathrm{ONOO}^{-}(257)$.

Istovremeno pušenje je jedan od glavnih akcesornih faktora $u$ nastanku parodontopatije koji utiče na brojne aspekte imunog odgovora domaćina. Pušenje ima negativan efekat na funkciju fibroblasta, hemotaksu i fagocitozu a dovodi i do smanjene produkcije imunoglobulina. Autori ističu da parodontopatija kod pušača ima težu kliničku sliku, da se manifestuje većim brojem dubokih parodontalnih džepova, znatnim gubitkom 


\section{Diskusija}

pripoja (258), bržom resorpcijom alveolarne kosti i gubitkom većeg broja zuba u kraćem vremenskom periodu (259).

Rezultati našeg istraživanja pokazuju znatno veći stepen kako lokalnog tako i sistemskog oksidativnog stresa kod pušača. Naime, u pljuvački pacijenata sa parodontopatijom vrednosti sva tri ispitivana markera bile su statistički značajno više kod pušača u odnosu na nepušače. Isto tako, vrednosti MDA i SOD u krvi bile su statistički značajno više kod pušača. I 8-OHdG u krvi je takođe bio viši kod pušača ali ta razlika u odnosu na nepušače nije bila statistički značajna. Naime, vrednost 8-OhdG je iznosila $1,181 \mathrm{ng} / \mathrm{ml}$ u pljuvački a $0,556 \mathrm{ng} / \mathrm{ml}$ u krvi pušača, odnosno $0,713 \mathrm{ng} / \mathrm{ml}$ u pljuvački i 0,430 ng/ml u krvi nepušača. Do sada, koliko je nama poznato, nisu rađene studije kod pacijenata sa parodontopatijom koje su ispitivale stepen oksidativnog oštećenja DNK u zavisnosti od navike pušenja. Postoje, međutim, istraživanja na zdravim ispitanicima, koja su merila vrednost urinarnog 8-OHdG. Tako Loft i sar. (260) izveštavaju da pušenje povećava oksidativno oštećenje DNK za 50\%, dok Li i sar. (261) beleže gotovo trostruko veće vrednosti $8-O H d G$ kod pušača $(18 \mu \mathrm{mol} / \mathrm{mol})$, nego kod nepušača $(6,3 \mu \mathrm{mol} / \mathrm{mol})$. Iako ova istraživanja nisu uključivala parodontološki status pacijenata, možemo zaključiti da je stepen oksidativnog oštećenja DNK značajno veći kod pušača u odnosu na nepušače, što potvrđuju i rezultati našeg istraživanja.

Vrednost MDA je u našem istraživanju iznosila 4,069 $\mathrm{pmol} / \mu \mathrm{l}$ u pljuvački a 0,570

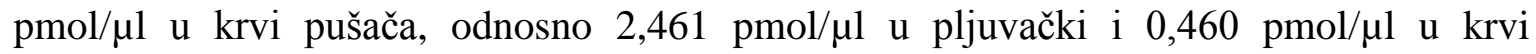
nepušača. Guentsch i sar. (262) izveštavaju o progresivnom povećanju vrednosti MDA u pljuvački od zdravih nepušača $(0,0065 \mu \mathrm{mol} / 1)$ ka zdravim pušačima $(0,085 \mu \mathrm{mol} / 1)$ i dalje ka nepušačima $(0,095 \mu \mathrm{mol} / 1)$ i pušačima $(0,123 \mu \mathrm{mol} / 1)$ sa parodontopatijom. Oni takođe izveštavaju i o višim vrednostima MDA u krvi pušača sa parodontopatijom u odnosu na vrednosti kod zdravih nepušača. Autori zaključuju da pušenje može pojačati efekat ROS kod pacijenata sa parodontopatijom i povećati razaranje tkiva usled oksidativnog stresa. Garg i sar. (263) ukazuju da na nivo MDA u gingivalnom tkivu utiče i broj popušenih cigareta. Slično našim rezultatima, ovi autori beleže znatno više vrednosti MDA u krvi pušača u odnosu na nepušače sa parodontopatijom. Više vrednosti MDA kod pušača objašnjavaju porastom produkcije slobodnih radikala kao direktnog uticaja pušenja ili 
putem aktivacije polimorfonuklearnih leukocita. Kao i u pljuvački, autori ističu da na vrednost MDA u krvi kod pacijenata sa parodontopatijom utiče broj popušenih cigareta $u$ toku dana. I Tonguc i sar. (264) poredeći nivo MDA u gingivalnom tkivu pušača, bivših pušača i nepušača, beleže značajnu razliku u vrednostima ovog markera među ispitivanim grupama.

Pušenje može da dovede i do izmenjene aktivnosti antioksidativnih enzima. Literaturni podaci međutim, govore kako o povećanju tako i o smanjenju aktivnosti SOD kod pušača u odnosu na nepušače. Tako Garg i sar. (263) i Agnihotri i sar. (265) izveštavaju da je pušenje povezano sa nižim vrednostima SOD kod pacijenata sa parodontopatijom, navodeći da to može biti posledica inaktivacije ovog enzima od strane vodonik peroksida. Yildiz i sar. (266) zaključuju da niže vrednosti SOD kod pušača mogu da dovedu do nagomilavanja ROS nastalih iz duvanskog dima. Sa druge strane, Kanehira i sar. (267) beleže više vrednosti SOD u grupi pušača sa parodontopatijom, sugerišući da povećan nivo superoksid-dismutaze kod pušača predstavlja zaštitni mehanizam od slobodnih radikala čije je stvaranje izazvano duvanskim dimom. Naši rezultati su u skladu sa ovim istraživanjem. Naime, vrednost SOD je kod naših pacijenata iznosila $0,387 \mathrm{U} / \mu \mathrm{l} u$

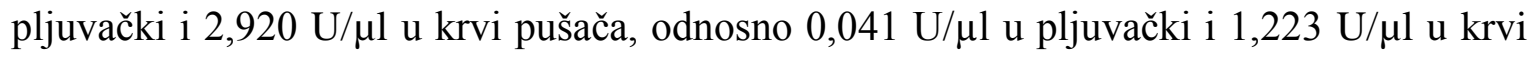
nepušača. Ovi nalazi su u saglasnosti i sa rezultatima Aziz i sar. (268) i Tonguc i sar. (264), koji su takođe u krvi pušača sa parodontopatijom zabeležili više vrednosti SOD u odnosu na nepušače. Sa druge strane, Reejamol i sar. (269) izveštavaju o nižim vrednostima SOD u krvi pušača u odnosu na nepušače kao posledice inaktivacije SOD od strane vodonik peroksida čija se proizvodnja povećava u toku pušenja.

Rezultati našeg istraživanja dalje pokazuju da je preduzeta parodontološka terapija dovela do statistički značajnog smanjenja 8-OHdG i MDA u pljuvački naših pacijenata i u grupi pušača i u grupi nepušača. Isto tako i SOD je značajno smanjen u grupi pušača, dok u grupi nepušača beleži blagi porast zbog ekstremno visokih vrednosti kod jednog pacijenta. Rezultati nadalje pokazuju da je parodontološka terapija osim lokalnog dovela i do smanjenja sistemskog oksidativnog stresa u grupi pušača. Naime, iako su 3 meseca nakon terapije vrednosti 8-OHdG i SOD ostale gotovo nepromenjene u odnosu na vrednosti pre terapije, MDA je bio značajno niži u ovoj grupi pacijenata. Sa druge strane, 
u grupi nepušača terapija nije imala uticaj na smanjenje sistemskog oksidativnog stresa. Mišljenja smo da je ovakav rezultat posledica značajno viših vrednosti MDA u grupi pušača na početku istraživanja. 


\section{ZAKLJUČCI}

1. Pacijenti sa parodontopatijom imali su značajno više vrednosti svih ispitivanih markera oksidativnog stresa $u$ pljuvački od pacijenata sa zdravim parodoncijumom.

2. Pacijenti sa parodontopatijom imali su značajno više vrednosti markera lipidne peroksidacije (MDA) u krvi od pacijenata sa zdravim parodoncijumom. Vrednosti markera oksidativnog oštećenja DNK (8-OHdG) i antioksidantnog enzimasuperoksid dismutaze (SOD) u krvi pacijenata sa parodontopatijom i pacijenata sa zdravim parodoncijumom nisu se razlikovale.

3. Kauzalna terapija parodontopatije dovela je do značajnog smanjenja vrednosti svih ispitivanih markera oksidativnog stresa $u$ pljuvački kod pacijenata sa parodontopatijom.

4. Kauzalna terapija parodontopatije nije imala uticaja na vrednosti markera oksidativnog stresa u krvi kod pacijenata sa parodontopatijom. 


\section{LITERATURA}

1. Sies H. Oxidative stress: from basic research to clinical application. Am J Med 1991;91:31-8.

2. Wakamatsu TH, Dogru M, Tsubota K. Tearful relations: oxidative stress, inflammation and eye diseases, Arq Bras Oftalmol 2008;71:72-9.

3. Valko M, Leibfriz D, Moncol J, Cronin MT, Maur M, Telser J. Free radicals and antioxidants in normal physiological functions and human disease. Int J Biochem Cell B 2007;39:44-84.

4. Đukić M. Oksidativni stres - Kliničko dijagnostički značaj. Beograd: Mono i Manjana; 2008.

5. Stevanović J, Borozan S, Jović S, Ignjatović I. Fiziologija slobodnih radikala. Vet Glasnik 2011;65:95-107.

6. Halliwell B, Gutteridge JMC. Free radicals in biology and medicine. New York: Oxford University Press;1999.pp.617-783.

7. Gómez LA, Hagen TM. Age-related decline in mitochondrial bioenergetics: Does supercomplex destabilization determine lower oxidative capacity and higher superoxide production? Semin Cell Dev Biol 2012;23:758-67.

8. Đukić MM. Oksidativni stres. Slobodni radikali, prooksidansi, antioksidansi. Mono i Manjana. Beograd, 2008.

9. Bondy SC, Nadery S. Contribution of hepetic cytochrome P-450 systems to the generation of rective oxygen species. Biochem Pharmacol 1994;48:155-9. 
10. Valko M, Rhodes CJ, Moncola J, Izakovic M, Mazura M. Free radicals, metals and antioxidants in oxidative stress-induced cancer. Chem-Biol Interact 2006;160:1-40.

11. Arsić A. Uticaj hroničnog intenzivnog treninga na parameter oksidativnog stresa I masnokiselinski profil plazme i eritocita kod sportiskinja. Doktorska disertacija Beograd, 2012.

12. Pastor N, Weinstein H, Jamison E, Brenowitz M. A detailed interpretation of OH radical footprints in a TBP-DNA complex reveals the role of dynamics in the mechanism of sequencespecific binding. J Mol Cell Biol 2000; 304:55-68.

13. Halliwell B GJ. Free radicals in biology and medicine. Third edition. Oxford: Oxford University Press 1999;246-320.

14. Knowels R, Moncada S. Nitric oxide synhases in mammals. Biochem J 1994; 298: 24958.

15. Jelenković A. Mesto i značaj azot oksida u patogenezi konvulzija i u delovanju antikonvulziva. Doktorska disertacija Beograd, 1998.

16. Jelenković A, Jovanović M, Ninković M, Maksimović M, Bokonjić D, Bošković B. Nitric oxide and convulsions induces by pentylenetetrazol. Ann NY Acad Sci 2002;962:296-305.

17. Jelenković A, Jovanović M, Ninković M, Maksimović M, Bošković B. Total anaesthesia, rats, brain surgery, nitric oxide (NO) and free radicals. Acta Vet-Beograd 2005;55:375-83.

18. Jovičić A, Ivanišević V, Marković M, Simović M. Uloga azotnog oksida u fizioloških funkcijama i patološkim stanjima. Vojnosanit Pregl 1994;51:126-31.

19. Beckman J, Beckman T, Chen J, Marshall P, Freeman B. Apparent hydroxil radical production by peroxinitrite: implications for endothelial injury from nitric oxide and superoxide. P Natl Acad Sci USA 1991;87:1620-4. 
20. Đorđević BV, Pavlović DD, Kocić MG. Biohemija slobodnih radikala. Niš, Medicinski fakultet, 2000.

21. Babior BM, Lamberth JD, Nauseef W. The neutrofil NADPH oxidase. Arch Biochem Biophys 2002;397:342-4.

22. Fantone JC, Ward PA. Role of oxygen-derived free radicals and metabolites in leukocyte-dependent inflammatory reactions. Am J Pathol 1982;107:395-418.

23. Pavlović D, Đorđević V, Kocić G. Ćelijska signalna transdukcija - modulacija slobodnim radikalima. Jugoslav Med Biohem 2002;21:69-84.

24. Katanić J. Uticaj nanočestice fulerenola na modulaciju aktivnosti antioksidativnog sistema malignih ćelija. Doktorska disertacija Novi Sad, 2012.

25. Forman HJ. Reactive oxygen species and $\alpha, \beta$-unsaturated aldehydes as second messengers in signal transduction. Ann NY Acad Sci 2010;1203:35-44.

26. Cerutti PA. Oxy-radicals and cancer. Lancet 1994;344:862-3.

27. Pavlović D, Kocić G, Đorđević V. Ćelijska signalizacija u kontroli ćelijskog ciklusa, apoptoze i maligne transformacije Acta Fac Med Naiss 2002;19:12-8.

28. Curtin JF. Regulation and measurement of oxidative stress in apoptosis. J Immunol Methods 2002;265:49-72.

29. Boehm I. Apoptosis in physiological and pathological skin: implications for therapy. Curr Mol Med 2006;6:375-94.

30. Nagata S, Gostein P. The Fas death factor. Science 1995;267:1449-56.

31. Chinnaiyan AM, O'Rourke K, Tewari M, Dixit VM. FADD, a novel death domaincontaining protein, interacts with the death domain of Fas and initiates apoptosis. Cell 1995;81:505-12. 
32. Cassina A, Radi R. Differential inhibitory action of nitric oxide and peroxynitrite on mitochondrial electron transport. Arch Biochem Biophys 1996;328:309-16.

33. Chazotte AL., Pluquet O, Hainaut P, Ohshima H. Nitric oxide prevents gammaradiation-induced cell cycle arrest by impairing p53 function in MCF-7 cells. Biochem Bioph Res Co 2001;281:766-71.

34. Greenberg ME, Li XM, Gugiu BG, Gu X, Qin J, Salomon RG et al.. The lipid Whisker model of the structure of oxidized cell membranes. J Biol Chem 2008;283:2385-96.

35. West JD, Marnett LJ. Endogenous reactive intermediates as modulators of cell signaling and cell death. Chem Res Toxicol 2006;19:173-94.

36. Laguerre $\mathrm{M}$, Leconte $\mathrm{J}$, Villeneuve $\mathrm{P}$. Evaluation of ability of antioxidants to counteract lipid oxidation: Existing methods, new trend and challenges. Prog Lipid Res 2007;46:244-82.

37. Esterbauer H, Wag G, Puhl H. Lipid peroxidation and its role in atherosclerosis. Brit Med Bull 1993;49:566-76.

38. Boyd NF, Mcguire V. The possible role of lipid peroxidation in breast cancer risk. Free Radical Bio Med 1991;10:185-90.

39. Markesbery WR, Lovell MA. Four-hydrononenal, a product of lipid peroxidation is increased in the brain in Alzheimer's disease. Neurobiol Aging 1998;19:33-6.

40. Ceaser EK, Moellering DR, Shiva A, Ramachandran A, Lander A, Venkartraman A et al. Mechanisms of signal transduction mediated by oxidized lipids: the role of the electrophile-responsive proteome. Biochem Soc T 2004;32:151-5.

41. Poli G, Schaur RJ, Siems WG, Leonarduzzi G. 4-Hydroxynonenal: a membrane lipid oxidation product of medicinal interest. Med Res Rev 2008;28:569-631. 
42. Noguchi N. Role of oxidative stress in adaptive responses in special reference to atherogenesis. J Clin Biochem Nutr 2008;43:131-8.

43. Parthasarathy S, Santanam N, Ramachandran S, Meilhac O. Potential role of oxidized lipids and lipoproteins in antioxidant defense. Free Radical Res 2000; 33:197-215.

44. Frankel EN. Lipid oxidation:Mechanisms, Products and Biological Significance. J Am Oil Chem Soc 1984;61:1908-17.

45. Đukić M, Jovanović M, Nedeljković M, Milić B. Indeks lipidne peroksidacije u plazmi alkoholičara u toku terapije disulfiramom. Jugoslav Med Biochem 1996;15:285.

46. Jovičić A, Mihajlović R, Jovanović M, Čolić M, Selaković MV. Content of malondialdehyde and TGF-b in the CSF of patients in the acute phase of completed stroke. Eur J Neurol 2000;(suppl):110.

47. Sheu J.Y, Chen P.H, Tseng W.C, Chen C.Y, Tsai L.Y, Huang Y.L. Spectropfotometric determination of a thiobarbituric acid-reactive substance in human hair. Anal Sci 2003; 19:957-60.

48. Del Rio D, Stewart A, Pellegrini N. A review of recent studies on malondialdehyde as toxic molecule and biological marker of oxidative stress. Nutr Metab Cardiovasc 2005; 15:316-28.

49. Ilhan N, Ilhan N, Simsek M. The changes of trace elements, malondialdehyde levels and superoxide dismutase activities in pregnancy with or without preeclampsia. Clin Biochem 2002;35:393-7.

50. Polidori MC, Savino K, Alunni G, Freddio M, Senin U, Sies H et al. Plasma lipophilic antioxidants and malondialdehyde in congestive heart failure patients: relationship to disease severity. Free Radical Bio Med 2002;32:148-52. 
51. Loguercio C, Federico A. Oxidative stress in viral and alcoholic hepatitis. Free Radical Bio Med 2003;34:1-10.

52. Delibas N, Ozcankaya R, Altuntas I. Clinical importance of erythrocyte malondialdehyde levels as a marker for cognitive deterioration in patients with dementia of Alzheimer type: a repeated study in 5-year interval. Clin Biochem 2002;35:137-41.

53. Leuratti C, Watson MA, Deag EJ, Welch A, Singh R, Gottschalg E, et al. Detection of malondialdehyde DNA adducts in human colorectal mucosa: relationship with diet and the presence of adenomas. Cancer Epidem Biomar 2002;11:267-73.

54. Zhang Y, Chen SY, Hsu T, Santella RM. Immunohistochemical detection of malondialdehyde-DNA adducts in human oral mucosa cells. Carcinogenesis 2002;23:20711.

55. Stadtman ER, Berlett SB. Free-Radical-Mediated Modification of Proteins. In: Free radical Toxycology, Ed. Wallace KB, Taylor\&Francis, NY,1997.

56. Stadtman ER, Levine RL. Free radical-mediated oxidation of free amino acids and amino acid residues in proteins. Amino Acids 2003;25:207-18.

57. Shacter E. Quantification and significance of protein oxidation in biological samples. Drug Metab Rev 2000;32:307-26.

58. Beal MF. Oxidatively modified proteins in aging and disease. Free Radical Bio Med 2002;32:797-803.

59. Sies H. Oxidative stress: Oxidants and antioxidants. Exp Physiol 1997;82:291-5.

60. Ames BN, Shigenaga MK, Hagan TM. Oxidants, antioxidants, and the degenerative diseases of aging. Proc Natl Acad Sci USA 1993;90:7915-22.

61. Halliwell B. Antioxidants: the basics--what they are and how to evaluate them. Adv pharmacol 1997;38:3-20. 
62. Mc Cord JM, Fridovich I. Free radicals and inflammation: protection of sinovial fluid by superoxide dismutase. Science 1974;185:529-31.

63. Halliwell B. Free radicals and antioxidants: a personal view. Nutr Rev 1994;52:25365.

64. Fridovich I. Superoxide dismutases: studies of structure and mechanism. Adv Exp Med Biol 1976;74:530-9.

65. Fridovich I. Superoxide dismutases. Adv Enzymol Relat Areas Mol Biol 1986; 58: 6197.

66. Faraci FM, Didion SP. Vascular protection: superoxide dismutase isoforms in the vessel wall. Arterioscler Thromb Vasc Biol 2004;24:1367-73.

67. MacMillan-Crow LA, Cruthirds DL. Manganese superoxide dismutase in disease. Free Radical Res 2001;34:325-36.

68. Didion SP, Ryan MJ, Didion LA, Fegan PE, Sigmund CD, Faraci FM. Increased superoxide and vascular dysfunction in CuZnSOD-deficient mice. Circ Res 2002;91:93844.

69. Prasad AS, Beck FWJ, Bao B, Snell D, Fitzgerald JT. Duration and severity of symptoms and levels of plasma interleukin-1 receptor antagonist, soluble tumor necrosis factor receptor and adhesion molecules in patients with common cold treated with zinc acetate. J Infect Dis 2008;197:795-802.

70. Laughlin MH, Welshons WV, Sturek M, Rush JWE, Turk JR, Taylor JA et al. Gender, exercise training, and eNOS expression in porcine skeletal muscle arteries. J Appl Physiol 2003;95:250-64.

71. Shull S, Nicholas HH, Periasamy M, Manohar M, Janssen MWI, Marsh PJ et al. Differential regulation of antioxidant enzymes in response to oxidants. J Biol Chem 1991;266:24398-403. 
72. Suresh A, Guedez L, Moreb J, Zucali J. Overexpression of mangane superoxide dismutase promotes survival in cell lines after doxorubicin treatment. Brit J Haematol 2003;120:457-63.

73. Kinulla VL, Crapo JD. Superoxid dismutases in malignat cells and human tumors. Free Radical Bio Med 2004;36:718-44.

74. Mohr A, Buneker C, Gough RP, Zwacka RM. MnSOD protects colorectal cancer cells from TRAIL-induced apoptosis by inhibition of Smac/DIABLO release. Oncogene 2008;27:762-74.

75. Zelko IN, Mariani TJ, Folz RJ. Superoxide dismutase multigene family: a comparison of the CuZn-SOD (SOD1), Mn-SOD (SOD2), and EC-SOD (SOD3) gene structures, evolution, and expression. Free Radical Bio Med 2002;33:337-49.

76. Fukai T. Extracellular SOD and aged blood vessels. Am J Physiol-Heart C 2009;297:10-2.

77. Michelson MA. Medical aspects of superoxide dismutase. Life Chem Rep 1987;6:1142.

78. Reddy VN, Kasahara E, Hiraoka M, Lin YS, Ho YS. Effects of variation in superoxide dismutases (SOD), on oxidative stress and apoptosis in lens epithelium. Exp Eye Res 2004;79:859-68.

79. Žorić L, Jovanović P. Oksidacioni stres u patogenezi očnih bolesti. Medicinski fakultet Niš. Sven, 2006.

80. Dröge W. Free radicals in the physiological control of cell function. Physiol rev 2002; 82:47-95. 
81. Imai $\mathrm{H}$, Nakagawa $\mathrm{Y}$. Biological significance of phospholipid hydroperoxide glutathione peroxidase (PHGPx, GPx4) in mammalian cells. Free Radical Bio Med 2003;34:145-69.

82. Uhlig S, wendel A. The physiological consequenses of glutation variations. Life Sci 1992;51:1083-94.

83. Beutler TM, Eatan DL. Glutathione-S-transferases: amino acid sequence comparison, classification and phylogenetic relationship. J Environ Sci Heal C 1992;10:181-203.

84. Hazes PC, Bouchier IA, Beckett GJ. Glutathione-S-transferase in humans in health and disease. Gut 1991;32:813-8.

85. Wright JS, Johnson ER, DiLabio GA. Predicting the activity of phenolic antioxidants: Theoretical method, analysis of substituents effects, and application to major families of antioxidants. J Am Chem Soc 2001;123:1173-83.

86. Bergendi L, Beneš L, Duraĉkova Z, Ferenĉik M. Chemistry, physiology and pathology of free radicals. Life Sci 1999;65:1865-74.

87. van Haaften RI, Haenen GR, Evelo CT, Bast A. Effect of vitamin E on glutathionedependent enzymes. Drug Metab Rev 2003;35:215-53.

88. Page RC, Kornman K. The pathogenesis of human periodontitis:an introduction. Periodontol 2000 1997;14:9-11.

89. Cesaratto L, Vascotto C, Calligaris S, Tell G. The importance of redox state in liver damage. Ann Hepatol 2004;3:86-92.

90. Jozanov-Stankov O, Dobutović DB, Djuric J, Isenović ER. Okidativni stres kao činilac kod oboljevanja i patoloških poremećaja ljudi. Apoll Med Aescul 2007;5:31-6.

91. Đajić D, Đukanović D, Stanić S, Kovačević K. Bolesti usta, parodontologija, atlas. Beograd: Elit Medica; 2001. 
92.Zambon J. Periodontal diseases: microbial factors. Ann Periodontol 1996; 1: 879-925.

93. Consesus report. Periodontal diseases: Pathogenesis and microbial factors. Ann Periodontol 1996;1:926-32.

94. Wolff L, Dahlen G, Aeppli D. Bacteria as risk markers for periodontitis. J Periodontol 1994;65:498-510.

95. Kinane DF. Causation and pathogenesis of periodontal disease. Periodontol 2000. 2001;25:8-20.

96. Halliwell B. Oral inflammation and reactive species: a missed opportunity? Oral Dis 2000;6:136-7.

97. Halliwell B, Whiteman M. Measuring reactive species and oxidative damage in vivo and in cell cultures: how should you do it and what do the results mean? Brit J Pharmacol 2004;142:231-55.

98. Chapple ILC, Matthews JB. The role of reactive oxygen and antioxidant species in periodontal tissue destruction. Periodontol 2000 2007;43:160-232.

99. Brock GR, Butterworth CJ, Matthews JB, Chapple IL. Local and systemic total antioxidant capacity in periodontitis and health. J Clin Periodontol 2004; 31:515-21.

100. Moore S, Calder KA, Miller NJ, Rice-Evans CA. Antioxidant activity of saliva and periodontal disease. Free Radical Res 1994;21:417-25.

101. Ozmeric N. Advances in periodontal disease markers. Clin Chim Acta 2004; 343:116.

102. Nagler RM, Klein I, Zarzhevsky N, Drigues N, Reznick AZ. Characterization of the differentiated antioxidant profile of human saliva. Free Radical Bio Med 2002;32:268-77.

103. Sculley DV, Langley-Evans SC. Salivary antioxidants and periodontal disease status. P Nutr Soc 2002;61:137-43. 
104. Canakci CF, Ciceki Y, Canakci V. Reactive oxygen species and human inflammatory periodontal diseases. Biochem (Mosc) 2005;70:619-28.

105. Waddington RJ, Moseley R, Embery G. Reactive oxygen species: a potential role in the pathogenesis of periodontal diseases. Oral Dis 2000;6:138-51.

106. Giannobile WV. C-telopeptide pyridinolone cross-links. Sensitive indicators of periodontal tissue destruction. Ann NY Acad Sci 1999;30:404-12.

107. Mukhopadhyay CK, Chatterjee IB. Free metal iondependent oxidative damage of collagen. Protection by ascorbic acid. J Biol Chem 1994;269:30200-5.

108. Rittie L, Monbiosse J-C, Gorisse M-C, Gillery P. Malondialdehyde binding to proteins dramatically alters fibroblast functions. J Cell Physiol 2002;191:227-36.

109. Monboisse JC, Rittie L, Lamfarraj H, Garnotel R, Gillery P. In vitro glyoxidation alters the interactions between collagens and human polymorphonuclear leucocytes. Biochem J 2000;350:777-83.

110. Pozo P, Valenzuela MA, Melej C, Zaldivar M, Puente J, Martinez B, Gamonal J. Londitudinal analysis of metalloproteinases, tissue inhibitors of metalloproteinases and clinical parameters in gingival crevicular fluid from periodontitis- affected patients. J Periodontal Res 2005;40:199-207.

111. Garrett IR, Boyce BF, Oreffo ROC, Bonewald L, Poser J, Mundy GR. Oxygenderived free radicals stimulate osteoclastic bone resorption in rodent bone in vitro and in vivo. J Clin Invest 1990;85:632-9.

112. Bax BE, Alam AS, Banerji B, Bax CM, Bevis PJ, Stevens CR et al. Stimulation of osteoclastic bone resorption by hydrogen peroxide. Biochem Biophys Res Commun 1992;183:1153-8. 
113. Hall TJ, Schaeublin M, Jeker H, Fuller K, Chambers TJ. The role of reactive oxygen intermediates in osteoclastic bone resorption. Biochem Biophys Res Commun 1995;207:280-7.

114. Moseley R, Waddington RJ, Embery G. The modification of alveolar bone proteoglycans by reactive species in vitro. Connect Tissue Res 1998;37:13-28.

115. Sculley DV, Langley - Evans SC. Periodontal disease is associated with low antioxidant capacity in whole saliva and evidence of increased protein oxidation. Clin Sci $2003 ; 105 ; 167-72$.

116. Wei PF, Ho KY, Ho YP, Wu YM, Yang YH, Tsai CC.The investigation of glutathione peroxidase, lactoferrin, myeloperoxidase and interleukin-1beta in gingival crevicular fluid: implications for oxidative stress in human periodontal diseases. J Periodontal Res 2004;39:287-93.

117. Greabu M, Totan A, Battino M, Mohora M, Didilescu A, Totan C, Spinu T. Cigarette smoke effect on total salivary antioxidant capacity, salivary glutathione peroxidase and gamma-glutamyltransferase activity. Biofactors 2008;33:129-36

118. Selvam R. Calcium oxalate stone disease: role of lipid peroxidation and antioxidants. Urol Res 2002;30:35-47.

119. Stephens JW, Khanolkar MP, Bain SC. The biological relevance and measurement of plasma markers of oxidative stress in diabetes and cardiovascular disease. Atherosclerosis 2009;202:321-9.

120. Martu I, Luchian I, Goruic A, Checherita L, Martu S, Forna N. Correlations between the periodontal modifications and lipid peroxidation in periodontal disease patients. Rom $\mathbf{J}$ Oral Rehabil 2013;1:26-31. 
121. Karim S, Pratibha PK, Kamath S, Bhat GS, Kamath U, Dutta B, et al. Superoxide dismutase enzyme and thiol antioxidants in gingival crevicular fluid and saliva. J Dent Res 2012;9:266-72.

122. Henskens YM, van den Keijbus PA, Veerman EC, Van der Weijden GA, Timmerman MF, Snoek CM et al. Protein composition of whole and parotid saliva in healthy and periodontitis subjects. Determination of cystatins, albumin, amylase and IgA. J Periodontal Res. 1996;31:57-65.

123. Chapple IL, Brock GR, Milward MR, Ling N, Matthews JB. Compromised GCF total antioxidant capacity in periodontitis: causeor effect? J Clin Periodontol 2007;34:103-10.

124. Chapple ILC, Mason GI, Garner I, Matthews JB, Thorpe GH, Maxwell SRJ, et al. Enhanced chemiluminescent assay for measuring the total antioxidant capacity of serum, saliva and crevicular fluid. Ann Clin Biochem 1997;34:412-21.

125. Kanner J, German JB, Kinsella JE. Initiation of lipid peroxidation in biological system. Crit Rev Food Sci 1987;25: 317-64.

126. Akalın FA, Baltacıog ${ }^{\longleftarrow}$ E, Alver A, Karabulut E. Lipid peroxidation levels and total oxidant status in serum, saliva and gingival crevicular fluid in patients with chronic periodontitis. J Clin Periodontol 2007;34:558-65.

127. Tsai CC, Chen HS, Chen SL, Ho YP, Ho KY, Wu YM, Hung CC. Lipid peroxidation: a possible role in the progression of the chronic periodontitis. J Periodontal Res 2005;40:378-84.

128. Todorović T, Dožić I, Pavlica D, Marković D, Brajović G, Stefanović G, et al. Using of saliva as a diagnostic fluid in dentistry. Srp Arh Celok Lek 2005;133:372-8.

129. Todorović T, Pavlica D, Stefanović G, Dožić I, Brajović G. Saliva - as a dijagnostic fluid. Stom Glas S 2004; 51(2 Suppl):17-29. 
130. Takane M, Sugano N, Ezawa T, Uchiyama T, Ito K. A marker of oxidative stress in saliva: association with periodontally-involved teeth of a hopeless prognosis. J Oral Sci 2005;47:53-7.

131. Konopka T, Król K, Kopeć W, Gerber H. Total antioxidant status and 8-hydroxy-20deoxyguanosine levels in gingival and peripheralblood of periodontitis patients. Arch Immunol Ther Ex 2007;55:1-7.

132. Ekuni D, Tomofuji T, Tamaki N, Sanbe T, Azuma T, Yamanaka R, et al. Mechanical stimulation of gingiva reduces plasma $8-\mathrm{OHdG}$ level in rat periodontitis. Arch Oral Biol 2008;53:324-9.

133. Takane M, Sugano N, Iwasaki H, Iwano Y, Shimizu N, Ito K. New biomarker evidence of oxidative DNA damage in whole saliva from clinically healthy and periodontally diseased individuals. J Periodontol 2002;73:551-4.

134. Rai B, Kharb S, Jain R, Anand SC. Effect of scaling and root planing on salivary 8hydroxydeoxyguanosine: Periodontitis. Inter J Dent Sci 2007;5: number 2.

135. Tamaki N, Tomofuji T, Ekuni D, Yamanaka R, Yamamoto T, Morita M. Short-term effects on non-surgical periodontal treatment on plasma level of reactive oxygen metabolites in patients with chronic periodontitis. J Periodontol 2009;80:901-6.

136. Tomofuji T, Sanbe T, Ekuni D, Azuma T, Irie K, Maruyama T, et al. Oxidative damage of rat liver induced by ligature-induced periodontitis and chronic ethanol consumption. Arch Oral Biol 2008;53:1113-8.

137. Palasciano G, Moshetta A, Palmieri VO, Grattagliano I, Iacobellis G, Portincasa P. Non-alcoholic fatty liver disease in the metabolic syndrome. Curr Pharm Design 2007; 13:2193-8.

138. Albano E. Oxidative mechanisms in the pathogenesis of alcoholic liver disease. Mol Aspects Med 2008;29:9-16. 
139. Ekuni D, Tomofuji T, Sanbe T, Irie K, Azuma T, Maruyama T, et al. Periodontitisinduced lipid peroxidation in rat descending aorta is involvedin initiation of atherosclerosis. J Periodontal Res 2009;44:434-42.

140. Panjamurthy K, Manoharan S, Ramachandran CR. Lipid peroxidation and antioxidant status in patients with periodontitis. Cell Mol Biol Lett 2005;10:255-64.

141. Dhotre PS, Suryaker AN, Bhogade RB. Oxidative stress in periodontitis. Eur J Gen Med 2012;9:81-4.

142. Baltacıoğlu E, Akalın FA, Alver A, Değer O, Karabulut E. Protein carbonyl levels in serum and gingival crevicular fluid in patients with chronic periodontitis. Arch Oral Biol 2008;53:716-22.

143. Silness J, Löe H. Periodontal disease in pregnancy (II). Correlation between oral hygiene and periodontal condition. Acta Odontol Scand 1964;22:121-35.

144. Löe H, Silness P. Periodontal disease in pregnancy I. Acta Odontol Scand 1963;21: 533-51.

145. Saxer UP, Mühlemann HR. Motivation und Aufklarung. Schweiz Monatsschr Zahnmed 1975;85:905-19.

146. Cohen G. Oxidative stress in the nervous system, In: Sies H, editor. Oxidative stress. New York: Academic Press 1995:383-96.

147. Esterbauer H, Wag G, Puhl H. Lipid peroxidation and its role in atherosclerosis. In: Cheesman KH, Slater TF. Free radicals in medicine; Brit Med Bull 1993;49:566-76.

148. Heinecke JW. Oxidative Stress: New approaches to diagnosis and prognosis in atherosclerosis. Am J Cardiol 2003;91(Suppl):12-6.

149. Keith M, Geranmayegan A, Sole MJ, Kurian FR, Robinson A, Omran AS, et al. Increased oxidative stress in patients with congestive heart failure. J Am Coll Cardiol 1998;31:1352-6. 
150. Mantle D, Falkous G, Walker D. Quantification of protease activities in synovial fluid from rheumatoid and osteoarthritis cases: comparison with antioxidant and free radical damage markers. Clin Chim Acta 1999;284:45-58.

151. Memisogullari R, Taysi S, Bakan E, Capoglu I. Antioxidant status and lipid peroxidation in type II diabetes mellitus. Cell Biochem Funct 2003;21:291-6.

152. Kesavulu MM, Rao BK, Giri R, Vijya JS, Subramanyam ACH. Lipid peroxidation and antioxidant enzyme status in type 2 diabetics with coronary heart disease. Diabetes Res Clin Prac 2001;53:33-9.

153. Reznick AZ, Shehadeh N, Shafir Y, Nagler RM. Free radicals related effects and antioxidants in saliva and serum of adolescents with Type 1 diabetes mellitus. Arch Oral Biol 2006;51:640-8.

154. Baynes JW. Role of oxidative stress in development of complications in diabetes. Diabetes 1991;40:405-12.

155. Giulivi C, Romero FJ, Cadenas E. The interaction of Trolox C, a watersoluble vitamin E analog, with ferrylmyoglobin: Reduction of the oxoferrryl moiety. Arch Biochem Biophys 1992;299:302-12.

156. Chan HW-S, Coxon DT. Lipid hydroperoxides. In: Autoxidation of unsaturated lipids. FL: Academic Press, Orlando 1987;17-50.

157. Lagod L, Paszkowski T, Sikorski R, Rola R. The antioxidant-prooxidant balance in pregnancy complicated by spontaneous abortion. Ginekol Pol 2001;72:1073-8.

158. Sun Y. Free radicals, antioxidant enzymes and carcinogenesis. Free Radical Bio Med 1990;8:583-99.

159. Popović V, Lukić V, Perović J, Đukanović D, Gvozdenović Simović V, Beloica D, Vulović M, Dovijanić P, Leković V, Lekić P, Dimitrijević D.Bolesti usta i zuba u stanovništva Beograda. Univerzitet u Beogradu, Stomatološki fakultet, Beograd. 1987. 
160. Brown LJ, Löe H. Prevalence, extent severity and progression of periodontal disease. Periodontol 2000 1993;2:57-71.

161. Peterson PE, Ogawa H. Strengthening the Prevention of Periodontal Disease: The WHO Approach. J Periodontal 2005;76:2187-93.

162. Chapple IL. Reactive oxygen species and antioxidants in inflammatory diseases. J Clin Periodontol 1997;24:287-96.

163. Annil Mahajan A, Tandon V. Antioxidants in rheumatoid arthritis. J Indian Rheumatol Assoc 2004;12:139-42.

164. Čakić S. Gingivalna tečnost u dijagnostikovanju parodontopatije i sistemskih bolesti. Srp Arh Celok Lek 2009;137:298-303.

165. Numabe Y,Hisano A, Kamoi K, Yoshie H, Ito K, Kurihara H. Analysis of saliva for periodontal diagnosis and monitoring. Dent Jap 2004;40:115-9.

166. Mandel ID. The diagnostic uses of saliva. J Oral Pathol Med 1990;3:119-25.

167. Malamud D. Saliva as a diagnostic fluid. Br Med J 1992;305:207-8.

168. Streckfus CF, Bigler LR. Saliva as a diagnostic fluid. Oral Diseases 2002;8:69-76.

169. Cimasoni, G. Monographs in oral science. The crevicular fluid. Basel: Karger,S. 1974;3:156-8.

170. Wei D, Zhang XL, Wang YZ, Yang CX, Chen G. Lipid peroxidation levels, total oxidant status and superoxide dismutase in serum, saliva and gingival crevicular fluid inchronic periodontitis patients before and after periodontal therapy. Aust Dent $\mathbf{J}$ 2010;55:70-8.

171. Dede FO, Ozden FO, Avci B. 8-OHdG levels in gingival crevicular fluid and saliva from patients with chronic periodontitis during initial periodontal treatment. J Periodontol 2013; 84:821-8. 
172. Ibrahem LM. The association between a marker of oxidative stress in saliva and severity of periodontal disease. Med Dent J 2007;4:1-5.

173. Ames B.N. Endogenous oxidative DNA damage, aging and cancer. Free Radic Res Commun 1989;7:121-8.

174. Wu LL, Chiou CC, Chang PY, Wu JT. Urinary 8-OHdG: a marker of oxidative stress to DNA and a risk factor for cancer, atherosclerosis and diabetics. Clin Chim Acta 2004;339:1-9.

175. Akagi S, Nagake Y, Kasahara J, Sarai A, Kihara T, Morimoto H, et al. Significance of 8-hydroxy-2'-deoxyguanosine levels in patients with chronic renal failure. Nephrology (Carlton) 2003;8:192-5.

176. Pilger A, Rudiger HW. 8-hydroxydeoxyguanosine as a marker of oxidative damage related to occupational and environmental exposure. Int Arch Occ Env Hea 2006;8:1-15.

177. Halliwell B. Why and how should we measure oxidative DNA damage in nutritional studies? How far have we come? Am J Clin Nutr 2000; 2:1082-7.

178. Chiou CC, Chang PY, Chan EC, Wu TL, Tsao KC, Wu JT. Urinary 8hydroxydeoxyguanosine and its analogs as DNA marker of oxidative stress: development of an ELISA and measurement in both bladder and prostate cancers. Clin Chim Acta 2003;334:87-94.

179. Canakci CF, Cicek Y, Yildirim A, Sezer U, Canakci A. Increased levels of 8hydroxydeoxyguanosine and malondialdehyde and its relationship with antioxidant enzymes in saliva of periodontitis patients. Eur J Dent 2009;3:100-6.

180. Sezer U, Cicek Y, Canakci CF. Increased salivary levels of 8hydroxydeoxyguanosine may be a marker for disease activity for periodontitis. Dis Markers 2012;32:165-72.

181. Badea V, Balaban DP, Amariei C, Nuca C, Bucur L. Salivary 8-hidroxy-2-deoxy 
guanosine as oxidative stress biomarker for the diagnosis of periodontal disease. Farmacia 2010;58:660-70.

182. Sugano N, Yokoyama K, Oshikaw M, Kumagai K, Takane M, Tanaka H et al. Detection of Streptococcus anginosus and 8-hydroxydeoxyguanosine in saliva. J Oral Sci $2003 ; 45: 181-4$.

183. Canakci CF, Canakci V, Tatar A, Eltas A, Sezer U, Cicek Y et al. Increased salivary level of 8-hydroxydeoxyguanosine is a marker of premature oxidative mitochondrial DNA damage in gingival tissue of patients with periodontitis. Arch Immunol Ther Ex 2009;57: 205-11.

184. Kruidenier L, Verspaget HW. Review article: oxidative stress as a pathogenic factor in inflammatory bowel disease - radicals or ridiculous. Aliment Pharm Ther 2002;16:1997-2015.

185. Buonocore G, Perrone S, Tataranno ML. Oxygen toxicity: chemistry and biology of reactive oxygen species. Semin Fetal Neonat M 2010;15:186-90.

186. Burcham P, Kuhan YT. Introduction of carbonyl groups into proteins by the lipid peroxidation product, malondialdehyde. Biochem Bioph Res Co 1996;220:996-1001.

187. Higueras V, Raya A, Rodrigo JM, Serra MA, Roma J, Romero FJ. Interferon decreases serum lipid peroxidation products of hepatitis C patients. Free Radical Bio Med $1994 ; 15: 131-3$.

188. Jarenlo EJ, Bosch-Morell F, Fernandez-Delgado R, Donat J, Romero FJ. Serum malondialdehyde in HIV seropositive children. Free Radical Bio Med 1998;24:503-6.

189. Al-Rawi NH. Oxidative stress, antioxidant status and lipid profile in the saliva of type 2 diabetics. Diabetes Vasc Dis Re 2011;8:22-8.

190. Gonenc A, Ozkan Y, Torun M, Simsek B. Plasma malondialdehyde (MDA) levels in breast and lung cancer patients. J Clin Pharm Ther 2001;26:141-4. 
191. Bosch-Morell F, Flohe L, Marln N, Romero FJ. 4-Hydroxynonenal inhibits glutathione peroxidase: protection by glutathione. Free Radical Bio Med 1999;26:1383-7.

192. Spitz DR, Malcolm RR, Roberts RJ. Cytotoxicity andmetabolism of 4-hydroxy-2nonenal and 2-nonenal in H2O2-resistant cell lines. Do aldehydic by-products of ipid peroxidation contribute to oxidative stress? Biochem J 1990;267:453-9.

193. Leonarduzzi G, Chiarpotto E, Biasi F, Poli G. 4-Hydroxynonenal and cholesterol oxidation products in atherosclerosis. Mol Nutr Food Res. 2005;49:1044-9.

194. Skrzydlewska E, Sulkowski S, Koda M, Zalewski B, Kanczuga-Koda L, Sulkowska M. Lipid peroxidation and antioxidant status in colorectal cancer. World J Gastroentero 2005;11:403-6.

195. Schmidt H, Grune T, Muller R, Siems WG, Wauer RR. Increased levels of lipid peroxidation products malondialdehyde and 4-hydroxynonenal after perinatal hypoxia. Pediatr Res 1996;40:15-20.

196. Podborska M, Sevcikova A, Trna J, Dite P, Lojek A, Kubala L. Increased markers of oxidative stress in plasma of patients with chronic pancreatitis. Neuroendocrinol Lett 2009;30(Suppl 1):116-20.

197. Lopez O, Bonnefont-Rousselot D, Mollereau M, Olivier R, Montagnier L, Emerit J, et al. Increased plasma thiobarbituric acid-reactive substances (TBARS) before oportunistic infection symptoms in HIV infected individuals. Clin Chim Acta 1996;247:181-7.

198. Armstrong D, Abdella N, Salman A, Miller N, Rahman EA, Bojancyzk M. Relationship of lipid peroxides to diabetic complications. J Diab Comp 1992;6 :116-22.

199. Saygili EI, Konukoglu D, Papila I, Akcay T. Levels of plasma vitamin E, vitamin C, TBARS, and cholesterol in male patients with colorectal tumors. Biochemistry (Moscow) 2003;68:325-8. 
200. Goraca A, Skibska B. Plasma antioksidant status in healty smoking and non-smoking man. Bratisl Med J 2005;106:301-6.

201. Laaksonen DE, Atalay M, Niskanen L, Uusitupa M, Hänninen O, Sen CK. Blood glutathione homeostasis as a determinant of resting and exercise-induced oxidative stress in young men. Redox report: communications in free radical research 1999;4:53-9.

202. Sheikhi M, Bouhafs RK, Hammarstrom KJ, Jarstand C. Lipid peroxidation caused by oxygen radicals from Fusobacterium - stimulated neutrophils as a possible model for the emergence of periodontitis. Oral Dis 2001;7:41-6.

203. Sobaniec H, Sobaniec W, Sendrowski K, Sobaniec S, Pietruska M. Antioxidant activity of blood serum and saliva in patients with periodontal disease treated due to epilepsy. Adv Med Sci 2007;52(Suppl 1):204-6.

204. Triana BG, Pineiro JG, Valle FB, Sotelo PR, Sosa VR, Bernabeu AS. La peroxidation lipidica en la enfermedad periodontal inflamatoria experimental. Rev Cubana Estomatol 1998;35:11-4.

205. Marton IJ, Balla G, Hegedus C, Redi P, Szilagyi Z, Karmazsin L, Kiss C. The role of reactive oxygen intermediates in the pathogenesis of chronic apical periodontitis. Oral Microbiol Immun 1993;8:254-7.

206. Saral Y, Coskun BK, Ozturk P, Karatas F, Ayar A. Assessment of salivary and serum antioxidant vitamins and lipid peroxidation in patients with recurrent aphthous ulceration. Tohoku J Exp Med 2005;206:305-12.

207. Gutteridge JMC. Lipid peroxidation and antioxidants as biomarkers of tissue damage. Clin Chem 1995;41:1819-28.

208. Khalili J, Biloklytska HF. Salivary malondialdehyde levels in clinically healthy and periodontal diseased individuals Oral Dis 2008;14:754-60. 
209. Daković D, Brkić Z, Žunić G. Merenje koncentracije malondialdehida u pljuvački i plazmi obolelih od parodontopatije. Stom Inf 2005;11:7-11.

210. Fulle S, Mecocci P, Fanó G, Vecchiet I, Vecchini A, Racciotti D et al. Specific oxidative alterations in vastus lateralis muscle of patients with the diagnosis of chronic fatigue syndrome. Free Radical Bio Med 2000; 29:1252-9.

211. Surapaneni KM, Venkataramana G. Status of lipid peroxidation, glutathione, ascorbic acid, vitamin E and antioxidant enzymes in patients with osteoarthritis. Indian J Med Sci 2007;61:9-14.

212. Krishna Mohan S, Venkataramana G. Status of lipid peroxidation, glutathione, ascorbic acid, vitamin $\mathrm{E}$ and antioxidant enzymes in patients with pregnancy induced hypertension. Indian J Physiol Pharmacol 2007;51:284-8.

213. Igaru T, Kaneda H, Horiuchi S, Ono S. A remarkable increase of superoxide dismutase activity in synovial fluid of patients with rheumatoid arthritis. Clin Orthop Relat R 1982;162:282-7.

214. Kimura F, Hasegawa G, Obayashi H. Serum extracellular superoxide dismutase in patients with type 2 diabetes. Diabetes Care 2003;26:1246-50.

215. Akalin FA, Toklu E, Renda N. Analysis of superoxide dismutase activity levels in gingiva and gingival crevicular fluid in patients with chronic periodontitis and periodontally healthy controls. J Clin Peridontol 2005;32:238-43.

216. Akalin FA, Is, iksal E, Baltacioglu E, Renda N, Karabulut E. Superoxide dismutase activity in gingiva in type-2 diabetes mellitus patients with chronic periodontitis. Arch Oral Biol 2008;53:44-52.

217. Ellis SD, Tucci MA, Serio FG, Johnson RB. Factors for progression of periodontal diseases. J Oral Pathol Med 1998;27:101-5. 
218. Canakci V, Yildrim A, Canakci CF, Eltas A, Cicek Y, Canakci H. Total antioxidant capacity and antioxidant enzymes in serum, saliva and gingival crevicular fluid of preeclamptic women with and without periodontal disease. J Periodontol 2007;78:160211 .

219. Novakovic N, Todorovic T, Rakic M, Milinkovic I, Dozic I, Jankovic S et al.. Salivary antioxidants as periodontal biomarkers in evaluation of tissue status and treatment outcome. J Periodont Res 2013; doi: 10.1111/jre.12088.

220. Skaleric U, Manthey CM, Mergenhagen SE, Gaspirc B, Wahl SM. Superoxide release and superoxide dismutase expression by human gingival fibroblasts. Eur J Oral Sci 2000;108:130-5.

221. Jacoby BH, Davis WL. The electron microscopic immunolocalization of a copperzinc superoxide dismutase in association with collagen fibers of periodontal soft tissues. J Periodontol 1991;62:413-20.

222. Feres M, Gursky LC, Faveri M, Tsuzuki CO, Figueiredo LC. Clinical and microbiological benefits of strict supragingival plaque control as part of the active phase of periodontal therapy. J Clin Periodontol 2009;36:857-67.

223. Swierkot K, Nonnenmacher CL, Mutters R, Flores-de-Jacoby L, Mengel R. Onestage full-mouth disinfection versus quadrant and full-mouth root planing. J Clin Periodontol 2009;36:240-9.

224. Kim SC, Kim OS, Kim OJ, Kim YJ, Chung HJ. Antioxidant profile of whole saliva after scaling and root planing in periodontal disease. J Periodontal Implant Sci 2010;40:164-71.

225. Sukhtankar L, Kulloli A, Kathariya R, Shetty S. Effect of non-surgical periodontal therapy on superoxide dismutase levels in gingival tissues of chronic periodontitis patients: A clinical and spectophotometric analysis. Dis Markers 2013;34:305-11. 
226. Page RC. The pathobilogy of periodontal diseases may affect systemic diseases: inversion of a paradigm. Ann Periodontol 1998;3:108-20.

227. Fentoglu O, Koroglu BK, Hicyilmaz H et al. Pro-inflammatory cytokine levels in association between periodontal disease and hyperlipidaemia. J Clin Periodontol 2011;38:8-16.

228. Loos BG, Craandijk J, Hoek FJ, Wertheim-van Dillen PM, van der Velden U. Elevation of systemic markers related to cardiovascular diseases in the peripheral blood of periodontitis patients. J Periodontol 2000;71:1528-34.

229. Nakajima T, Honda T, Domon $\mathrm{H}$ et al. Periodontitis-associated up-regulation of systemic inflammatory mediator level may increase the risk of coronary heart disease. $\mathbf{J}$ Periodontal Res 2010;45:116-22.

230. Andrukhov O, Ulm C, Reischl H, Nguyen PQ, Matejka M, Rausch-Fan X. Serum cytokine levels in periodontitis patients in relation to the bacterial load. J Periodontol 2011;82:885-92.

231. Loos BG. Systemic markers of inflammation in periodontitis. J Periodontol 2005;7 :2106 -15.

232. Dave S, Van Dyke TE. Special Review in Periodontal Medicine. The link between periodontal disease and cardiovascular disease is probably inflammation. Oral Dis 2008;14:95-101.

233. Paraskevas, S, Huizinga JD, Loos BG. A systematic review and meta-analyseson Creactive protein in relation to periodontitis. J Clin Periodontol 2008;35:277-90.

234. Janket SJ. Baird AE, Chuang SK, Jones JA. Meta-analysis of periodontal disease and risk of coronary heart disease and stroke. Oral Surg Oral Med O 2003;95:559-69. 
235. Ross R. Aterosclerosis-an inlammatory disease. N Engl J Med 1999;340:115-26.

236. Correa FOB, Gonc salves D, Figueredo CMS, Bastos AS, Gustafsson A, Orrico SRP. Effect of periodontal treatment on metabolic control, systemic inflammation and cytokines in patients with type 2 diabetes. J Clin Periodontol 2010;37:53-8.

237. Taylor GW, Burt BA, Becker MP, Genco RJ, Shlossman M, Knowler WC, et al. Severe periodontitis and risk for poor glycemic control in patients with non-insulin dependent diabetes mellitus. J Periodontol 1996;67:1085-93.

238. Thorstensson H, Kuylenstierna J, Hugoson A. Medical status and complications in relation to periodontal disease experience in insulin-dependent diabetics. $\mathrm{J}$ Clin Periodontol 1996;23:194-202.

239. Kiran M, Arpak N, Ünsal E, Erdogan MF. The effect of improved periodontal health on metabolic control in type 2 diabetes mellitus. J Clin Periodontol 2005;32:266-72.

240. Navarro-Sanchez AB, Faria-Almeida R, Bascones-Martinez A. Effect of non-surgical periodontal therapy on clinical and immunological response and glycaemic control in type 2 diabetic patients with moderate periodontitis. J Clin Periodontol 2007;34:835-43.

241. Montoya-Carralero JS, Saura-Perez M, Canteras-Jordana M, Morata-Murcia IM. Reduction of HbA1c levels following nonsurgical treatment of periodontal disease in type 2 diabetics. Med Oral Patol Oral Cir Bucal 2010;15:808-12.

242. Pararas MV, Skeveki CL, Kafetzis DA. Preterm birth due to maternal infection : causative pathogenes and models of prevention. Eur J Clin Microbiol Infect Disease 2006;25:562-9.

243. León R, Silva N, Ovalle A, Chaparro A, Ahumada A, Gajardo M, et al. Detection of Porphyromonas gingivalis in the amniotic fluid in pregnant women with a diagnosis of threatened premature labor. J Periodontol 2007;78:1249-55. 
244. Katz J, Chegini N, Shiverick KT, Lamont RJ. Localization of P. gingivalis in preterm delivery placenta. J Dent Res 2009;88:575-8.

245. Paju S, Scannapieco F. Special review in periodontal medicine: Oral biofilms, periodontitis, and pulmonary infections. Oral Dis 2007;13:508-12.

246. Routsias JG, Goules JD, Goules A, Charalampakis G, Pikazis D. Autopathogenic correlation of periodontitis and rheumatoid arthritis. Rheumatology 2011;50:1189-93.

247. Tamaki N, Tomofuji T, Ekuni D, Yamanaka R, Morita M. Periodontal treatment decreases plasma oxidized LDL level and oxidative stress. Clin Oral Invest 2011;15:9538.

248. Itabe H. Oxidized phospholipids as a new landmark in atherosclerosis. Prog Lipid Res 1998;37:181-207.

249. Tomofuji T, Ekuni D, Yamanaka R, Kusano H, Azuma T, Sanbe T, et al. Chronic administration of lipopolysaccharide and proteases induces periodontal inflammation and hepatic steatosis in rats. J Periodontol 2007;78:1999-2006.

250. Sobaniec H, Sobaniec-Lotowska ME. Morphological examinations of hard tissues of periodontium and evaluation of selected processes of lipid peroxidation in blood serum of rats in the course of experimental periodontitis. Med Sci Monit 2000:6:875-81.

251. Dhotre PS, Suryakar AN, Bhogade RB. Oxidative stress in periodontitis: A critical link to cardiovascular disease. Biomed Res 2011;22:178-82.

252. Bastos AS, Graves DT, de Melo Loureiro AP, Júnior CR, Abdalla DSP, Faulin TES, et al. Lipid peroxidation is associated with the severity of periodontal disease and local inflammatory markers in patients with type 2 diabetes. J Clin Endocr Metab 2012; 97:1353-62. 
253. Sonoki K, Nakashima S, Takata Y, Naito T, Fujisawa K, Ootsubo T, et al. Decreased lipid peroxidation following periodontal therapy in type 2 diabetic patients. J Periodontol 2006;77:1907-13.

254. Kale R, Samad A, Sumanth S, Baliga S, Khajehnoori M, Muglikar S. Estimation of superoxide dismutase levels in chronic periodontitis patients: A clinical and biochemical study. Univ Res J Dent 2012;2:93-6.

255. Pryor WA, Prier DG, Church DF. Electron-spin resonance study of mainstream and sidestream cigarette smoke: nature of the free radicals in gas-phase smoke and in cigarette tar. Environ Health Persp 1983;47:345-55.

256. Alberg A. The influence of cigarette smoking on circulating concentrations of antioxidant micronutrients. Toxicology 2002;180:121-37.

257. Iho S, Tanaka Y, Takauji R, Kobayashi C, Muramatsu I, Iwasaki H et al. Nicotine induces human neutrophils to produce IL-8 through the generation of peroxynitrite and subsequent activation of NF-кB. J Leukocyte Biol 2003;74:942-51.

258. Calsina G, Ramon J-M, Echeverria JJ. Effects of smoking on periodntal tissues. J Clin Periodontol 2002;29:771-6.

259. Jonsson L, Laovsted S, Zimerman M. Marginal bone loss and tooth loss in a simple from the Country of Stokholm- A longitudinal study over 20 years. Swedish Den J, 2002;26: 21-9.

260. Loft S, Vistisen K, Ewertz M, Tjonneland A, Overvad K, Poulsen HE. Oxidative DNA damage estimated by 8-hydroxydeoxyguanosine excretion in humans: influence of smoking, gender and body mass index. Carcinogenesis 1992;13:2241-7.

261. Li N, Jia X, Chen CYO, Blumberg JB, Song Y, Zhang W, et al. Almond consumption reduces oxidative DNA damage and lipid peroxidation in male smokers $\mathbf{J}$ Nutr 2007;137:2717-22. 
262. Guentsch A, Preshaw PM, Bremer SS, Klinger G, Glockmann E, Sigusch BW. Lipid peroxidation and antioxidant activity in saliva of periodontitis patients: effect of smoking and periodontal treatment. Clin Oral Invest 2008;12:345-52.

263. Garg N, Singh R, Dixit J, Jain A, Tewari V. Levels of lipid peroxides and antioxidants in smokers and nonsmokers. J Periodontal Res 2006;41:405-10.

264. Tonguç MÖ, Öztürk O, Sütçü R, et al. The impact of smoking status on antioxidant enzyme activity and malondialdehyde levels in chronic periodontitis. J Periodontol 2011;82:1320-8.

265. Agnihotri R, Pandurang P, Kamath S, Goyal R, Ballal S. Association of cigarette smoking with superoxide dismutase enzyme levels in subjects with chronic periodontitis. J Periodontol 2009;80:657-62.

266. Yildiz L, Kayaoglu N, Aksoy H. The changes of superoxide dismutase, catalase and glutathione peroxidase activities in erythrocytes of active and passive smokers. Clin Chem Lab Med 2002;40:612-5.

267. Kanehira T, Shibata K, Kashiwazaki H, Inoue N, Morita M. Comparison of antioxidant enzymes in saliva of elderly smokers and non-smokers. Gerodontology $2006 ; 23: 38-42$.

268. Aziz AS, Kalekar MG, Suryakar AN, Benjamin T, Prakashan MJ, Ahmed BMN et al. Assessment of some biochemical oxidative stress markers in male smokers with chronic periodontitis. Ind J Clin Biochem 2013. DOI 10.1007/s12291-012-0283-y.

269. Reejamol MK, Swaminathan M. Estimation of lipid peroxides and antioksidants in smokers and non-smokers with periodontitis. King Saud Univ J Dent Sci 2013;4:53-6. 